\title{
Central America Social Expenditures and Institutional Review
}

\section{EL SALVADOR}

June 29, 2015

Education Global Practice

Health, Nutrition and Population Global Practice

Social Protection and Labor Global Practice

Latin America and the Caribbean Region

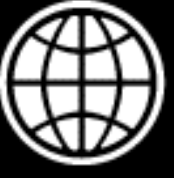

Document of the World Bank 


\section{Table of Contents}

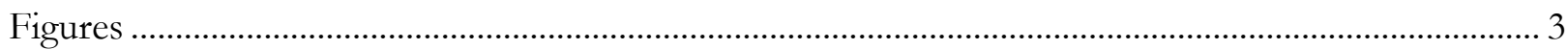

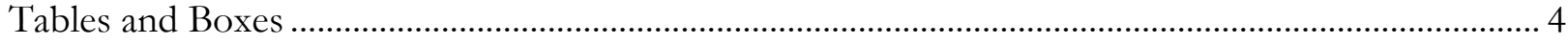

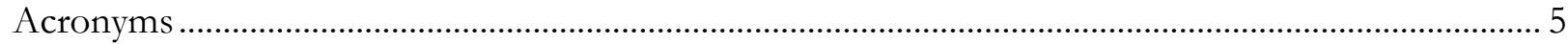

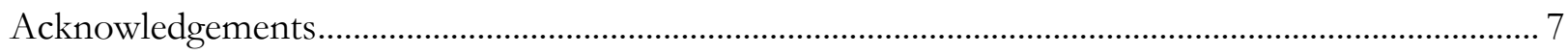

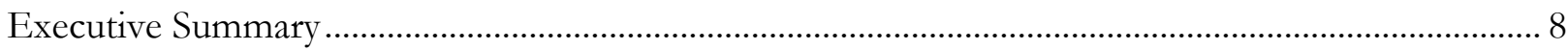

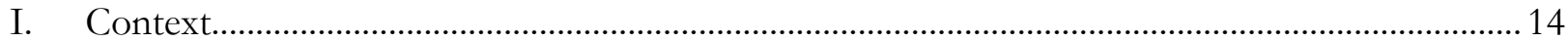

II. Recent Trends in Social Spending in El Salvador................................................................. 17

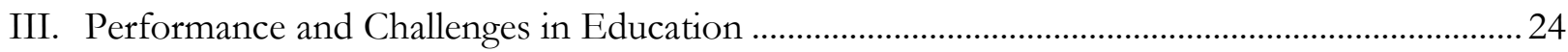

III.1 Recent Evolution of Public Spending on Education ...................................................................2 24

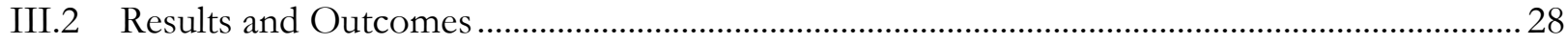

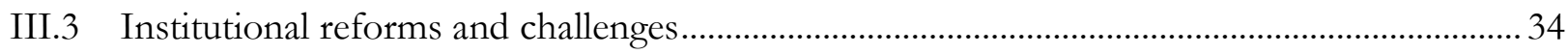

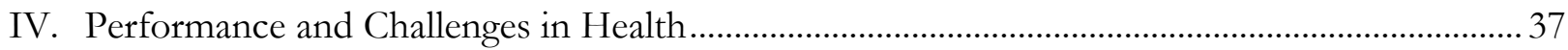

IV.1 Recent Evolution of Public Spending on Health ....................................................................... 37

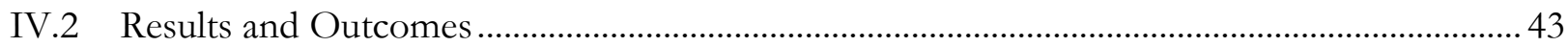

IV.3 Institutional Reforms and Challenges ................................................................................. 47

V. Performance and Challenges in Social Protection and Labor ....................................................... 50

V.1 Recent Evolution of Public Spending on Social Protection and Labor .................................... 50

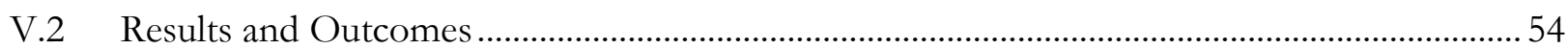

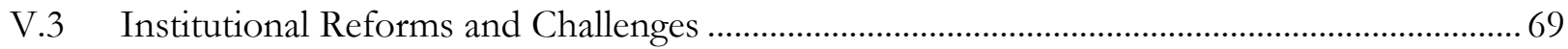

VI. Conclusion and Policy Recommendations ....................................................................................... 71

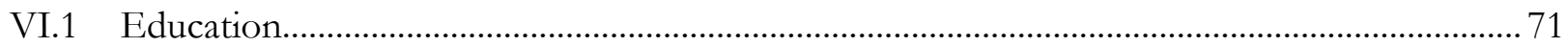

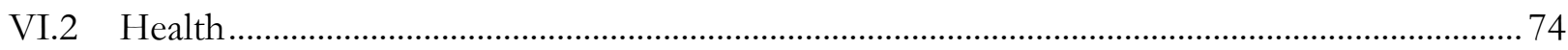

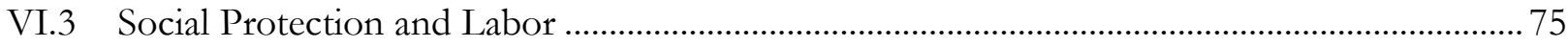

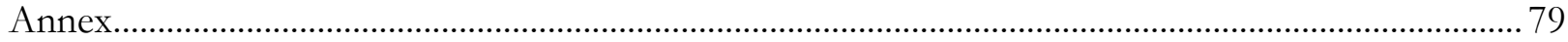

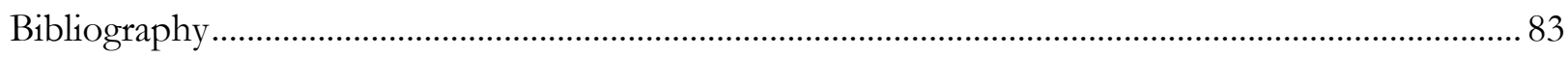




\section{Figures}

Figure 1: GDP growth in El Salvador and Central America, 2001-2013 ..............................................14

Figure 2: Poverty rates in El Salvador, 2005-2013 ................................................................................15

Figure 3: Gini coefficient in El Salvador and other Central American countries ...............................15

Figure 4: Social sector spending in El Salvador, 2007-2013 ................................................................17

Figure 5: Social spending per capita in El Salvador, 2007-2013 ….....................................................18

Figure 6: Social sector spending in El Salvador and other Central American countries, 2013 ...........18

Figure 7: General government overall balance, 2007-2013 ...............................................................19

Figure 8: Revenues of the non-financial public sector, by source (2008-2012, percent of GDP) .......19

Figure 9: Budget execution of social spending, 2007-2013 .....................................................................20

Figure 10: Public Sector Performance and Efficiency in El Salvador and LAC, 2010........................22

Figure 11: Production Possibility Frontier (Data Envelope Analysis) for Social Public Spending, El

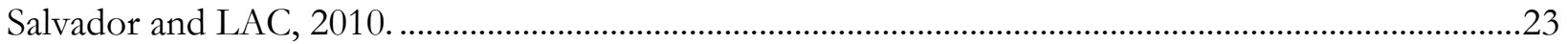

Figure 12: Public spending on education versus GDP per capita (circa 2012)......................................24

Figure 13: Public spending on education as $\%$ of social spending $(\%)$................................................24

Figure 14: Per student public spending on pre-primary and basic education........................................26

Figure 15: Per student public spending on upper secondary education (PPP, US\$ 2007) ..................26

Figure 16: Wage bill as a \% of public education spending by countries $(\%)$.........................................27

Figure 17: Wage bill as a \% of public education spending 2007 and $2013(\%)$.....................................27

Figure 18: Student/teacher ratio and number of teachers .......................................................................28

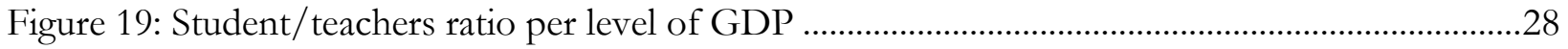

Figure 20: Gross enrollment ratio, upper secondary education vs. GDP per capita (circa 2011) .......29

Figure 21: Attendance rates by location and by age, 2013 ….............................................................30

Figure 22: Proportion of 15-19 years old that completed each grade by area, 2013.............................30

Figure 23: Attendance rates by gender and by age, 2013 ..................................................................30

Figure 24: Proportion of 15-19 years olds that completed each grade by gender, 2013 ........................30

Figure 25: TIMSS 2007 Mathematics 4th grade versus GDP per capita ................................................31

Figure 26: Public spending in education per student in primary (US\$ 2007) .........................................32

Figure 27: Test Results (average scores) …….........................................................................................32

Figure 28: Upper secondary learning outcomes vs per-student spending..............................................32

Figure 29: Public/private enrollment by socio-economic quintile, 2013 ...............................................33

Figure 30: Proportion of 7 year old who can read by quintile, 2013 ......................................................34

Figure 31: Organizational Structure of the FTS Model.........................................................................36

Figure 32: Public Spending on Health as a \% of GDP by countries .....................................................37

Figure 33: Per capita public spending on Health by countries (real, US $\$ 2007$ ) ....................................37

Figure 34: Public, Private, and Out of Pocket expenditure as \% of Total Health Expenditure: 2000

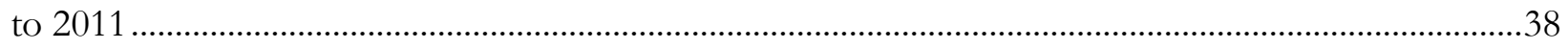

Figure 35: Household Health Expenditure Shares by Health Expenditure Category and by HH

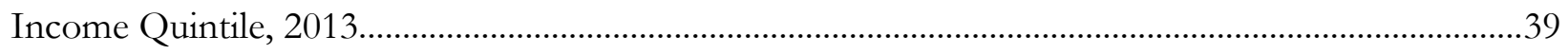

Figure 36: Out-of-pocket spending by expenditure quintile, 2008-2013 ...............................................39

Figure 37: Public expenditure in health by Institution. El Salvador, 2007- 2013 .................................40 
Figure 38: Per capita spending on health by Institution in El Salvador: 2007-2013 ............................41

Figure 39: Health Care visits by level of Care. El Salvador, 2008-2012 .................................................43

Figure 40: Utilization of health facilities by quintile, 2008.................................................................4

Figure 41: Utilization of health facilities by quintiles, 2013 …...........................................................4

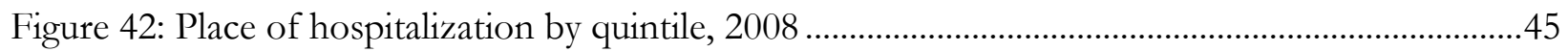

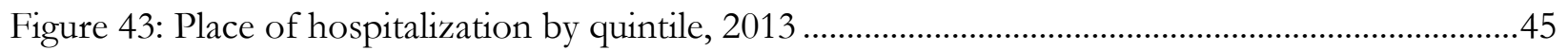

Figure 44: Maternal and child mortality trends, El Salvador 1990-2015 ..............................................46

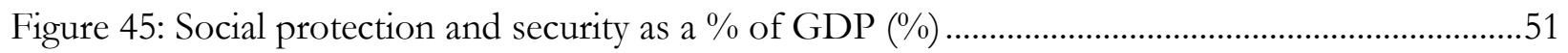

Figure 46: Social protection and security as a \% of Total Public Spending (\%) ...................................51

Figure 47: Social protection and security Per-capita Public Spending (US\$2007) ................................51

Figure 48: Social protection and security as a \% of GDP by country $2012(\%)$....................................52

Figure 49: Social Assistance and Labor spending in El Salvador, 2007-2013 .......................................53

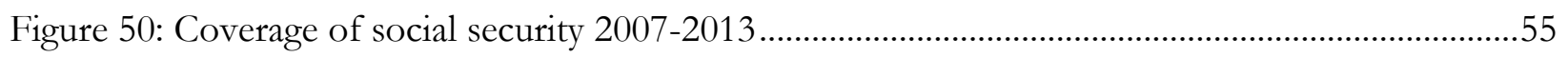

Figure 51: Coverage and Budget of CCT Programs in Latin America ..................................................57

Figure 52: Impact of PATI on labor force participation and incomes. ...............................................57

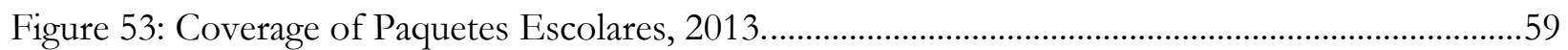

Figure 54: Spending in Electricity and gas (LPG) subsidies, El Salvador, 2007-2013........................60

Figure 55: Beneficiary incidence of major social protection programs in El Salvador, 2013 ...............61

Figure 56: Coverage of CCT and energy subsidies by income quintile, El Salvador 2013 ...................61

Figure 57: Distribution of Benefits of Major Social Assistance Programs (\% of GDP)......................62

Figure 58: Type of Employment by Age Group, El Salvador 2013 .....................................................63

Figure 59: Unemployment rates by age group, El Salvador 2007-2013 ................................................64

Figure 60: Unemployment rates by area of residence, El Salvador 2007-2013 ....................................64

Figure 61: Unemployment rate, by education, El Salvador 2007-2013 ..............................................64

Figure 62: Change in Labor Incomes by Educational Level, 2007-2013 ...............................................65

Figure 63: Firms that Signals "Lack of Appropriate Skills" as the Major Constraint to Growth ........66

Figure 64: Spending of Public Training Institutions in Central America as a \% of GDP, 2013 .........68

Figure 65: Beneficiaries of INSAFORP Training Courses, 2009-2013 …..............................................69

\section{Tables and Boxes}

Table 1: Selected Human Development Indicators, El Salvador, LAC, Central America, and Closest

Income/Population Country Comparators, 2000-2011 ........................................................................16

Table 2: Ministry of Health Expenditures by selected expenditure categories:......................................42

Table 3: Ten most frequent causes of mortality at the MOH Hospitals................................................47

Table 4: Main Social Protection Programs in El Salvador ............................................................................54

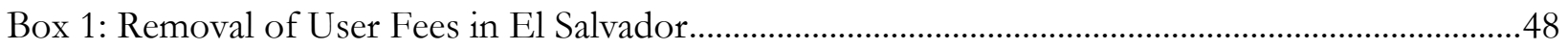

Box 2: Integration of the National Health System in El Salvador: A Future Goal...............................49 
El Salvador Social Expenditure and Institutional Review

\section{Acronyms}

ACE

ADePT

ALMP

CA

CCT

CEPAL

COFOG

COSAM

CSSP

DEA

DNM

ECAP

ECD

ECLAC

ECOS

EDUCO

EHPM

FISDI

FOSALUD

FTS

GDP

GER

GoES

ICEFI

IMF

INSAFORP

ISBM

ISRI
Asociación Comunal para la Educación (Community-Based Association for Education)

World Bank's Software Platform for Automated Economic Analysis

Active Labor Market Program

Central America

Conditional Cash Transfer

Comisión Económica para América Latina (Economic Commission for Latin America)

Classification of the Functions of Government

Comando de Sanidad Militar (Military Health Unit)

Consejo Superior de la Salud Pública (Higher Council for Public Health)

Data Envelope Analysis

Dirección Nacional de Medicamentos (National Directorate of Medicines)

Evaluación de las Competencias Académicas y Pedagógicas (Assessment of Academic and Pedagogical Competencies)

Early Childhood Development

Economic Commission for Latin America

Equipo Comunitario de Salud (Health Community Team)

Educación con Participación de la Comunidad (Education with Community Participation)

Encuesta de Hogares de Propósitos Múltiples (Multiple Purpose Household Survey)

Fondo de Inversión Social y Desarrollo Local (Fund for Social Investment and Local Development)

Fondo Solidario para la Salud (Solidarity Fund for Health)

Full-Time School

Gross Domestic Product

Gross Enrollment Ratio

Government of El Salvador

Instituto Centroamericano de Estudios Fiscales (Central American Institute for Fiscal Studies)

International Monetary Fund

Instituto Salvadoreño de Formación Profesional (Salvadoran Institute for Professional Training)

Instituto Salvadoreño de Bienestar Magisterial (Salvadoran Institute for Teachers' Well-being)

Instituto Salvadoreño de Rebabilitación de Inválidos (Salvadoran Institute for the Rehabilitation of the Handicapped) 
El Salvador Social Expenditure and Institutional Review

ISSS

LAC

MAF

MDG

MINED

MINSAL

MTPS

NCD

ODEI

OECD

ONML

PAES

PAESITA

PATI

$\mathrm{PHC}$

PPP

PSE

PSP

RENACEMPLEO

RIIS

RUP

SAP

SBM

SNFP

SPL

SPP

SPSU

STP

TIMSS

VAT

WB

WDI
Instituto Salvadoreño de Seguridad Social (Salvadoran Institute for Social Security)

Latin American and the Caribbean

MDGs Accelerating Framework

Millennium Development Goal

Ministerio de Educación (Ministry of Education)

Ministerio de Salud (Ministry of Health)

Ministerio de Trabajo y Previsión Social (Ministry of Labor and Social Security)

Non-communicable disease

Organismo Directivo de la Escuela Inclusiva (Inclusive School Executive Board)

Organisation for Economic Co-operation and Development

Observatorio Nacional del Mercado Laboral (National Labor Market Observatory)

Prueba de Aprendizajes y Aptitudes para Egresados de Educación Media (National Assessment of Learning Competencies for Secondary School Graduates)

Prueba de Aprendizajes y Aptitudes para Egresados de Educación Básica (National Assessment of Learning Competencies for Basis Education Graduates)

Programa de Apoyo Temporal al Ingreso (Temporary Income Support Program)

Primary Health Care

Purchasing Power Parity

Public Sector Efficiency

Public Sector Performance

Red Nacional
Opportunities)

Red Integral e Integrada de Servicios de Salud (Comprehensive and Integrated Health Services Network)

Registro Único de Participantes (Consolidated Database of Program Participants)

Sistema de Ahorro para Pensiones (Pension Fund System)

School-Based Management

Sistema Nacional de Formación Profesional (National System for Professional Training)

Social Protection and Labor

Sistema Público de Pensiones (Public Pension System)

Sistema de Protección Social Universal (Universal Social Protection System)

Secretaría Técnica de la Presidencia (Technical Secretariat of the Presidency)

Trends in Mathematics and Science Study

Value-Added Tax

The World Bank Group

World Development Indicators 


\section{Acknowledgements}

This country note was prepared by a team led by Pablo Acosta, Rita Almeida, Christine Lao Peña and Juan Diego Alonso. It also comprised Pablo Alfaro Palominos, Ciro Avitabile, Nancy Banegas Raudales, Eleonora Cavagnero, Amparo Gordillo-Tobar, Emma Monsalve Montiel, Christopher Wahoff and Evan Sloane Seeley, under the overall coordination of Kathy Lindert, as part of the Central America Social Sector Expenditure and Institutional Review. We would like to thank Mansoora Rashid, Reema Nayar, Joana Godinho, Margaret Grosh, and Fabrizio Zarcone for their guidance, comments, and support in the elaboration of this note. 


\section{Executive Summary}

\section{Social Spending: In the quest for improving social indicators in a fiscally constrained environment for social spending}

El Salvador's development over the past decade has been dichotomous. On the one hand, economic growth has remained persistently low, employment and labor force participation have barely increased, and progress on poverty reduction has slowed. On the other hand, inequality has fallen, and shared prosperity improved together with advances in many social indicators, such as pre-primary enrollment rates, access to prenatal care, immunizations, and water and sanitation. The increase in the use of social spending, which now accounts for 12.4 percent of GDP, together with an improvement in the quality of social spending, explain at least part of this dichotomy of redistributive and social gains despite low growth, a tight fiscal situation and generally low government revenues and spending.

Looking forward, the key challenges El Salvador faces are related to continuing improving the quality and efficiency in the social sectors, while maintaining the overall level of social spending within an increasingly constrained fiscal environment, where fiscal constraints, low revenues, and the need to cut the deficit by 3 percent of GDP are significant elements, as well. Priority would have to be given to reallocations and improvements within the spending envelope for the social sectors to maximize impact. This document analyzes social spending for El Salvador for the education, health and social protection and labor sectors in depth and explores a series of policy options for El Salvador to reallocate social spending for more effective impacts, to enhance and reform social policies and social service delivery, and to improve the management of public spending and budget execution in the social sectors.

\section{Education: Low education spending good enough for ensuring universal access to primary education, but large gaps still remain both in access (to all other levels) and in the quality of learning}

Public spending on education in El Salvador has been steadily growing but remains low relative to other countries in the region and by international standards. In 2013, El Salvador's public spending on education accounted for 3.6 percent of the Gross Domestic Product (GDP), which is lower than the average for the Latin America and the Caribbean (LAC) (4.9 percent) and pales in comparison to the average for the Organisation for Economic Co-operation and Development (OECD) (5.6 percent). A disproportionally high share of public spending in education (68 percent) still goes to basic education.

El Salvador has achieved the Millennium Development Goal (MDG) of universal primary education, but the enrollment rates for other levels of education and the quality of the learning across the board are still low. The gross enrollment rate in upper secondary education in 2012 was 48 percent, the lowest in the Central America (CA) region. Similarly, international comparisons show that the quality of learning is lower than countries with similar levels of GDP. The increase in public spending on education has improved access both in primary and secondary education, but it has not translated into improvements in learning outcomes. Within-country inequalities -across income levels, geographic 


\section{El Salvador Social Expenditure and Institutional Review}

locations, and types of schools - also reveal important disparities across different groups both in access and learning, contributing to the persistency of inequality for future generations in the country.

Looking forward, policy would have to focus on improving access and reducing inequalities to preprimary and secondary education. On the one hand, El Salvador should ensure continuity within the new full-time school model currently being rolled out. On the other hand, more efforts should be placed in assessing why children are dropping out from secondary education, along with issues related to crime and violence that affect that age group. Although high opportunity costs of attending a secondary school are likely to play a role, a more thorough diagnostic is needed, especially for the most vulnerable groups. Linking upper secondary school attendance to the conditionalities of the CCT program could also be piloted and evaluated. This intervention might be piloted in urban areas, where school supply is less problematic, and it might be funded either by reducing the transfer component for primary school attendance or through better targeted consumption subsidies.

Given disparities in school readiness, a comprehensive Early Childhood Development (ECD) strategy is a necessary condition to improve learning outcomes in the medium/long run, whereas an increase in the number and quality of teachers at primary and secondary education is likely to have a positive impact in the shorter term. In spite of the recent improvements, the student-teacher ratio is still too high and more teachers are needed in traditional and new subjects (such as music/art that are emphasized in the full-time schools model). The need to hire new teachers, due to the implementation of the full-time school model, provides El Salvador with a unique opportunity to improve the average quality of its teacher corps through an improvement in the selection and recruiting methods. Despite the relatively competitive level of teacher wages, creating special financial incentives to attract top students to the teaching profession and raising accreditation standards for university-based programs are promising and viable strategies to complement the wage bill efforts. In addition, policies improving parental ability to provide feedback to teachers and bonus payments for teachers would likely produce substantial effects on overall teacher motivation and, therefore, could be further studied and supported.

Finally, the monitoring and evaluation of education policies require a stronger focus, producing "real time" information that ideally feeds directly into government design and implementation. Even though El Salvador has rich data sets, serious gaps remain in the monitoring and evaluation system utilized within the Ministry of Education (MINED). There is room to ensure that the policy implementation and decision making in the education system is better informed. For instance, a more efficient and timely use of the existing information could yield significant insights and results to guide decision-making at different policy levels. Given the lack of relevant training and a policy of information dissemination, principals and teachers are unable to effectively use the data obtained through the standardized test scores. Those gaps highlighted present an important and necessary opportunity for the modernization of MINED's information systems, specifically related to monitoring and evaluation. 
Health: Increase in public spending on health along with the free-access-tohealth-care policy increased the use of health care and contributed to improving coverage and results, but access and quality disparities remain

Public spending on health in El Salvador has increased over time and is more or less in line with most CA countries. Despite the economic crisis, the Government of El Salvador (GoES) protected public health spending, and real per capita public expenditures on health even slightly increased between 2007 and 2013.

The increase in public spending on health together with the Government's free health care policy services resulted in a decrease in private out-of-pocket spending and an increase in the use of health care services. By 2013, out-of-pocket expenses by households were mainly focused on medicines and other health spending such as glasses rather than the cost of health services. Although, the free health care policy implemented in El Salvador positively influenced the use of public health services for consultations and hospitalizations among households at all quintile levels, approximately 46 percent of people in the poorest income quintile who reported being sick still did not seek health care in 2013.

As a result of the Government's efforts to protect and increase public spending on health and improve coverage, health outcomes have improved since the 1990s. In particular, child and maternal mortality rates have decreased. El Salvador is the only CA country that has achieved its MDG 4 (under-five mortality) target before 2015.

However, challenges remain in improving results and addressing disparities in the quality of health care. The relatively high neonatal mortality and maternal mortality rates (MDG 5) suggest that although institutional birth deliveries have increased (now at 85 percent of all births), the quality of care still needs to be improved. The average mortality and infant mortality rates also hide significant disparities within the country, which in turn, reflect disparities in the distribution of resources, coverage and the quality of health care provided between urban and rural areas. Chronic noncommunicable diseases (NCDs) have also increased, requiring a more comprehensive and multisectoral strategy aside from the country's Maternal and Child Health-focused strategy.

In terms of institutional aspects, the Government has strengthened the health sector with a new national strategy and a commitment to meet MDG 5. The Government has developed a National Health Strategy which has been partially implemented over the past four years. This strategy seeks to strengthen the provision of free health care, emphasizing comprehensive primary health care (PHC) and human rights under the Comprehensive and Integrated Health Services Network (RIIS). The Government has also committed to achieving MDG5 by signing on to the MDGs Accelerating Framework (MAF) supported by the United Nation Agencies and the World Bank. While the Health Community Teams (ECOS) program is an innovative program that provides PHC to vulnerable areas via mobile teams, it raises some question of sustainability since it is currently funded from international donors. Moreover despite the Government's intentions to unify the public provision of health services, health care continues to be provided by several institutions with different packages of services and different per capita health expenditures. 
Looking forward, in addition to the implementation of the MAF program to accelerate progress on the MDGs, the Government could consider short-term measures such as: (a) revising its planning and budgetary processes in order to make them more results-oriented and efficient; (b) revising the RIIS strategy and the sustainability of the ECOS; (c) improving targeting strategies, including epidemiological and geographical targeting, to reach the poorest households and encourage them to seek health care in a timely manner; (d) developing a strategy to effectively incorporate NCDs in its PHC program; and (e) review and assess the potential for reducing the differential per-capita expenditures in the national public system, taking into account political economy and socio-economic factors. In the medium term, the Government could: (a) move from historical budgeting to a resultbased allocation mechanism, (b) redefine aspects of the RIIS-ECOS programs and strengthen their implementation; (c) implement an approved NCD strategy at the PHC level; and (d) based on the review, develop a strategy to promote and move toward reducing disparities in health packages and per capita spending across institutions and integrating the National Health System.

\section{Social Protection: Expanded safety net but through inefficient and poorly targeted subsidies, which need to be reformed to guarantee sustainability}

El Salvador has made commendable efforts in expanding social protection and labor (SPL) coverage and spending since 2009, from a low base to levels more in the range of regional standards. Overall SPL spending has increased in recent years, from 3.5 to 5 percent of GDP between 2007 and 2013. Taken as a whole, SPL spending is still on the lower range in regional terms. However, today El Salvador allocates the highest share of GDP to social assistance - primarily via subsidies-- in the CA region.

El Salvador's rural CCT program (Comunidades Solidarias Rurales), launched in 2005, is well-targeted to the poor and has a proven track record of impact in poverty and social indicators. However, the coverage of the program remains low and has even declined in recent years - alongside the expansion in outlays on untargeted subsidies. Reforms of the CCT could revise the menu of benefits, and expand the program to urban areas where many of the poor live. During the previous administration, efforts to incentivize school attendance were concentrated on the provision of school uniforms rather than on cash transfers, but no evaluation on whether this CCT mechanism was effective was undertaken. In urban areas, the main intervention is a "workfare" program - known as the Temporary Income Support Program (PATI) - that combines income support with training, and that it is proving an effective way to increase employability prospects of vulnerable population. Due to the positive results from impact evaluations, it would be expected for this program to be maintained as it provides opportunities for income and human capital development for the poor, while at the same time stimulates economic activity at the local level.

Reallocation of scarce resources to maximize coverage and impact on poverty reduction is essential. Current fiscal constraints make it imperative to improve targeting and efficiency of SPL spending. High leakages to non-poor beneficiaries within and across social assistance and subsidies, coupled with insufficient coverage among the extreme poor, diminish the impact of social assistance programs: at 


\section{El Salvador Social Expenditure and Institutional Review}

least 0.6-0.7 percent of GDP (\$160 million) is spent on benefits from social assistance and subsidies that go to families in the highest quintiles. While the well-targeted CCT program covers barely 11.6 percent of extreme poor families, nearly 70 percent of the richest families receive Government electricity and gas subsidies. A simple reform that excludes from subsidies those consuming between 100 and 200 kilowatts/hour of electricity would save 0.45 percent of GDP that could be reallocated to expand pro-poor programs.

Social security reforms are pending, since coverage has been stuck at around 30 percent for the past decade, and the system creates unsustainable deficits. Attempts to increase coverage among the poor have not succeeded, and the building blocks for a social pension are still at a piloting stage given insufficient funding. More worrisome, the previous reform to the contributory system introduced important "transition costs", which are now in the order of 2 percent of GDP. The new administration should tackle social security reform as a high priority on fiscal and equity grounds.

A large majority of the population has persistent employability challenges, with difficulties in retaining a formal job. However, coverage of active labor market programs (ALMPs) is low, and it is not necessarily benefiting priority groups. Experiences like PATI are promising, but would need to be complemented with appropriate interventions to improve human capital, productivity, and better skills match with local employment opportunities to ensure sustained income generation of the vulnerable population. In general, ALMPs operate on a very small scale in El Salvador (for example, there is no national youth employment program, as in many other LAC countries), and resources in strengthening employment offices for labor intermediation and orientation are insufficient. Nevertheless, there are important resources allocated to training, but the majority of courses benefits high-skilled employed population. The current institutional setting for the occupational training system provides little information on the quality and adequacy of existing training programs, limiting the efforts of better matching existing skills and those needed in the market.

The past Government administration made substantial efforts to build a Universal Social Protection System (SPSU) as part of its National Development Plan. The mandate of the SPSU implies an integral reform concerning the way in which the social development policies of the Government are coordinated, administered and implemented starting with the ruling entities of the Executive power. However, the lack of a single "champion ministry" in charge of defining policy and implementing interventions (a so-called "Ministry of Social Development") makes this coordination a complex task, impacting in the effective achievement of goals.

Legislation could help to protect gains in expanding SPL, but it needs to be flexible enough to adapt to changing needs, reflect fiscal realities, and generate consensus. The Salvadoran Congress recently approved a new Law of Social Development and Social Protection (April, 2014), aiming to provide a minimum social protection floor for all the population and protect rights, as stated in the SPSU strategy. However, the new Law does not address the fiscal angle or the institutionality needed for its implementation; and a consultation process with all relevant stakeholders has not yet taken place. The new Law misses the need for continuous monitoring and evaluation of programs, with a focus on 


\section{El Salvador Social Expenditure and Institutional Review}

improving impact within the fiscal space already gained. Enhanced implementation requires deep reflection on the fragmentation of programs and their financing.

The Government is also creating a registry of beneficiaries of social program (RUP) that will help to avoid duplication of beneficiaries and improve targeting of social programs. However, this effort would require additional resources to finalize the data collection and technology platform, as well as a mandated commitment on its coordinated use by different agencies executing programs (an opportunity to include in the new social protection legislation). The past administration has also advanced the development of a system to track indicators in the social sector that can guide in the future the planning and budgeting process. It also emphasized the need to evaluate its interventions, and has done that with PATI, ECOS community health, School Uniforms program, and the social pension, to make corrections as needed. These efforts would need to be continued and expanded in the current administration. 


\section{Context}

Over the last decade, El Salvador experienced a persistently low economic growth, which led to an even lower growth in per capita income levels. In the 2001-2013 period, El Salvador's economy grew on average 2 percent per year, which was less than half the average for the remaining countries in the CA region (Figure 1). In addition, since 2003, El Salvador has been consistently the lowest performer in the region in terms of growth. ${ }^{1}$ Growth rates remained stable between 2001 and 2004, oscillating between 1.7 and 2.3 percent, and later between 2005 and 2007, between 3.6 percent and 3.9 percent. However, in 2009, a combination of the global financial crisis and other factors led to an important decline in GDP of -3.1 percent. Recovery did not place growth at pre-crisis levels, reaching between 1.4 and 2.2 percent from 2010 to 2013. As a consequence, GDP per-capita grew only 1.4 percent on average between 2000 and 2013, placing El Salvador again as the lowest performer of the CA region. Although El Salvador continues to be the third country, behind Panama and Costa Rica, in terms of GDP per capita, the aforementioned countries have widened the gap with El Salvador since 2000.

Figure 1: GDP growth in El Salvador and Central America, 2001-2013

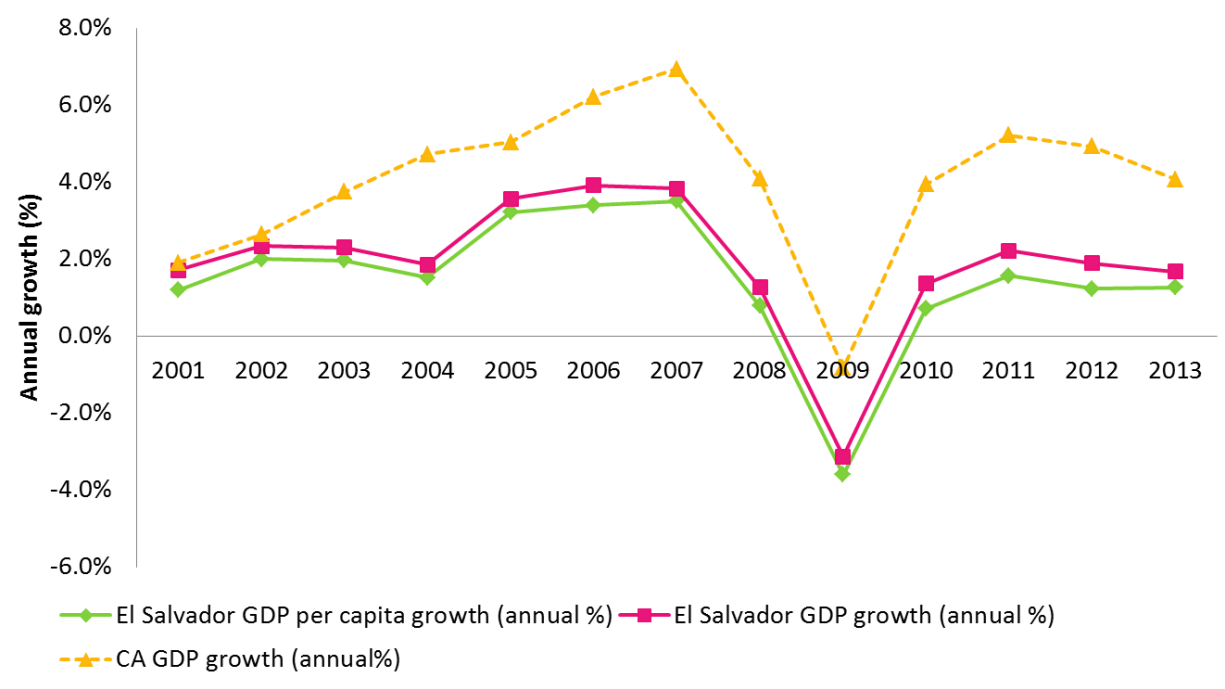

Source: IMF, World Economic Outlook Database, October 2014

Despite the low rates of economic growth, El Salvador achieved a significant reduction in both poverty and inequality rates. The number of people below the poverty line reached a historical low in 2013 when, for the first time ever, less than 30 percent of Salvadorans were below the poverty line. Concomitantly, the percentage of the population considered extreme poor also

\footnotetext{
${ }^{1}$ Except for 2005, when El Salvador outpaced Guatemala.
} 
reached a historical low of 7.1 percent (Figure 2). In the same vein, inequality rates showed continuous progress: the Gini coefficient fell from 0.51 (2000-05) to 0.45 in 2013. This level of inequality in the distribution of income places El Salvador as the country with the lowest inequality level in Central America, followed by Nicaragua with 0.46 (2009), Costa Rica and Panama both with 0.53 (2013), Guatemala with 0.54 (2011) and Honduras with 0.54 (2013) (Figure 3).

Figure 2: Poverty rates in El Salvador, 2005-2013

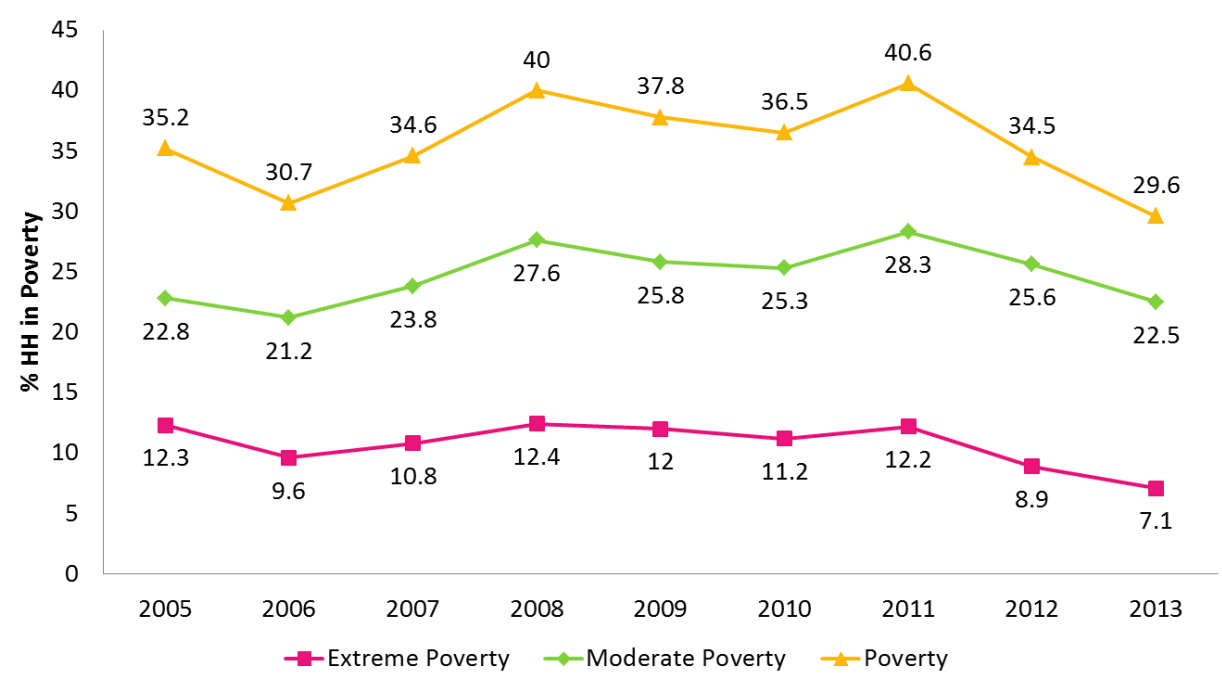

Source: Digestyc

Figure 3: Gini coefficient in El Salvador and other Central American countries

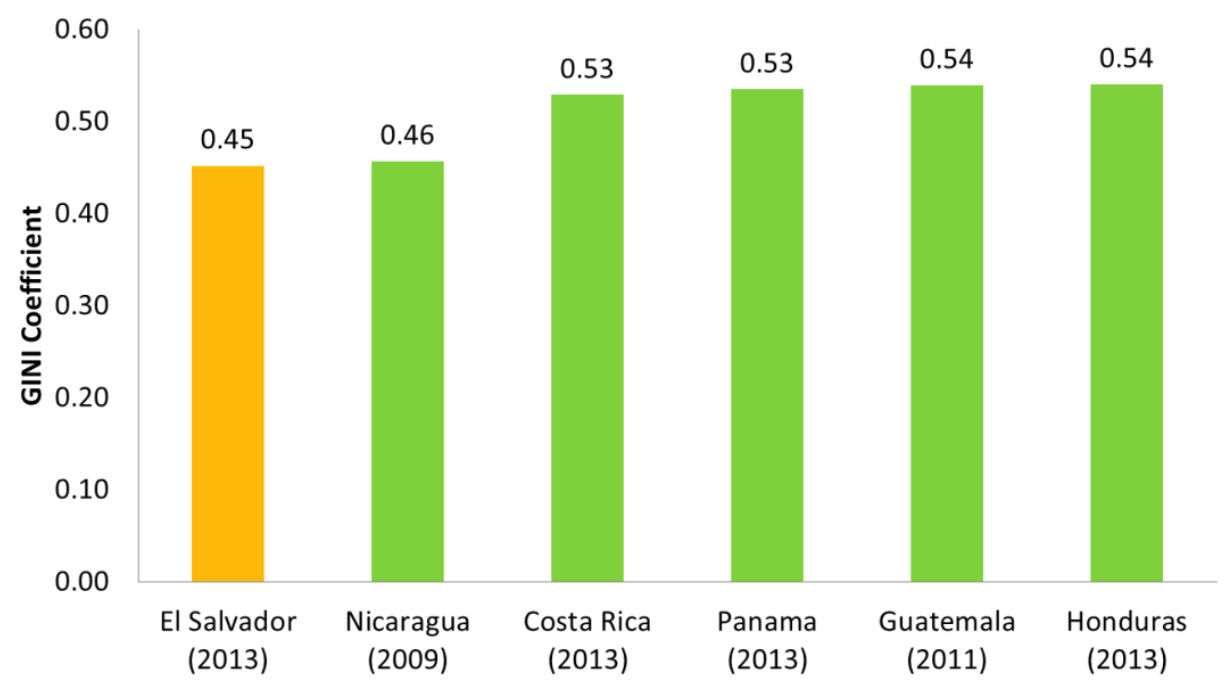

Source: World Bank team's analysis of household surveys and calculations using standardized ADePT software (Social Protection).

In addition to the significant reduction in poverty and inequality rates, El Salvador has made important progress in several human development indicators over the past decade. Table 1 
compares El Salvador's evolution of selected indicators in the areas of education, health and nutrition, and social protection and poverty with three groups of comparators: i) the top 7 economies in the LAC region; ii) the remaining countries in the CA region; and iii) a set of 8 countries around the world that can be considered "comparator countries" when judged after a series of criteria (see Table note). In order to show progress, the 12-year period (2000-2011) was split in two 6-year intervals (2000-2005 and 2006-2011). El Salvador shows a consistent trend of improvement in social indicators across the board, anywhere from pre-primary enrollment rates, to access to prenatal care, immunizations, and water and sanitation. However, on average, progress occurred at a slower pace compared to any of the three comparator groups. Analyzing the within-sector indicators, differential rates of progress are also observable. In education, pre-primary enrollment rates increased significantly, but secondary and tertiary enrollment rates have advanced at a much slower pace. Health indicators related to prenatal care, immunizations, and access to water and sanitation have all improved, though under-nutrition rates increased slightly. Finally, in terms of social protection and poverty, it is noticeable that although both poverty and inequality made significant progress, this did not translate into similar-sized improvements in labor market indicators.

Table 1: Selected Human Development Indicators, E1 Salvador, LAC, Central America, and Closest Income/Population Country Comparators, 2000-2011

\begin{tabular}{|c|c|c|c|c|c|c|c|c|}
\hline \multirow{2}{*}{ Indicator Name } & \multicolumn{2}{|c|}{\begin{tabular}{|c|} 
El Salvador \\
\end{tabular}} & \multicolumn{2}{|c|}{$\mathrm{LAC}_{7 *}$} & \multicolumn{2}{|c|}{ Avg. Rest of CA } & \multicolumn{2}{|c|}{ Closest Comparators** } \\
\hline & \multicolumn{2}{|c|}{ 2000-2005 2006-2011 } & \multicolumn{2}{|c|}{ 2000-2005 2006-2011 } & \multicolumn{2}{|c|}{ 2000-2005 2006-2011 } & \multicolumn{2}{|c|}{$2000-2005$ 2006-2011 } \\
\hline \multicolumn{9}{|l|}{ Education } \\
\hline School enrollment, preprimary (\% gross) & 49.8 & 60.2 & 66.1 & 82.2 & 46.6 & 59.2 & 38.3 & 44.2 \\
\hline School enrollment, primary (\% gross) & 109.1 & 114.4 & 113.2 & 113.2 & 110.1 & 113.9 & 106.2 & 105.4 \\
\hline School enrollment, secondary (\% gross) & 58.6 & 63.5 & 79.1 & 86.5 & 61.4 & 71.9 & $79 \cdot 5$ & 89.0 \\
\hline School enrollment, tertiary (\% gross) & 20.8 & 22.5 & 30.7 & $45 \cdot 3$ & 22.7 & 31.3 & 24.8 & 33.0 \\
\hline Primary completion rate, total (\%) & 82.9 & 92.3 & 99.1 & 103.7 & 81.1 & 89.1 & 97.1 & 94.4 \\
\hline Pupil-teacher ratio, primary & 45.0 & $34 \cdot 7$ & 24.8 & 23.0 & $29 \cdot 4$ & 26.8 & 21.1 & 18.1 \\
\hline \multicolumn{9}{|l|}{ Health } \\
\hline Pregnant women with prenatal care (\%) & 86.0 & 94.0 & 92.2 & 96.0 & 86.0 & 92.3 & 96.0 & 98.1 \\
\hline Undernourishment (\% of pop) & 9.9 & 11.8 & 11.7 & 9.6 & 20.3 & 15.9 & 9.6 & 8.6 \\
\hline Immunization, measles (\% 12-23 m) & $94 \cdot 5$ & 94.7 & 94.9 & 94.9 & 92.9 & 94.1 & 91.4 & $95 \cdot 5$ \\
\hline Improved sanitation facilities ( $\%$ of pop) & 84.0 & 86.6 & 80.4 & 83.5 & 70.4 & 73.6 & 87.1 & 89.5 \\
\hline Improved water source (\% of pop) & 84.0 & 87.0 & 91.4 & 93.4 & 88.1 & 90.4 & 91.3 & 92.2 \\
\hline Hospital beds (per 1,00o people) & 0.9 & 0.9 & 2.0 & 2.1 & 1.3 & 1.1 & 3.2 & 2.9 \\
\hline \multicolumn{9}{|l|}{ Social Protection and Poverty } \\
\hline Employment to population ratio, $15^{+},(\%)$ & 55.8 & 57.1 & 58.3 & 60.6 & 58.3 & 60.8 & 46.4 & 46.5 \\
\hline Labor force participation rate, female (\%) & 47.6 & 49.6 & 52.8 & 56.1 & 44.8 & 48.3 & $44 \cdot 7$ & 44.6 \\
\hline Unemployment, total $(\%)$ & 6.8 & 6.5 & 9.8 & 7.8 & 6.8 & 4.5 & 20.0 & 18.4 \\
\hline GINI index & 51.4 & 47.1 & $54 \cdot 5$ & 51.5 & 52.1 & 54.1 & 38.6 & 35.8 \\
\hline Poverty headcount ratio, rural (\%) & 47.8 & 35.8 & $55 \cdot 3$ & 47.6 & 63.6 & 58.0 & 32.5 & 26.3 \\
\hline Poverty headcount ratio, urban (\%) & 30.2 & 27.7 & 37.6 & 26.0 & $33 \cdot 3$ & 31.2 & 24.7 & $15 \cdot 7$ \\
\hline
\end{tabular}




\section{Recent Trends in Social Spending in El Salvador}

Social spending has been increasing in E1 Salvador, and is likely an important contributor to the redistributive and social gains noted above, despite fiscal constraints and low growth. Between 2007 and 2013, social spending increased from 9.7 percent to 12.8 percent of GDP (Figure 4). This significant increase in the proportion of public expenditure devoted to social programs was driven by an average growth rate of 5 percent per year. Most notably, even during the economic crisis of 2009, when El Salvador's GDP decreased 3.1 percent, social spending increased both in real terms and as a percentage of GDP. Moreover, social spending as a percentage of total spending increased from 35.3 percent in 2007 to 40.1 percent in 2013.

Figure 4: Social sector spending in El Salvador, 2007-2013

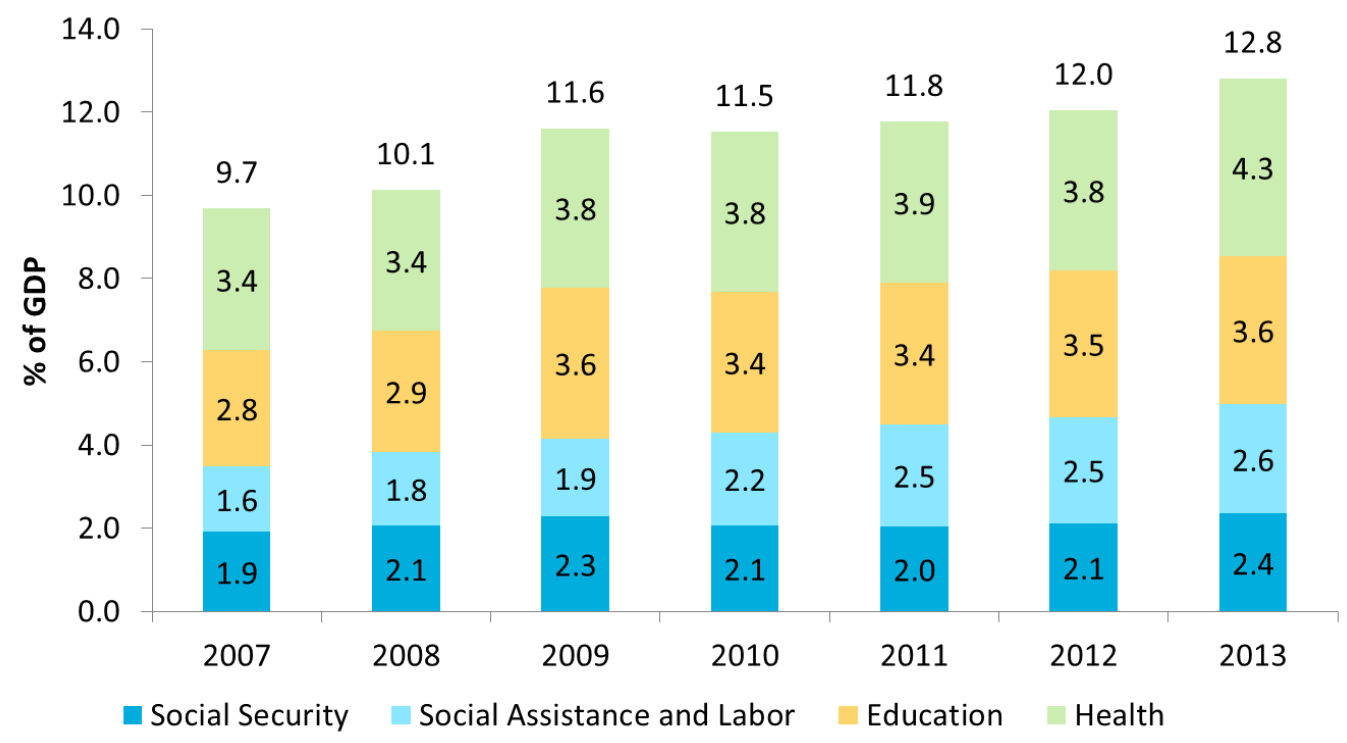

Source: World Bank's calculations from ICEFI social spending database

Interestingly, although public spending as a proportion of the GDP increased significantly in the last years, the allocation across the three main social sectors (education, health $\&$ nutrition, and SPL) remained fairly stable. In 2013, SPL (including social security and subsidies) accounted for the largest portion of social spending, 5 percent of GDP, followed by health (4.3 percent), and education (3.6 percent) (Figure 4). Looking at the shares of social spending, proportions among sectors remained very stable between 2007 and 2013, with education remaining at 29 percent, and SPL (36 percent in 2007 versus 39 percent in 2013) gaining a little space over health, (35 percent in 2007 versus 33 percent in 2013).

In real terms, social spending per capita increased significantly between 2007 and 2013. Overall social spending per capita increased from US\$674 to US\$846 in real terms, representing an annual average increase of 3.9 percent (Figure 5). Health increased only 2.9 percent, below the overall growth rate, while education increased 3.3 percent and SPL 5.2 percent annually. 
El Salvador Social Expenditure and Institutional Review

Figure 5: Social spending per capita in E1 Salvador, 2007-2013

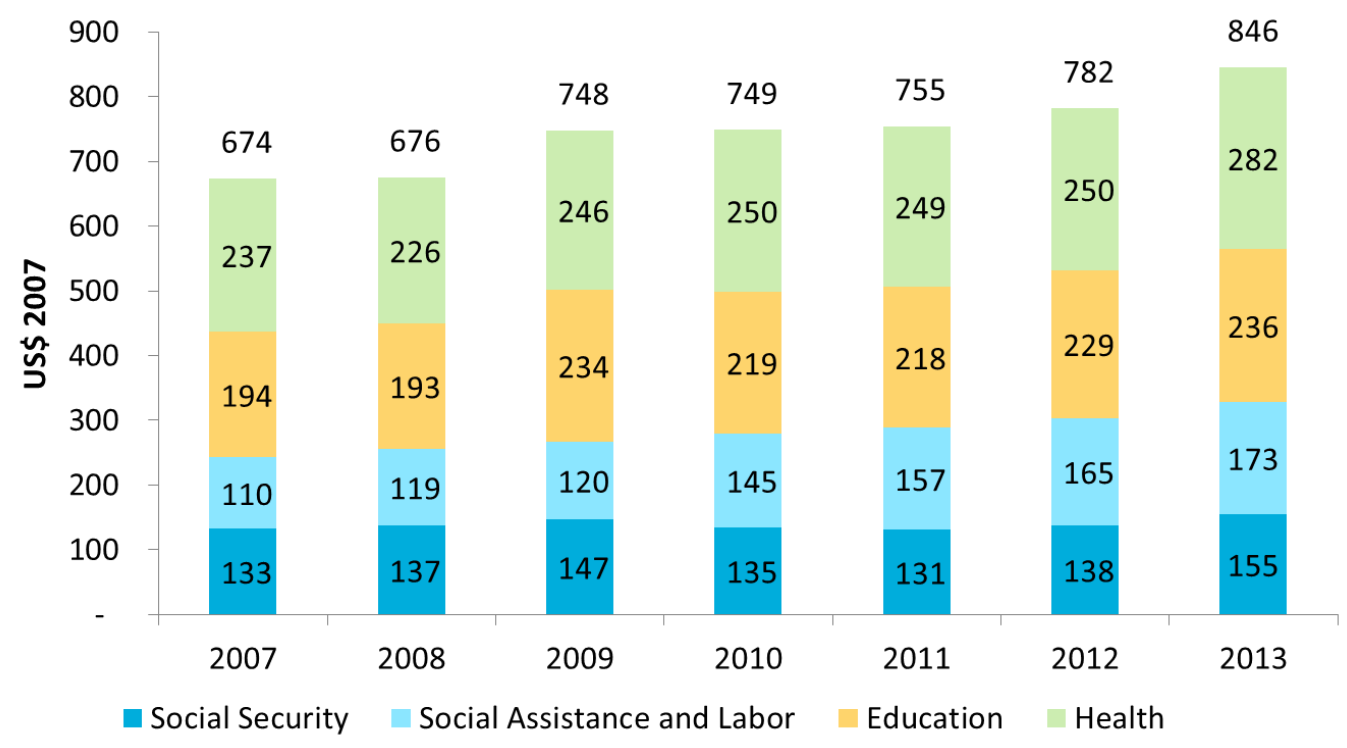

Source: World Bank's calculations from ICEFI social spending database

Despite the significant progress made in terms of social spending, E1 Salvador is still among the countries in the CA region with lower public spending on the social sectors. Despite the recent increase in social spending, El Salvador still falls behind Costa Rica, Honduras and Panama, only higher than Nicaragua and Guatemala (Figure 6). Looking at spending levels by sector, El Salvador stands out for its relatively low spending on education and social security.

Figure 6: Social sector spending in E1 Salvador and other Central American countries, 2013

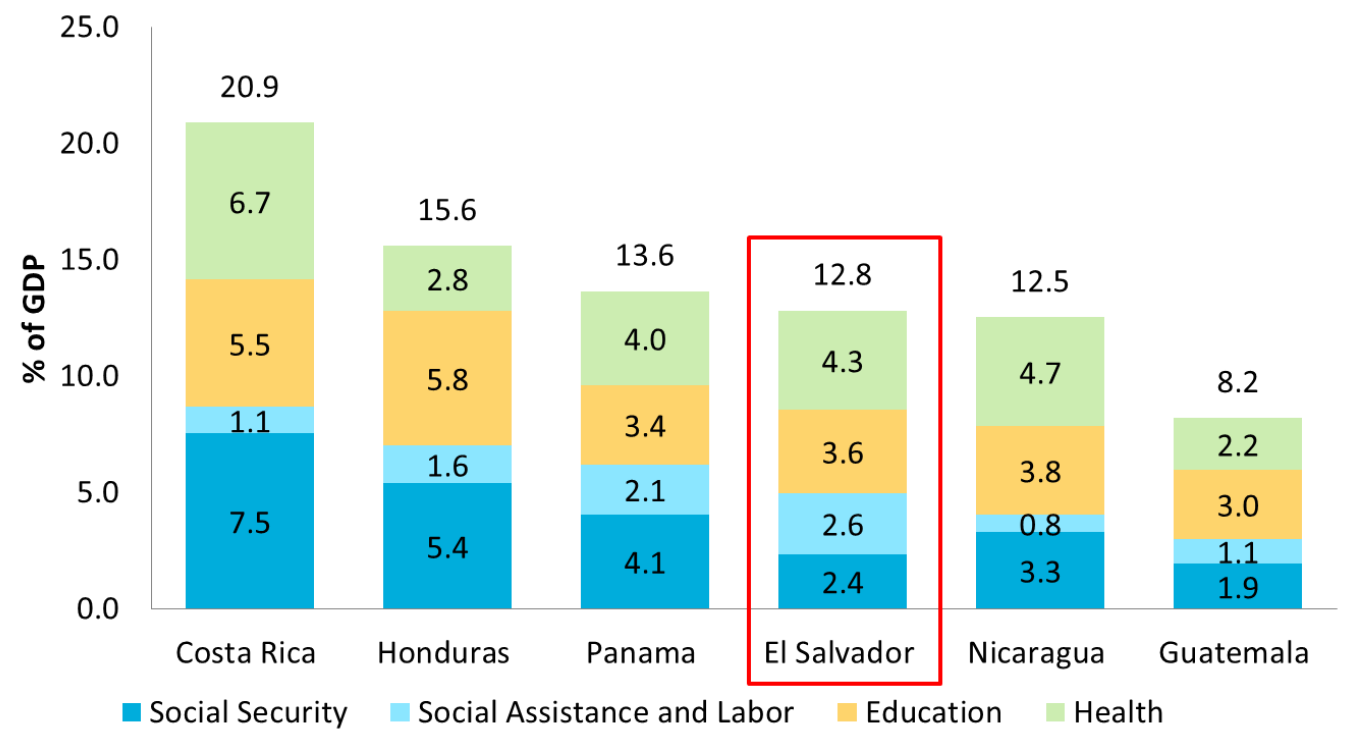

Source: World Bank's calculations from ICEFI social spending database 
Further expansion of social spending may not be fiscally sustainable, nevertheless, given the current level of revenues. During the last decade, both revenues and expenditures as percentage of GDP increased in El Salvador (Figure 7). However, expenditures have grown much faster than revenues, deteriorating the government's overall balance. Between 2007 and 2013, tax revenues increased 2 percentage points of the GDP, from 16.7 percent to 18.5 percent of GDP, while expenditures increased 4 percentage points of the GDP, from 18 percent to 22.1 percent of GDP. The fiscal deficit has persisted, despite some minor improvements in the last three years (20102013). In spite of measures that broadened the tax base and improved tax administration and enforcement since the 2000s (World Bank, 2004), a regressive value-added tax (VAT) system still shows a high incidence (Figure 8), and revenues are limited due to high levels of tax evasion.

Figure 7: General government overall balance, 2007-2013

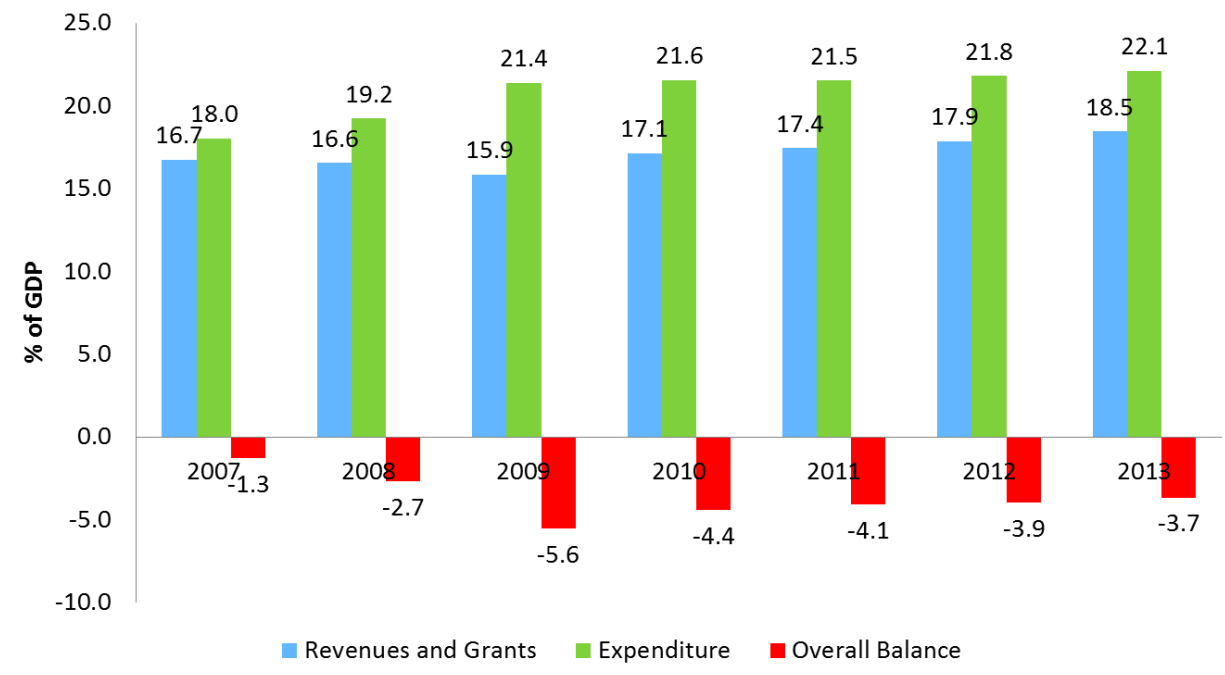

Source: IMF, World Economic Outlook Database, October 2014

Figure 8: Revenues of the non-financial public sector, by source (2008-2012, percent of GDP)

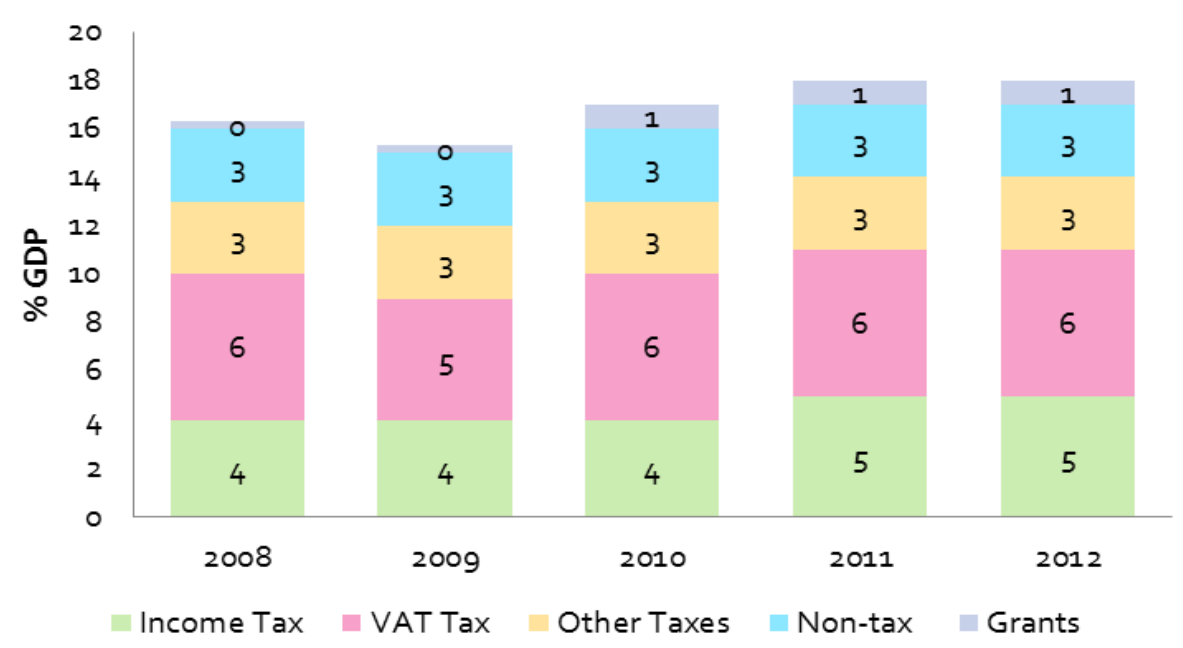


Source: World Bank’s calculations from ICEFI social spending database.

Not only is the sustainability of increasing social spending a challenge for E1 Salvador, so is the persisting low budget execution across social sectors. Between 2007 and 2013, the percentage of social spending budget that could not be executed within the fiscal year was around 5 to 8 percent of the budget (Figure 9). Both the education and health sectors were the social sectors with the highest levels of budget execution, reaching at least 93 percent five out of these six years. Social protection has been lagging behind, dropping below 93 percent two times throughout the same period. More recently, in 2012 and 2013, education and health reached 95 to 98 percent, while social protection stayed around 94 percent.

Figure 9: Budget execution of social spending, 2007-2013

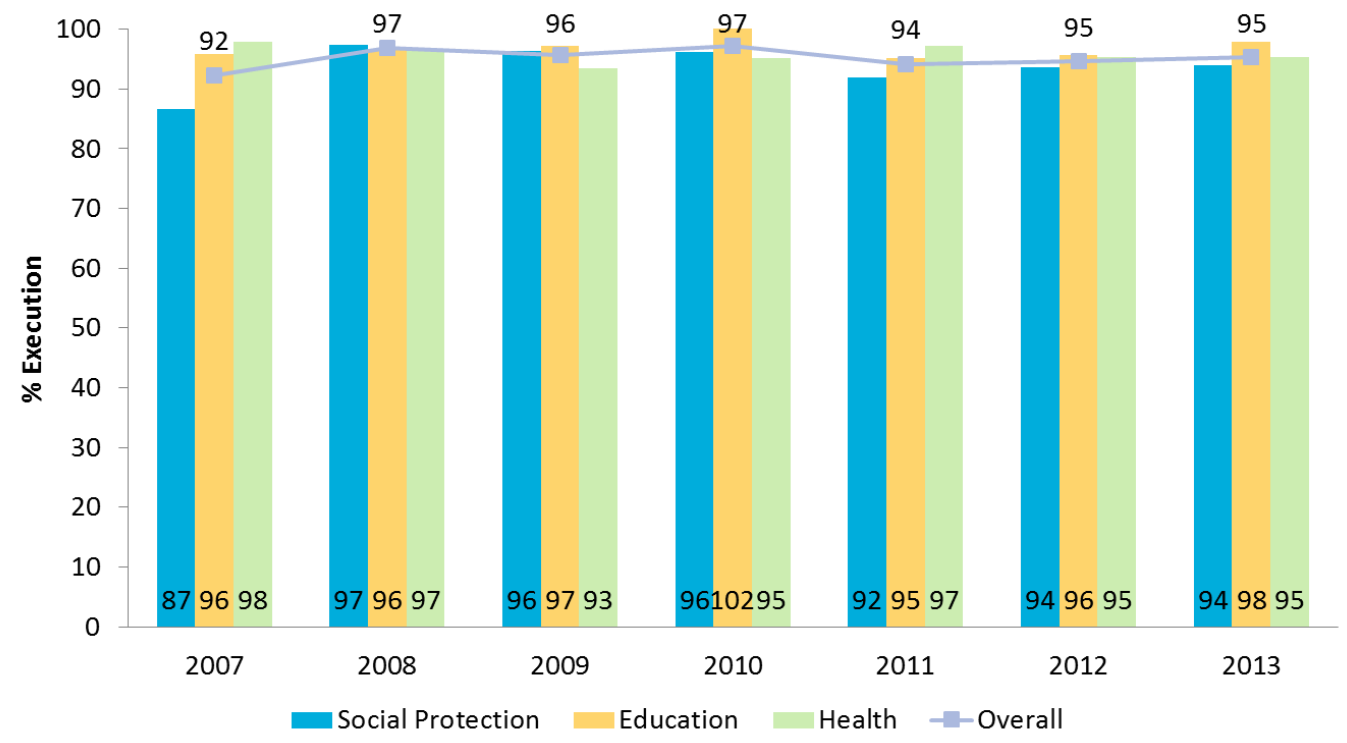

Note: Execution $=$ Executed $/$ Modified Budget

Source: World Bank's calculations from ICEFI social spending database

Improvements in planning and monitoring of social spending are also needed to improve El Salvador's budget management. The Technical Secretariat of the Presidency (STP) has traditionally led the macro strategic planning process. The STP developed the Five-Year Development Plan 2010-2014, which includes broad spending guidelines, defined strategic objectives, as well as revenues, spending and debt policies. However, there is no legal framework regulating this planning process. In addition, the process remains heavily centralized: the Legislative Assembly and the civil society are not consulted to draft this document. Recent progress in improving the access to fiscal information to the civil society was evident, though. This has happened through the use of technology, including the development of websites like the Fiscal Transparency Portal (Portal de Transparencia Fiscal) and the Active Transparency Portal (Portal de Transparencia Activa). These information systems and their statistics are considered reliable, but they 
have room for improvement. In addition, the STP has undertaken a major effort to measure and track spending in social sectors, a significant challenge insofar as budget is not reported at program level but at institutional level. The series of social public spending for 2004-2012 has already been published on the web. Still, measurement of public spending effectiveness and efficiency remains a challenge, as is the monitoring of results from social spending.

Given fiscal constraints, El Salvador needs to take further steps to improve both the efficiency and the effectiveness of its public social spending. In spite of the public sector modernization, which has been under implementation since 1994, an analysis of spending efficiency and effectiveness of the social sector shows that El Salvador has significant room for improvement on both fronts, as evidenced by the relationship between social outcomes and public spending.

Figure 10 shows a comparison between the levels of Public Sector Performance (PSP) and Public Sector Efficiency (PSE) in El Salvador and in other LAC countries ${ }^{2}$. The PSP is a composite indicator based on socioeconomic variables ${ }^{3}$ that are assumed to be the output of public policies ${ }^{4}$. This indicator summarizes the effectiveness of public spending in improving social outcomes. The PSE indicator then relates PSP scores to the total public spending in these sectors ${ }^{5}$. It represents the "public value" per public dollar spent. The overall social public spending in El Salvador is considered less effective and less efficient than most of the other LAC countries. This means that, on average, other LAC countries get a higher return (improvement in social indicators) per dollar of social public spending. Interestingly, there are differences across sectors. Whereas the education sector tends to be as a less effective, but efficient sector - probably due to the low public spending level - both the health and social protection sectors are classified as less efficient, but effective sectors. In other words, when compared to other LAC countries, El Salvador's education sector appears to achieve good outcomes per dollar spent; on the contrary, El Salvador's health and SPL

\footnotetext{
${ }^{2}$ We follow the methodology by Afonso, Schuknecht, and Tanzi $(2005,2010)$ for OECD countries and that of Afonso, Romero, and Monsalve (2013) for LAC.

${ }^{3}$ For education, we take gross secondary enrollment and literacy rate; for health, infant mortality rate and immunization measles; and for social protection and labor, inequality (measured by the Gini coefficient) and extreme poverty headcount (percentage of population earning less than $\$ 1.25$ a day)

4 To obtain PSP indicators we assign equal weights to each sub-indicator, computed as the average of the corresponding outcome indicators, each one of them normalized by its sample mean. The PSP indicator for each country is then obtained by averaging the values of all sub-indicators. Resulting PSP scores are then related to the average value of one of the normalized output indicators. Hence, countries with PSP scores in excess of one are seen as good performers, as opposed to countries with PSP values below the mean.

5 PSE weights public sector performance in each area by the amount of relevant public expenditure that is used to achieve such performance. To compute PSE scores, public spending is normalized across countries, taking the average value of one for each of the aforementioned expenditure categories.
} 
sectors do achieve better outcomes, on average, than the remaining LAC countries, but a much higher cost (less efficiently) than they do.

Figure 10: Public Sector Performance and Efficiency in E1 Salvador and LAC, 2010.

Overall social public spending

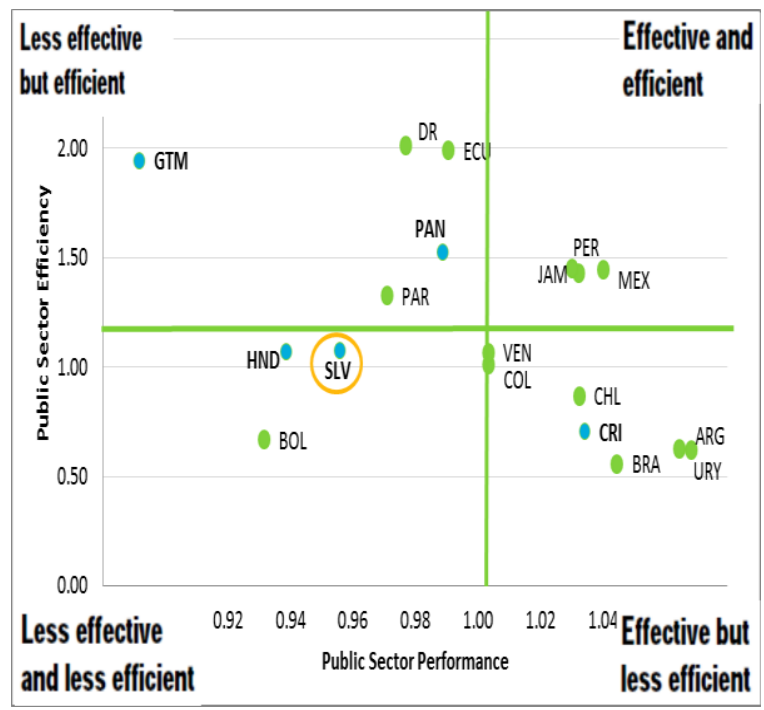

Health public spending

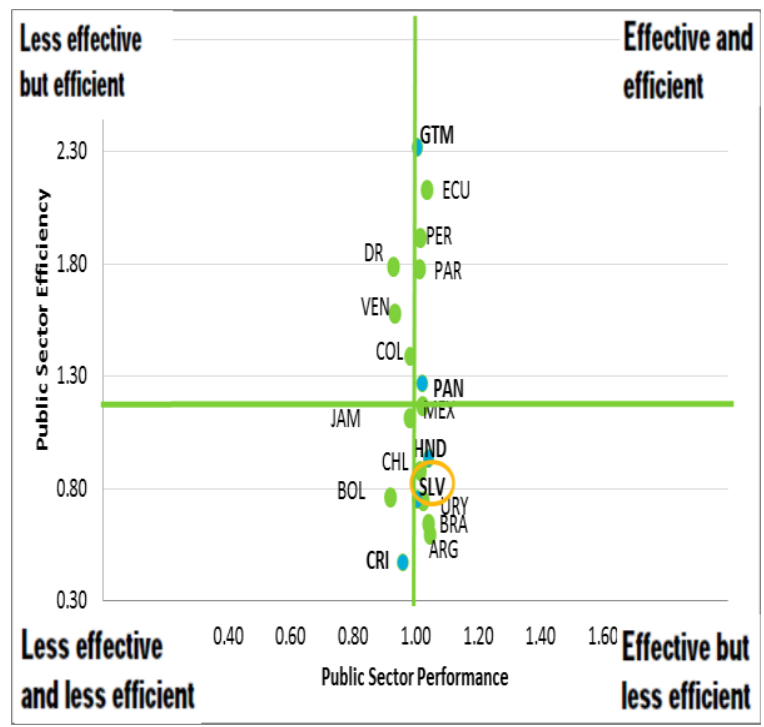

Education public spending

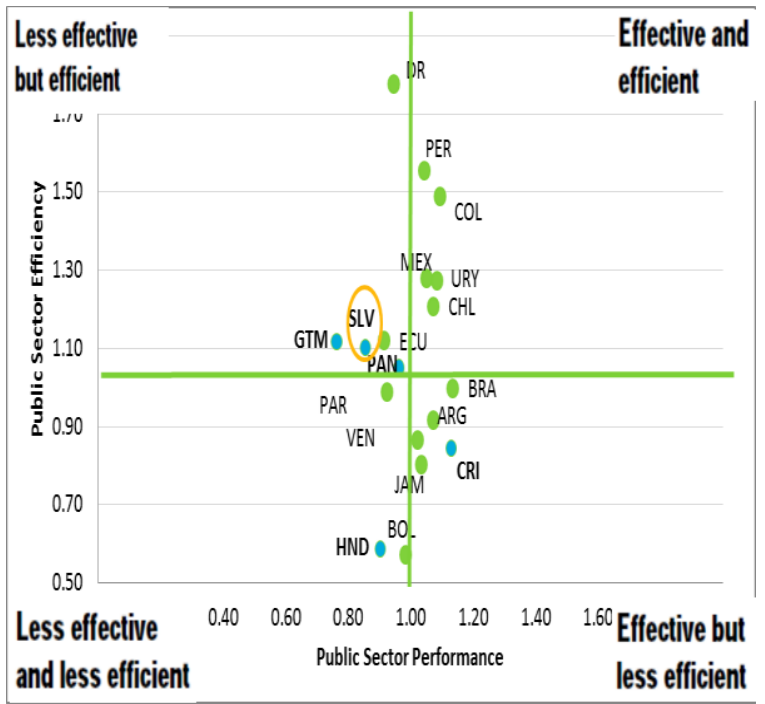

Social protection \& labor public spending

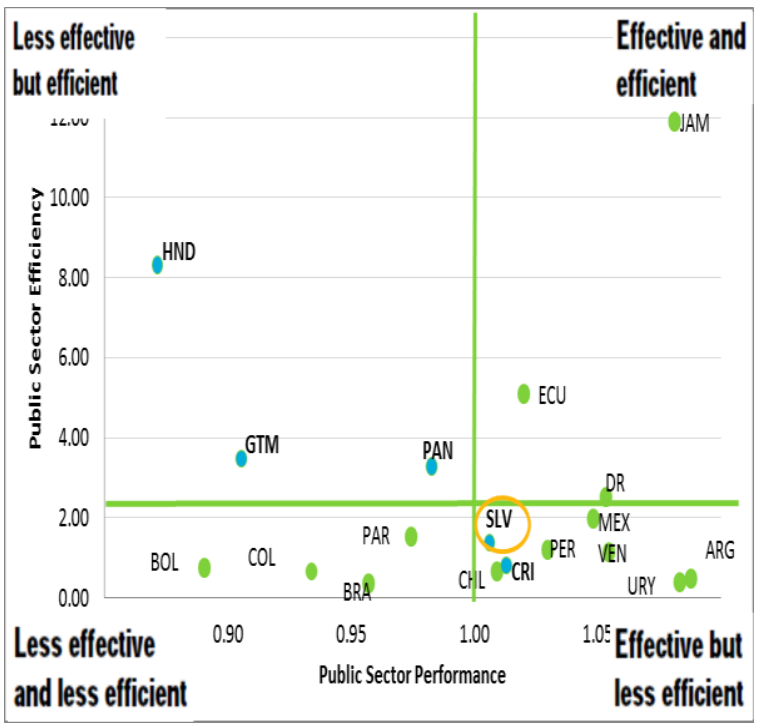


Source: World Bank's calculations using CEPAL and WDI databases

A LAC "production possibility frontier" analysis shows that E1 Salvador could increase its social performance by as much as 15 percent with the same level of public social spending. Figure 11 shows the production possibility frontier for total social public spending for LAC, applying the data envelope analysis (DEA ${ }^{6}$ ) using the PSP scores as an output and social-public spending-to-GDP ratios as an input. According with the DEA analysis, El Salvador is far away from the LAC "production possibility frontier". This means that El Salvador could increase its social performance by 9 percent, with the current level of public social spending.

Figure 11: Production Possibility Frontier (Data Envelope Analysis) for Social Public Spending, E1 Salvador and LAC, 2010.

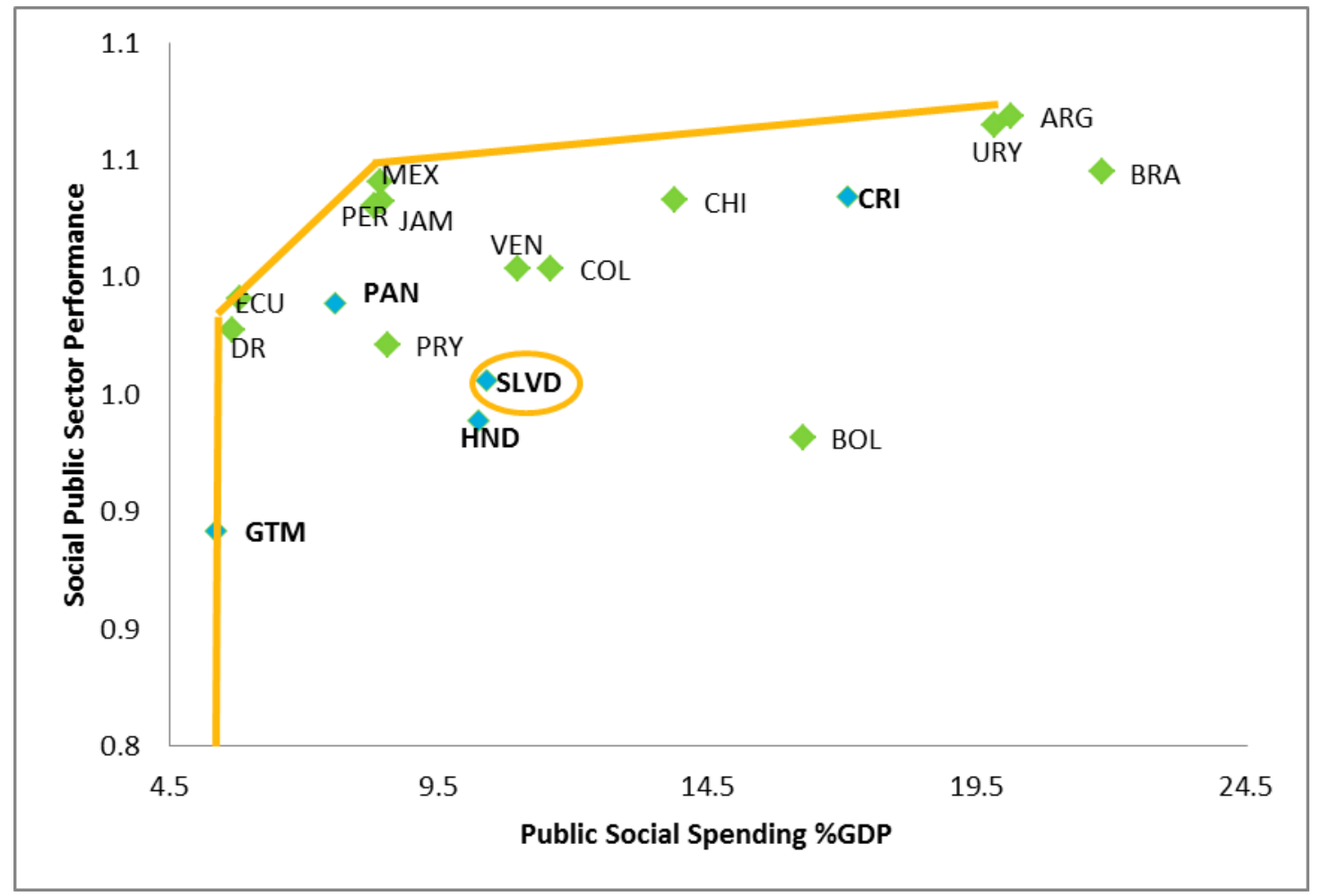

Source: World Bank's calculations using CEPAL and WDI databases.

\footnotetext{
6 The DEA methodology developed by Farrell (1957) assumes the existence of a convex production frontier which envelops the set of observations. Countries located in the production frontier are considered efficient while countries inside the frontier exhibit inefficiency (for the observed social public spending level, the actual output is smaller than the best attainable one). See Coelli et al. (1998) and Thanassoulis (2001).
} 


\section{Performance and Challenges in Education}

\section{III.1 Recent Evolution of Public Spending on Education}

Public spending on education has increased in El Salvador, but remains low according to international standards. Public spending on education represented 3.6 percent of its GDP in 2013, as compared with 2.8 percent in 2007. Nevertheless, public expenditure on education is still low both when compared to OECD standards, neighboring countries in CA, and "comparator countries" (Figure 12). Education spending makes up for 29 percent of social spending in El Salvador and it has been constant over time in the last few years (Figure 13). Basic education takes up the bulk of public spending on education (69 percent in 2013), as compared with 9 percent devoted to upper secondary education and 10 percent allocated to tertiary education. Countries with a higher level of economic development tend to show more balanced spending across levels, with their spending on primary education ranging between 20 percent and 35 percent.

Figure 12: Public spending on education versus GDP per capita (circa 2012)

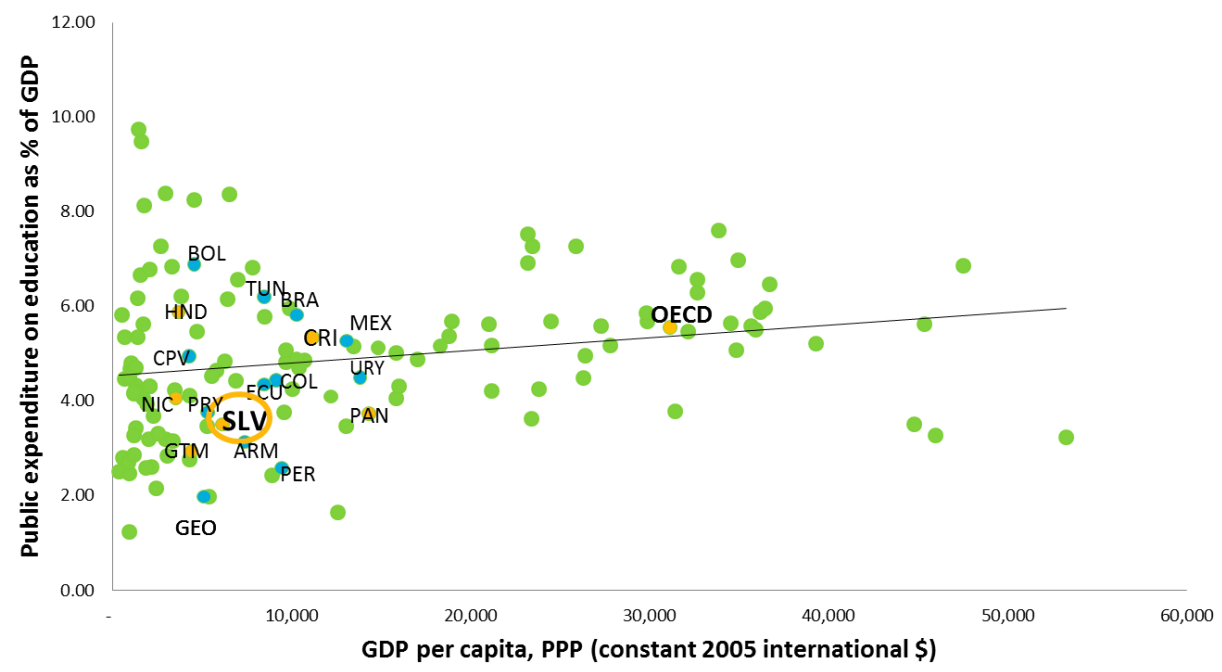

Source: World Bank's calculations based on ICEFI social spending database for CA; EdStats for the rest of the countries.

Figure 13: Public spending on education as $\%$ of social spending ( $\%)$ 


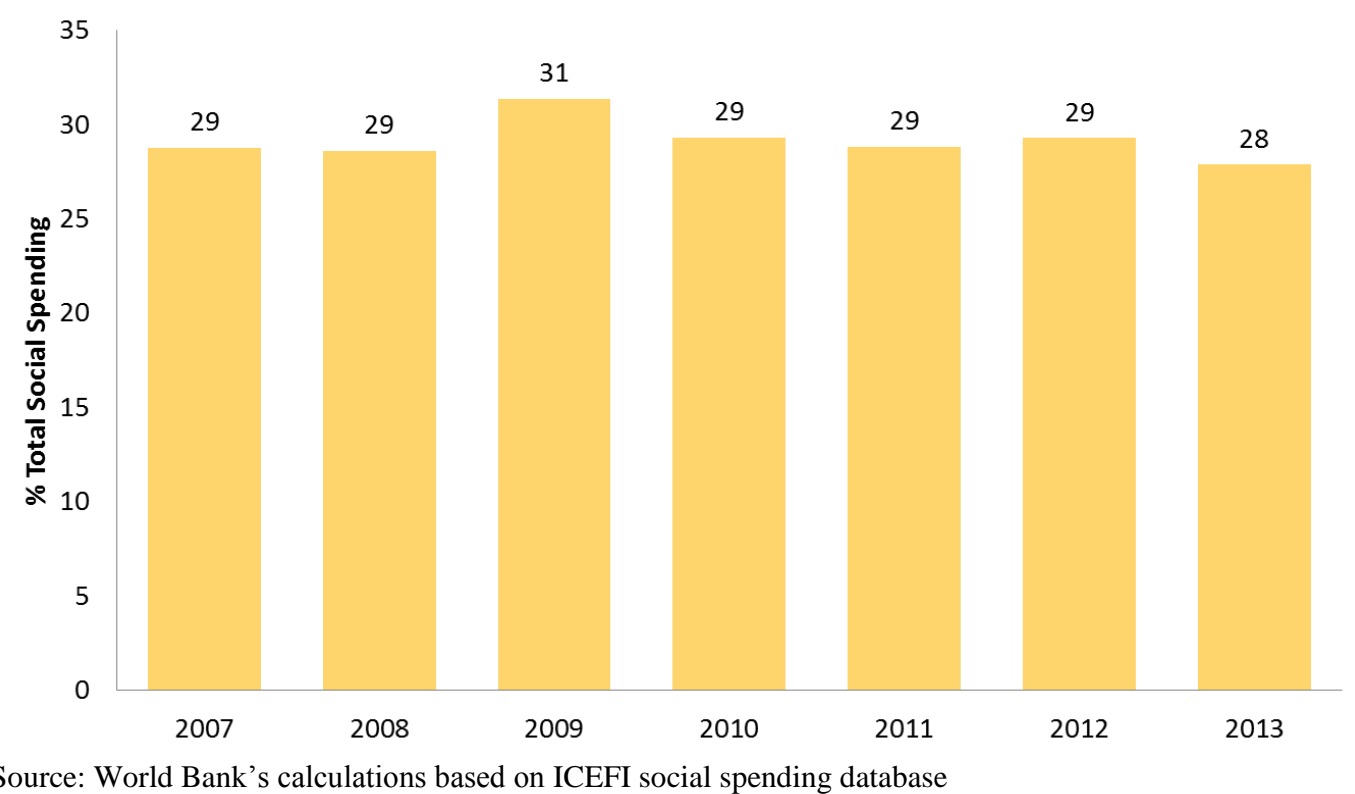

Average per student spending has also increased in the last few years, although with differences across levels. In fact, per student expenditure on pre-primary and basic education has increased annually faster than on upper secondary education (Figure 14 and Figure 15). Between 2007 and 2012, per student spending in pre-primary and primary education increased 7 percent annually, whereas the increase in per student spending on upper secondary level slightly increased 0.2 percent annually. As a result, for example, the average public expenditure for each student in upper-secondary education in 2012 is US\$811, as opposed to US\$802 in 2007. While the increase in per student public expenditures on basic education can be partly explained by the reduction (2\% annually, on average) of students enrolled in the period between 2007 and 2012, the increase in spending per student in upper-secondary education was accompanied by an average annual increase in enrollment of 3 percent over the same time period. There was no variation in the number of students enrolled in pre-primary during the same time period. 
Figure 14: Per student public spending on pre-primary and basic education (PPP, US\$2007)

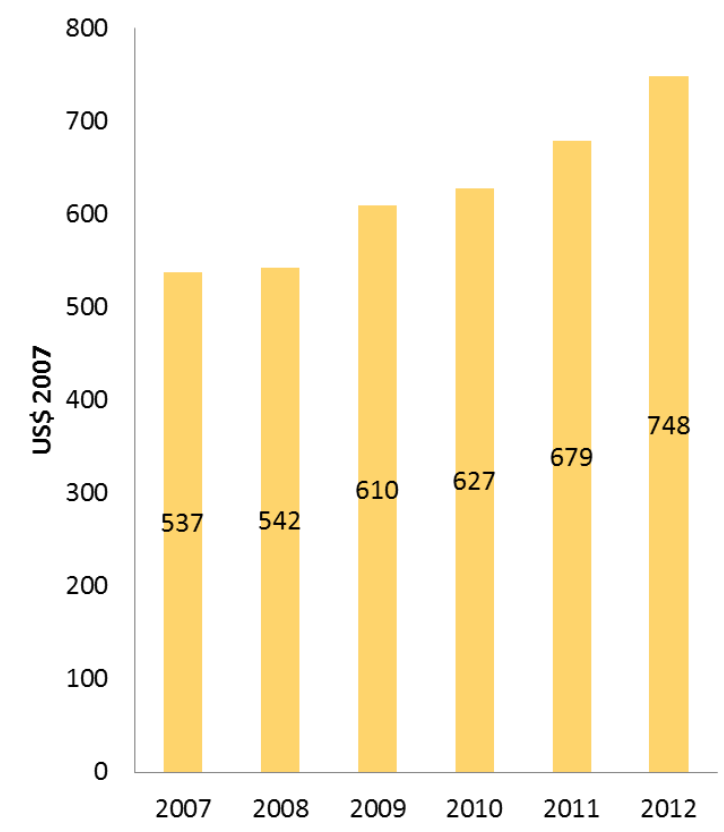

Source: World Bank's calculations based on ICEFI social spending database
Figure 15: Per student public spending on upper secondary education (PPP, US\$ 2007)

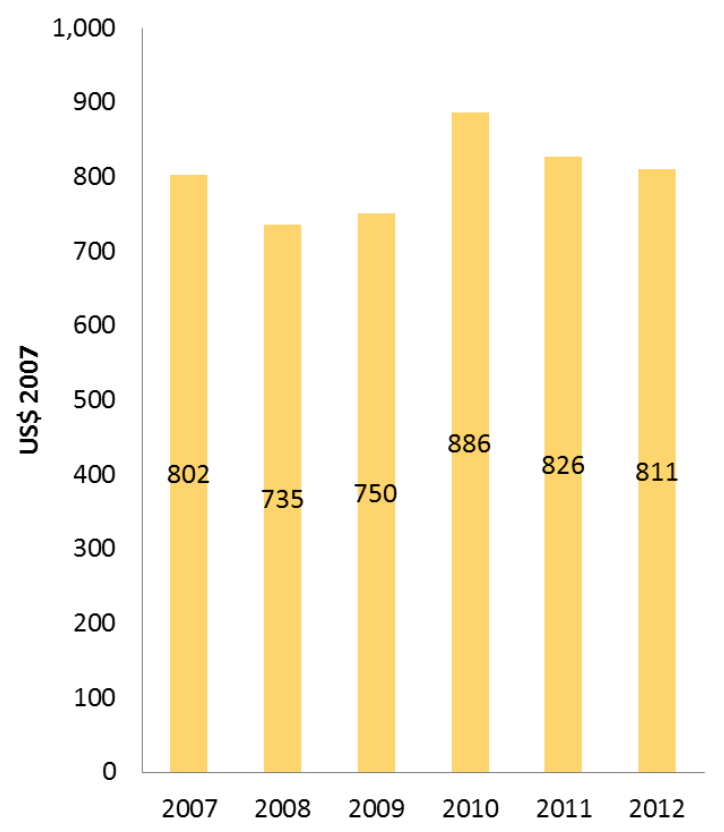

Source: World Bank's calculations based on ICEFI social spending database

The share of salaries to total public spending on education (wage bill) in El Salvador increased in the last few years; still, at 63 percent, the wage bill is lower than most countries in the CA region. For instance, the wage bill in Honduras accounts for about 90 percent of the total public education expenditure and the share in Nicaragua is 79 percent. Lower spending in wage bills is usually associated with higher expenditure in capital investment, which is considered a better predictor of education quality. For instance, in Finland and Korea-commonly considered among the top education performers - the wage bill accounts for 50 percent of the total public education expenditure (Figure 16). Therefore, El Salvador with a relatively low wage bill (73 percent of the total education spending) and low learning outcomes represents an exception to this stylized fact. The wage bill in El Salvador's education sector has been increasing over time, with an average increase of 2 percent per year over the period between 2007 and 2013 (Figure 17). This was driven by both an increase in the number of teachers and in teacher salaries. The number of teachers rose from 58,734 in 2007 to 60,221 in 2011 . This increase led to a reduction of the student-teacher ratio from 30.3 in 2007 to 28.7 in 2011 (Figure 18). Nevertheless, the student-teacher ratio remains among the highest in the region and much higher than those in comparator countries with similar level of GDP, such as Armenia and Georgia (Figure 19). Evidence from the household surveys also suggests that average teacher salaries have increased significantly, compared to average salaries earned by tertiary education graduates employed in other occupations. While in 2007, monthly salaries for teachers were 17 percent lower on average than those of other tertiary education graduates; in 2011 they were in line with those of tertiary education graduates employed in other occupations. 
Figure 16: Wage bill as a $\%$ of public education spending by countries (\%)

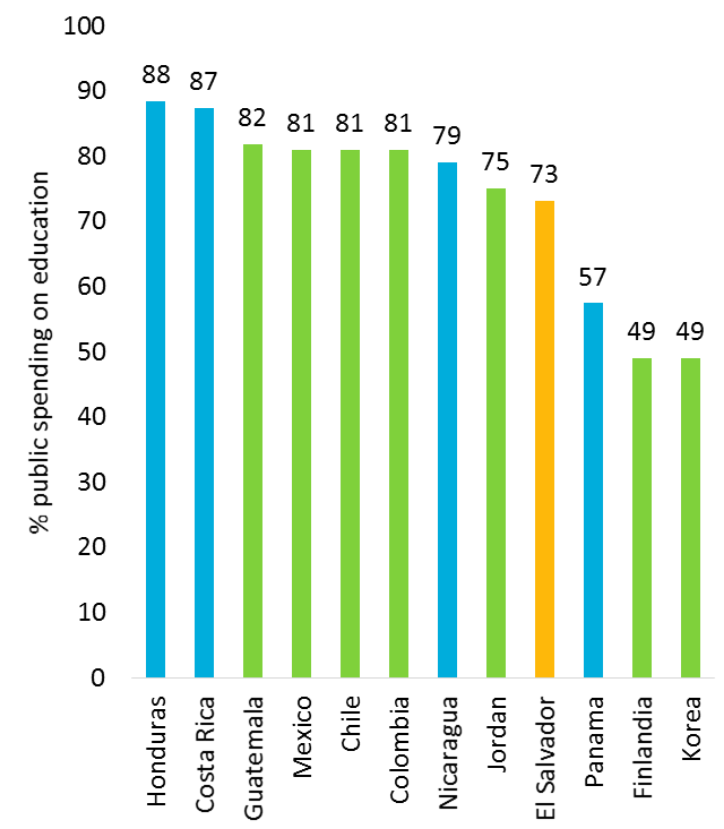

Source: World Bank estimation based on official data for El Salvador (2011). EdStats for the rest of the countries.
Figure 17: Wage bill as a $\%$ of public education spending 2007 and 2013 (\%)

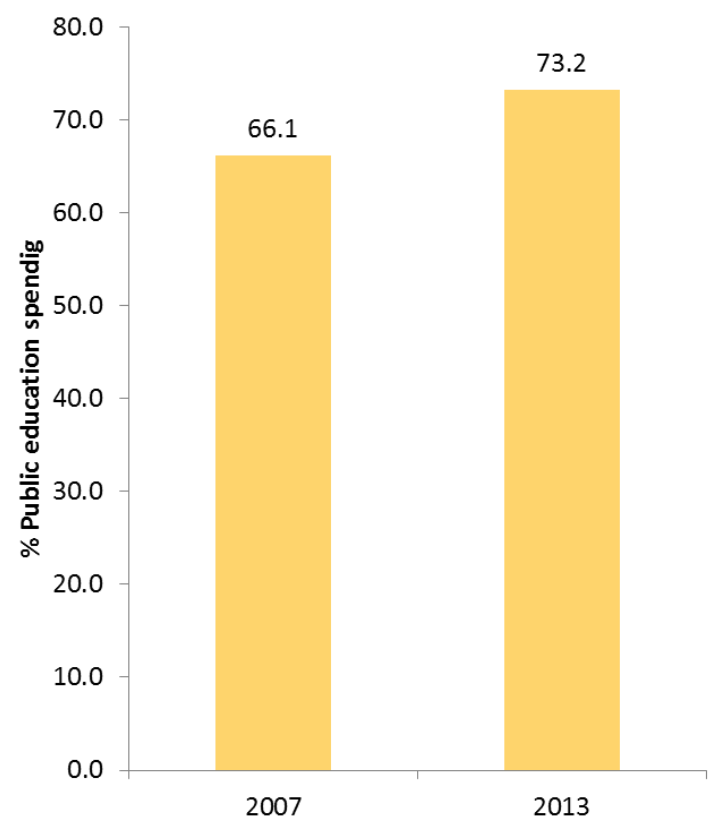

Source: World Bank SSEIR / ICEFI social spending database, MINED Salvador 
Figure 18: Student/teacher ratio and number of teachers

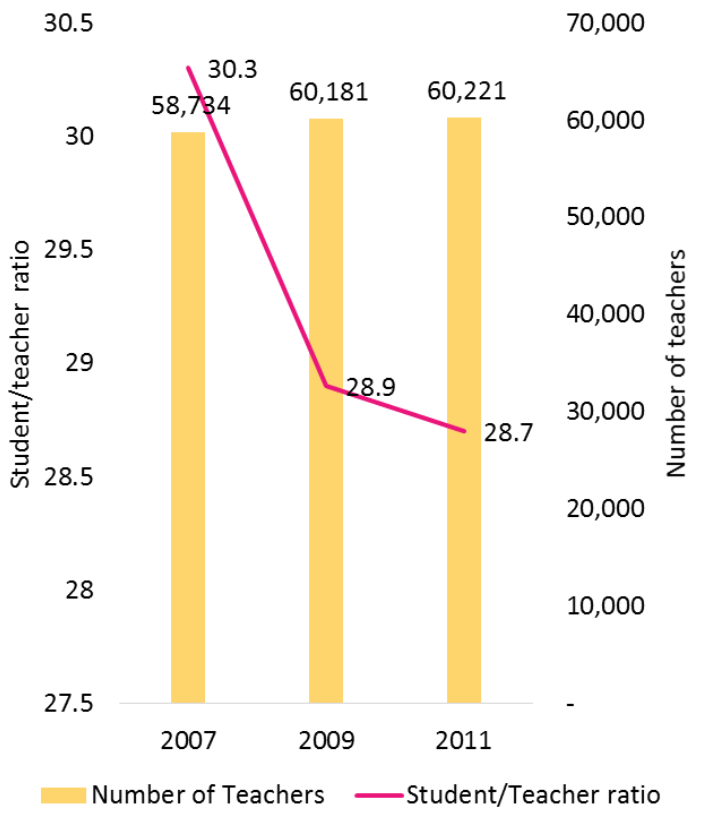

Source: Own calculations based on MINED spending data and School Census data on the number of teachers.

\section{Figure 19: Student/teachers ratio per level of GDP}

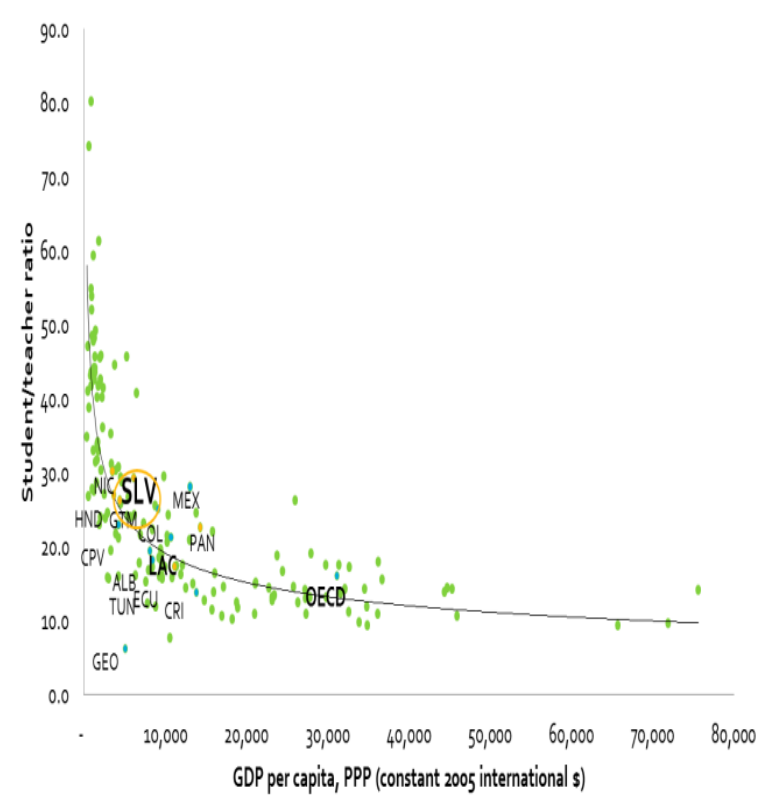

Source: EdStats

Teachers in El Salvador work fewer hours and earn more than other similarly educated professionals, and remunerations have no linkage with performance. On average, monthly salaries for teachers with a completed tertiary-level education are not different from those employed in other occupations, but hourly wages are 12 percent (in 2011) higher overall due to fewer working hours of teachers compared to other professionals. Results in Bruns et al. (2013) find that teachers in El Salvador, together with those in Mexico, earn more per hour than teachers elsewhere in the LAC region. Moreover, the fact that salaries are not linked at all to performance reduces the scope that monetary incentives can have in boosting learning outcomes.

\section{III.2 Results and Outcomes}

Even though enrollments for all school levels rose, the gross enrollment ratio in uppersecondary education is still dramatically low. Between 2000 and 2012, the gross enrollment ratios rose across all the education levels. For instance, ratios rose from 104 percent in 2000 to 113 percent in 2012 at the primary level. In addition, more students are now completing primary education. While in 2005, only 85 percent of the children enrolled completed in 2011 this number rose to 101 percent. Enrollment in upper secondary also rose. However, in 2012 gross enrollment 
level at the upper secondary was still 48 percent, well below other countries in the region, such as Nicaragua and Guatemala (Figure 20). Moreover, comparator countries with similar levels of GDP, such as Jordan and Albania, display much higher ratios.

Figure 20: Gross enrollment ratio, upper secondary education vs. GDP per capita (circa 2011)

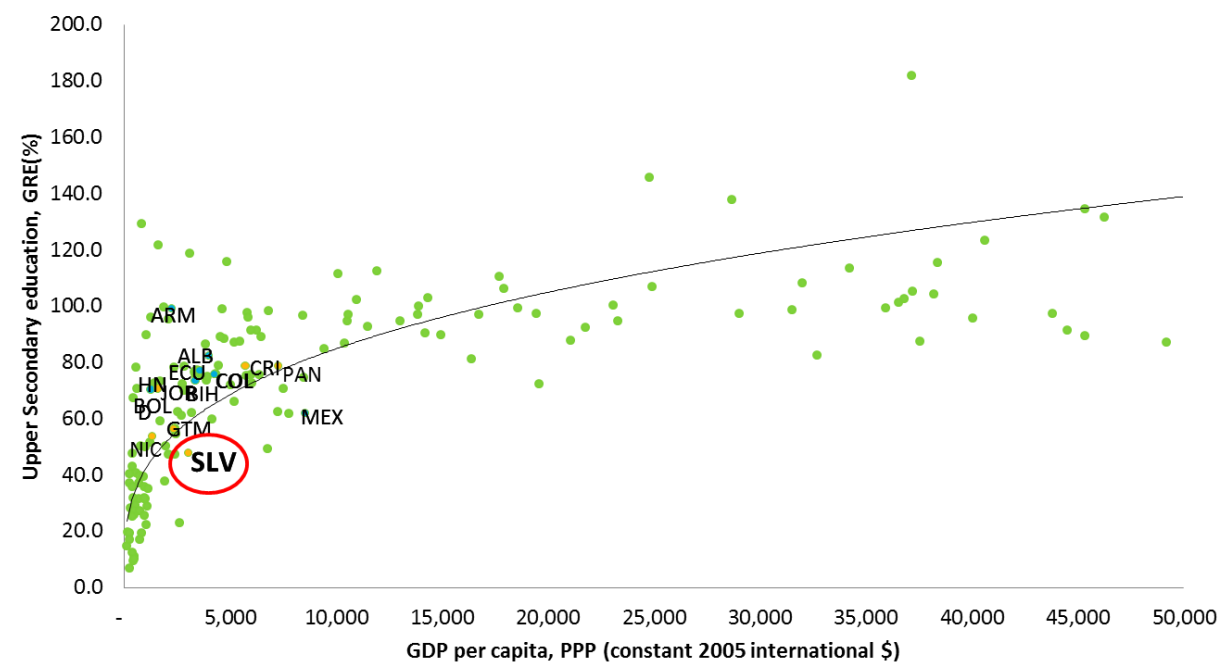

Source: EdStats. Upper secondary education corresponds to the last three grades of school.

Furthermore, there are large inequalities within the country in access to secondary education. The differences in education. The differences in enrollment between urban and rural areas increase dramatically with age, once children have age, once children have completed the lower cycle of basic education. Children start to drop out of school at about age 12 school at about age 12 in rural areas, and age 14-15 in urban areas (Figure 21 and Figure 22). However, there are no disparities by gender (Figure 23 and

Figure 24). Among children age 18, the probability of being in school for those in urban areas is 50 percent, as opposed to 30 percent for those living in rural areas. The large differences in enrollment associated to the socio-economic status and geographic area can be explained mostly by financial constraints and lack of interest - with the latter likely due to the lack of available information about returns on education. According to the information collected in the 2013 household survey, 70 percent of the children in rural areas, and in the secondary age rage, who are not attending school report the following three as the main reasons: 1) lack of interest, 2) the need to work and 3) the inability to afford education. 
Figure 21: Attendance rates by location and by age, 2013

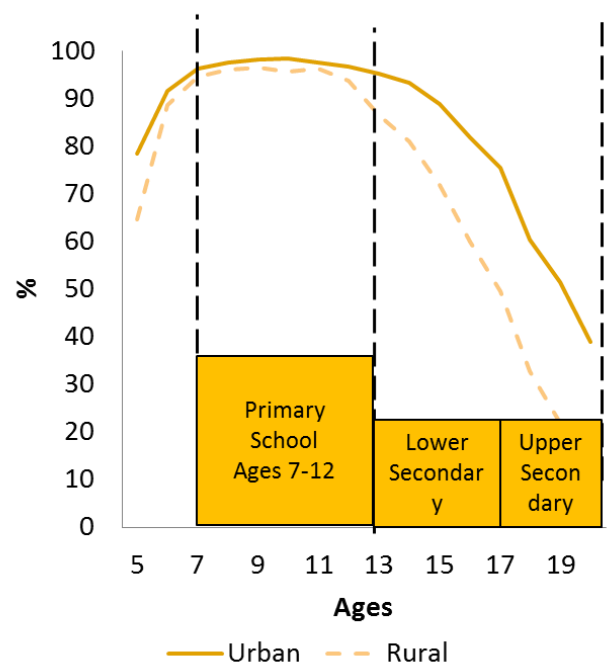

Source: World Bank SSEIR team's analysis of household surveys, authors' calculations using standardized ADePT software (Education Module)

Figure 22: Proportion of 15-19 years old that completed each grade by area, 2013

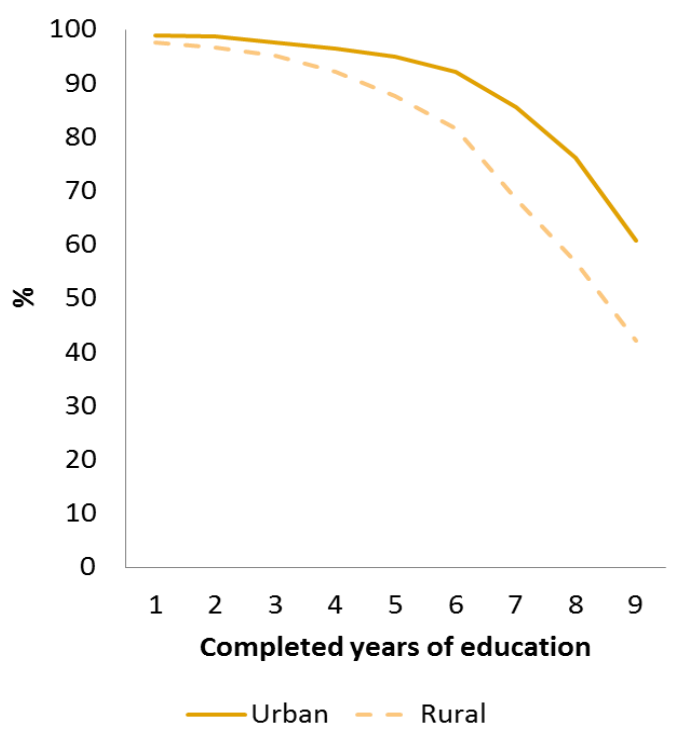

Source: World Bank SSEIR team's analysis of household surveys, authors' calculations using standardized ADePT software (Education Module)
Figure 23: Attendance rates by gender and by age, 2013

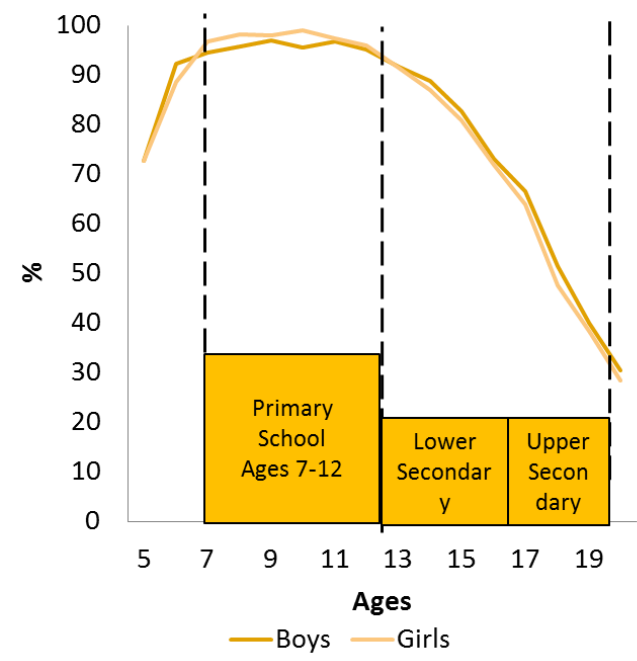

Source: World Bank SSEIR team's analysis of household surveys, authors' calculations using standardized ADePT software (Education Module)

Figure 24: Proportion of 15-19 years olds that completed each grade by gender, 2013

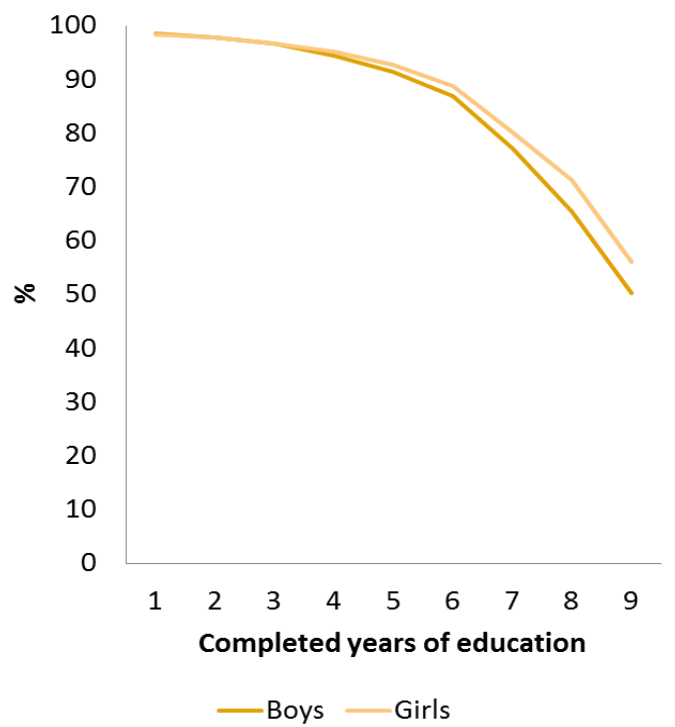

Source: World Bank SSEIR team's analysis of household surveys, authors' calculations using standardized ADePT software (Education Module)

Learning achievements lag behind comparator countries and are lower for public school students than private. In 2007, the average score of the Salvadoran 4th graders who took the 
TIMSS test in Mathematics was below 350 points. In comparison, Armenia, whose level of GDP is comparable to El Salvador (Figure 25), achieved an average of 500 for the students who took part in the same test. Not only are the levels of learning low, but when comparing the results for the gross enrollment rates there are large differences within El Salvador. According to results from the 2012 PAES, a national standardized test for secondary school students, 6th graders in top performing private schools do much better than 6th graders in top public schools. There are no significant differences for students who attend schools at the bottom of the quality distribution, irrespective of whether the school is public or private.

Figure 25: TIMSS 2007 Mathematics 4th grade versus GDP per capita

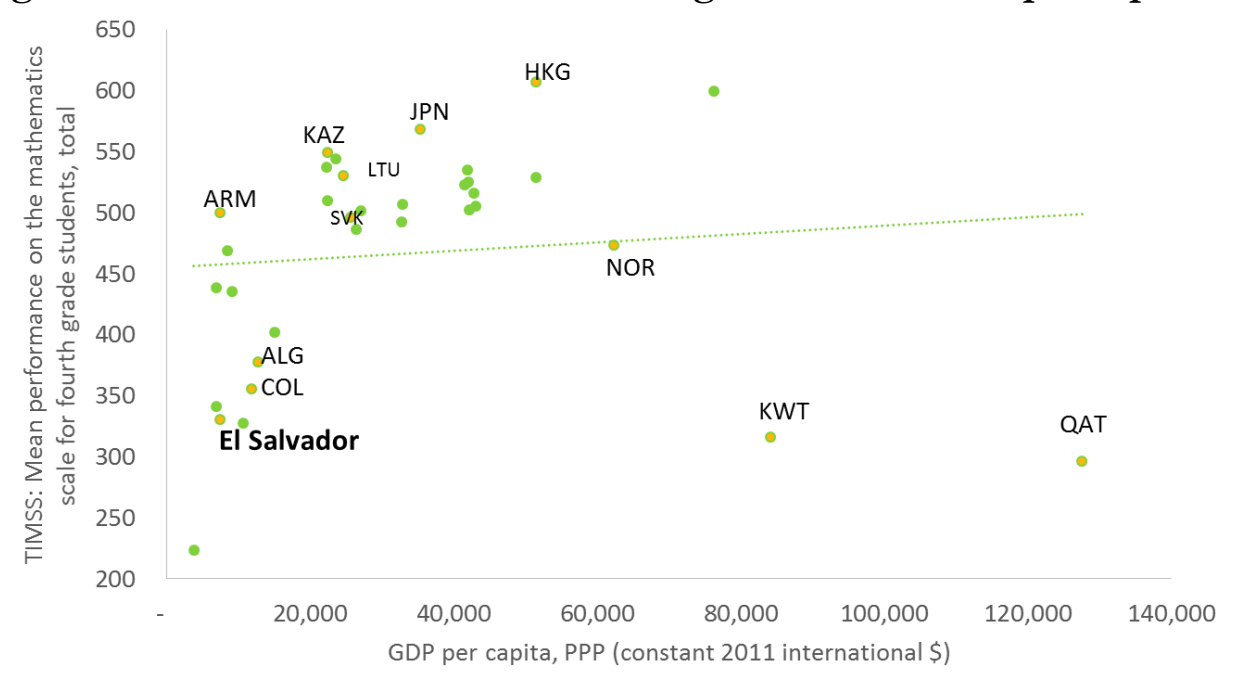

Source: TIMMS, 2007

Increases in per-student spending did not translate into improvements in learning outcomes. So far, we have seen that increases in public spending on education were with higher enrollment and better access to schooling, but not with improvements in spite of the improvements in the "quantity" of the educational inputs, as proxied by the teacher ratio, learning outcomes have not improved. Between 2007 and 2012, the public on education per student in primary education increased on average by 42 percent, from US\$779 (Figure 26). Nevertheless, a comparison of test score results in Language and Mathematics for 3rd graders, as measured by the country own national test score (PAESITA), shows no change over the period between 2005 and 2012 (Figure 27Figure 27: Test Results (average scores)

). Moreover, while the average expenditure per student in upper-secondary rose from US\$802 in 2007 to US\$811 in 2012, the average result in Math (as measured by the PAES) dropped from 5.3 to 4.2 (Figure 28Figure 28: Upper secondary learning outcomes vs per-student spending). This result might be partly explained by a "selection effect" of the entry cohort: as more students enter uppersecondary education it is likely that the average quality of the students drops, thus leading to a reduction in the level of learning. Therefore, an improvement in the "quality" of the educational 
inputs, primarily teachers, seems to be a necessary condition to improve learning outcomes (see Bruns, et. al., 2013). As we will discuss ahead, further reforms are needed to improve impacts and ensure the next generations are educated and productive.

Figure 26: Public spending in education per student in primary (US\$2007)

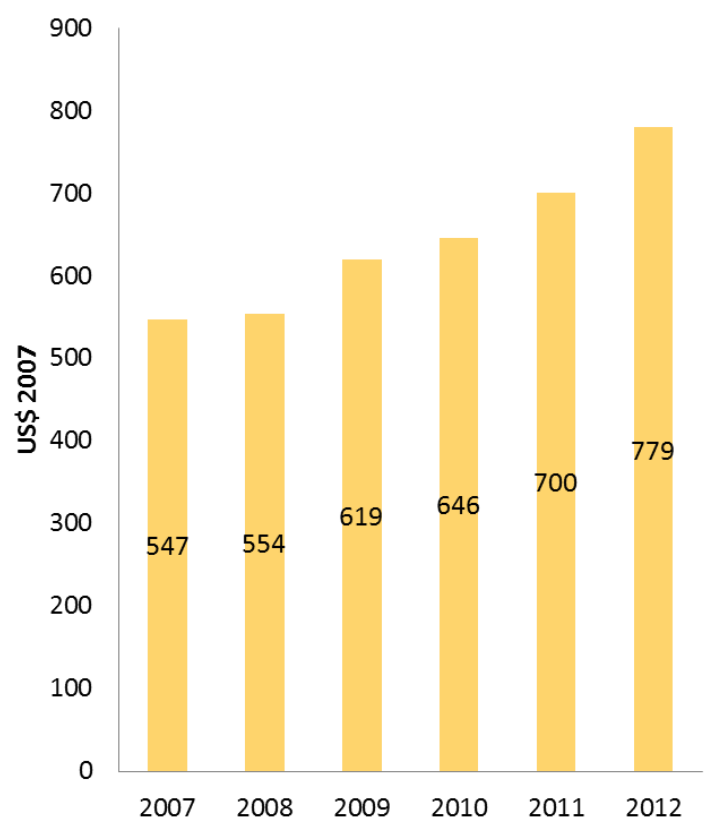

Source: World Bank SSEIR / ICEFI social spending database
Figure 27: Test Results (average scores)
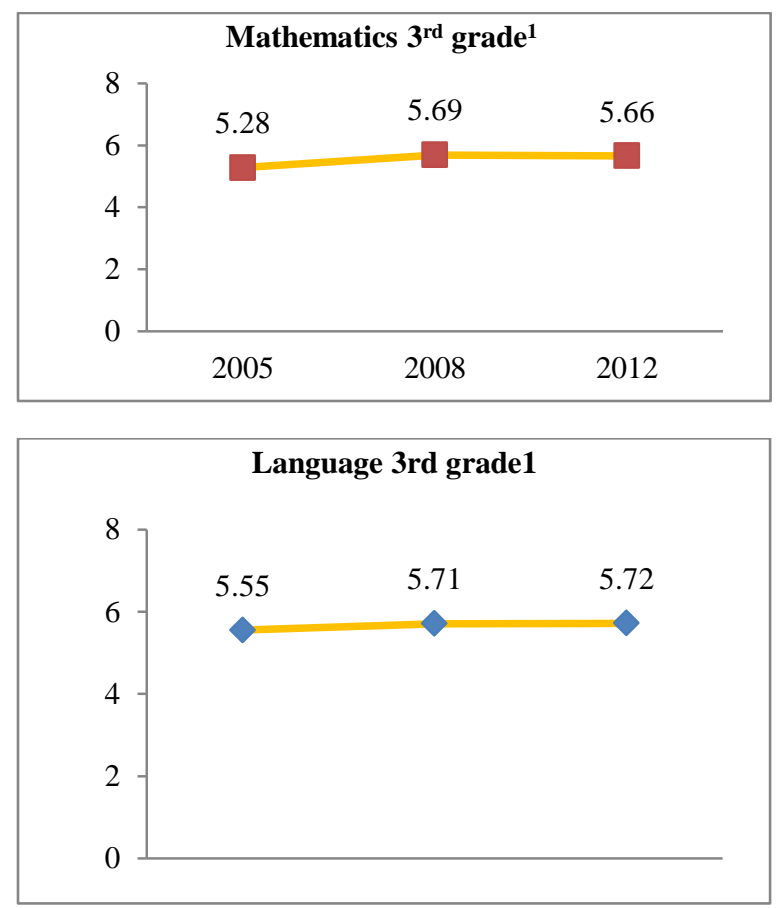

Source: PAESITA.

Figure 28: Upper secondary learning outcomes vs per-student spending

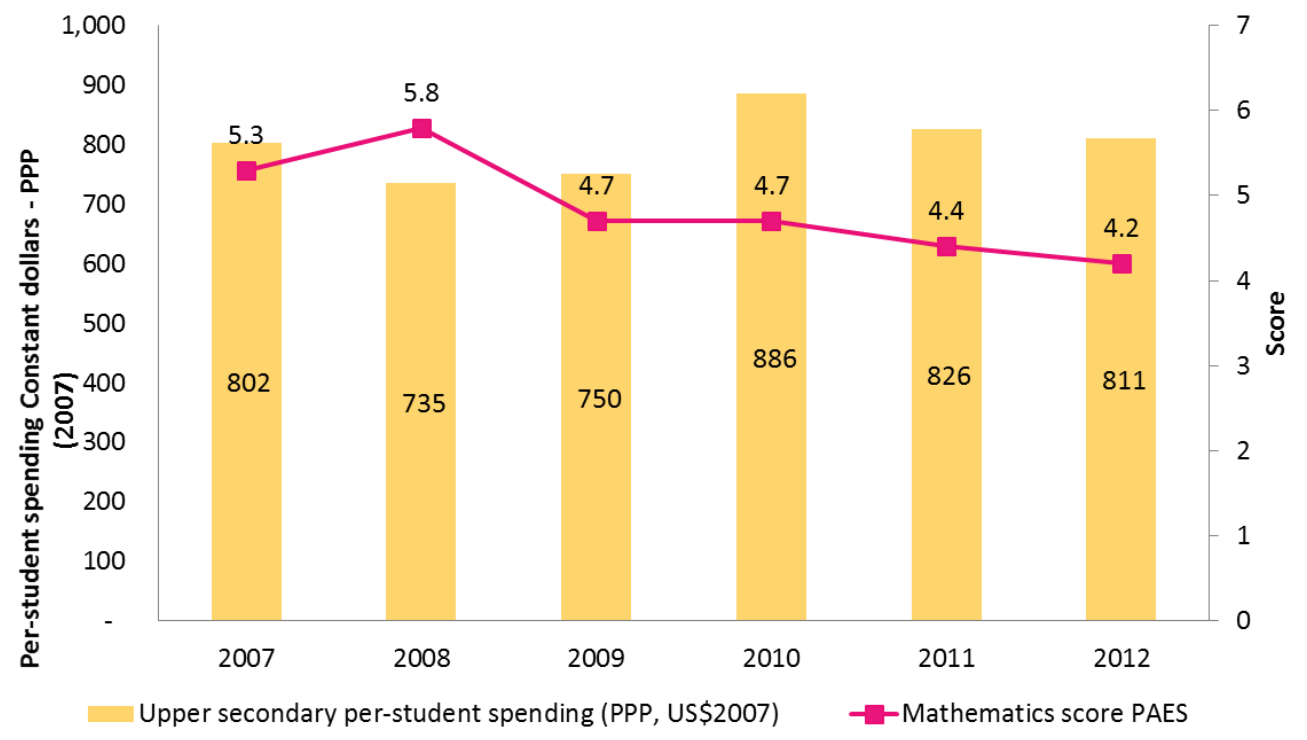


Source: World Bank SSEIR / ICEFI social spending database, EdStats, official data in Aspectos Institucionales del Sector de Educación de El Salvador

The lack of quality in the El Salvador public education induces families to flee the public system and attend the private schools of good quality, when they can afford it. While objective measures of quality of public education are not available, subjective measures like perceptions on quality, as elicited in the Latinobarómetro (2011), show that less than 30 percent of the Salvadorans perceived improvements in the quality of the public education system in the 10 years prior to the survey, as opposed almost 60 percent among the Costa Ricans. As a result, a large fraction of children belonging to the wealthiest families tend to send their children to private schools: according to the 2013 Household Survey, 54 percent of those belonging to the 5 th income quintile attended private schools (Figure 29Error! Reference source not found.). Only 4 percent of those in the first quintile of the income distribution attend a private school. The private schools attended by the wealthiest are those with better quality standards, thus suggesting that the gap in students' learning achievement between public and private schools increases with income.

Figure 29: Public/private enrollment by socio-economic quintile, 2013

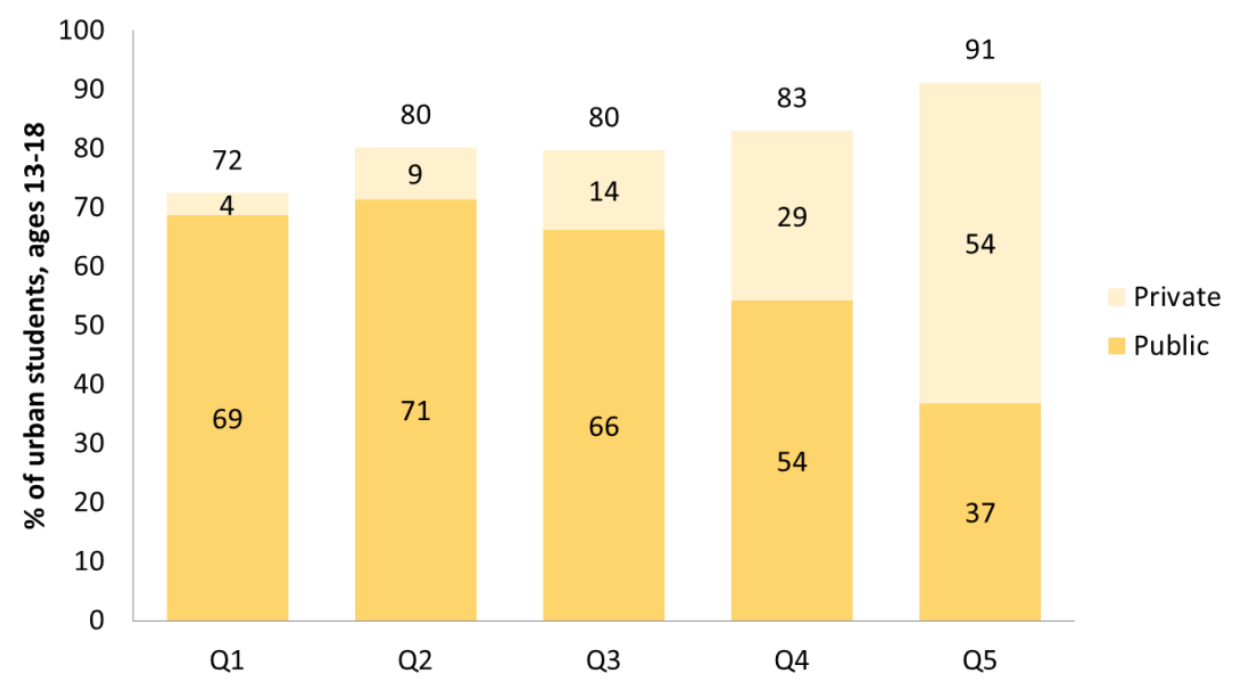

Source: World Bank SSEIR team's analysis of household surveys, authors' calculations using standardized ADePT software (Education Module)

Insufficient school readiness and poor teacher quality are some of the main constraints to achieve a higher quality public education. Patrinos et al. (2013) propose a framework to understand the factors that can increase education quality. Improvements in learning outcomes require a systematic approach where both elements of structural quality and institutional factors are considered. Among the former, school readiness, teacher quality and attention to local culture within the curriculum are key determinants of students' achievements. ${ }^{7}$ Among the latter, quality of the

\footnotetext{
${ }^{7}$ Recent evidence both for the LAC region (Bruns et al., 2013) and for the US (Chetty et al., 2013) also provide evidence that teacher quality is an important driver of success both during the school career and in the labor market.
} 
assessments, stakeholders' autonomy and a system of accountability in place have been proven to have a positive effect on learning. Both in terms of structural quality and institutional factors, the education system in El Salvador suffers from significant gaps. First, the country does not collect data on child development, but the existing information does suggest that children, especially those from the lowest socioeconomic background, enter in school with already large gaps. According to the information collected in the 2013 household survey, only 45 percent of the children age 7 in the first consumption quintile are able to read, as opposed to the 83 percent among children in the highest quintile (Figure 30). Second, the improvement of teacher quality is one of the main challenges for the education system in the country. In 2000, the Government of El Salvador established a mandatory exam for teachers exiting teacher training programs, called the Evaluacion de las Competencias Académicas y Pedagógicas (ECAP). Although the fraction of teachers passing the ECAP has dramatically increased over time-passing from roughly 40 percent in 2001 to almost 80 percent in 2012 - the teachers attending training programs represent a minority of the entire teaching corps so far. Third, the curriculum has not been traditionally linked to the local culture and the need of the local labor markets, thus creating a gap between the demand and the supply of relevant skills.

Figure 30: Proportion of 7 year old who can read by quintile, 2013

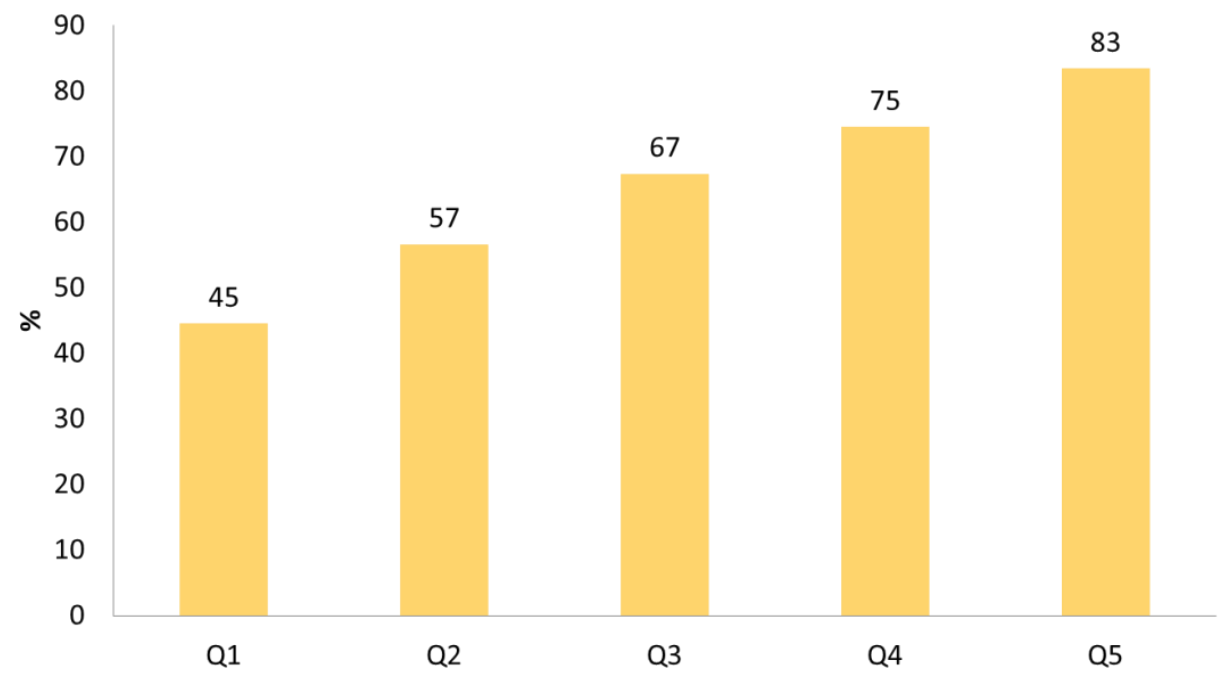

Source: World Bank SSEIR team's analysis of household surveys, authors' calculations using standardized ADePT software (Education Module)

\section{III.3 Institutional reforms and challenges}

The School-Based Management (SBM) system has been disproportionally focused on monitoring financial resources, and very little on quality standards. As a result of the implementation of the EDUCO system back in 1991, which only recently has been phased out, El Salvador has been long regarded as a laboratory of the SBM in the region. In EDUCO schools, the Asociación Comunal para la Educación (ACE), or Community Education Association, whose members are elected from among the parents of the students, has a central role in school administration and 
management. The EDUCO system achieved significant results in extending school coverage in rural areas and reducing school drop-out rates (Jimenez, 2014). However, the accountability system was focused almost exclusively on financial resources. While this feature contributed to the reduction of teachers' absenteeism, it left very little space for quality standards. The creation of parents and community organizations favored the involvement of these two actors in school management. Nevertheless, the system was unable to achieve an effective empowerment of the actors. For instance, the role of school principals as pedagogical leaders was never fully defined. Teachers were not adequately trained for content or pedagogical learning styles. Parents and community associations were not provided with the skills to monitor and provide feedback on teachers' quality. All these elements combined can explain why the EDUCO system did not lead to improvements in the quality of learning. The assessment model might potentially rely on already very rich administrative sources of data, such as the results from the standardized tests (PAES and PAESITA) and annual school census data; unfortunately, there are still gaps in the data collected. The data is also rarely provided in a timely matter to policymakers/teachers/principals so that it can actually support the decision making process.

Today, the new full-time school (FTS) model builds on a strong territorial strategy to promote quality. Started by the previous administration as a pilot in primary schools in selected municipalities, the scale-up of the FTS model became the main education policy of the previous government and has continued to be a priority in the current administration (Figure 31). As part of the territorial strategy, schools within a given municipality are reorganized to form clusters, within which they share and are governed by a unique governance and administration system. ${ }^{8}$ Each cluster of schools aims to provide a full set of school services, ranging from preschool to upper secondary levels. Besides the improved supply of school services, the FTS model promotes greater collaboration across schools, leveraging equipment, resources, teachers, and expertise within clusters. More than the mere extension of the school day, the FTS reform focuses on new pedagogical approaches in the classroom to increase student learning, provide for the professionalization of the teaching career path, and install a more robust monitoring and evaluation information system. More time is allocated to learning, as the instructional time increases from 25 to 40 hours per week. The additional time is devoted to traditional subjects as well as to new ones, such as music, art \& crafts, etc. The inclusion of additional subjects is part of a new and broader education model, valuing an extended set of competencies and values (e.g. citizenship). The contents and the pedagogical practice, unlike the previous model, are expected to be more in line with the characteristics of the surrounding community.

\footnotetext{
${ }^{8}$ The ODEI, the Organismo Directivo de la Escuela Inclusiva, is the most important governing body.
} 
Figure 31: Organizational Structure of the FTS Model

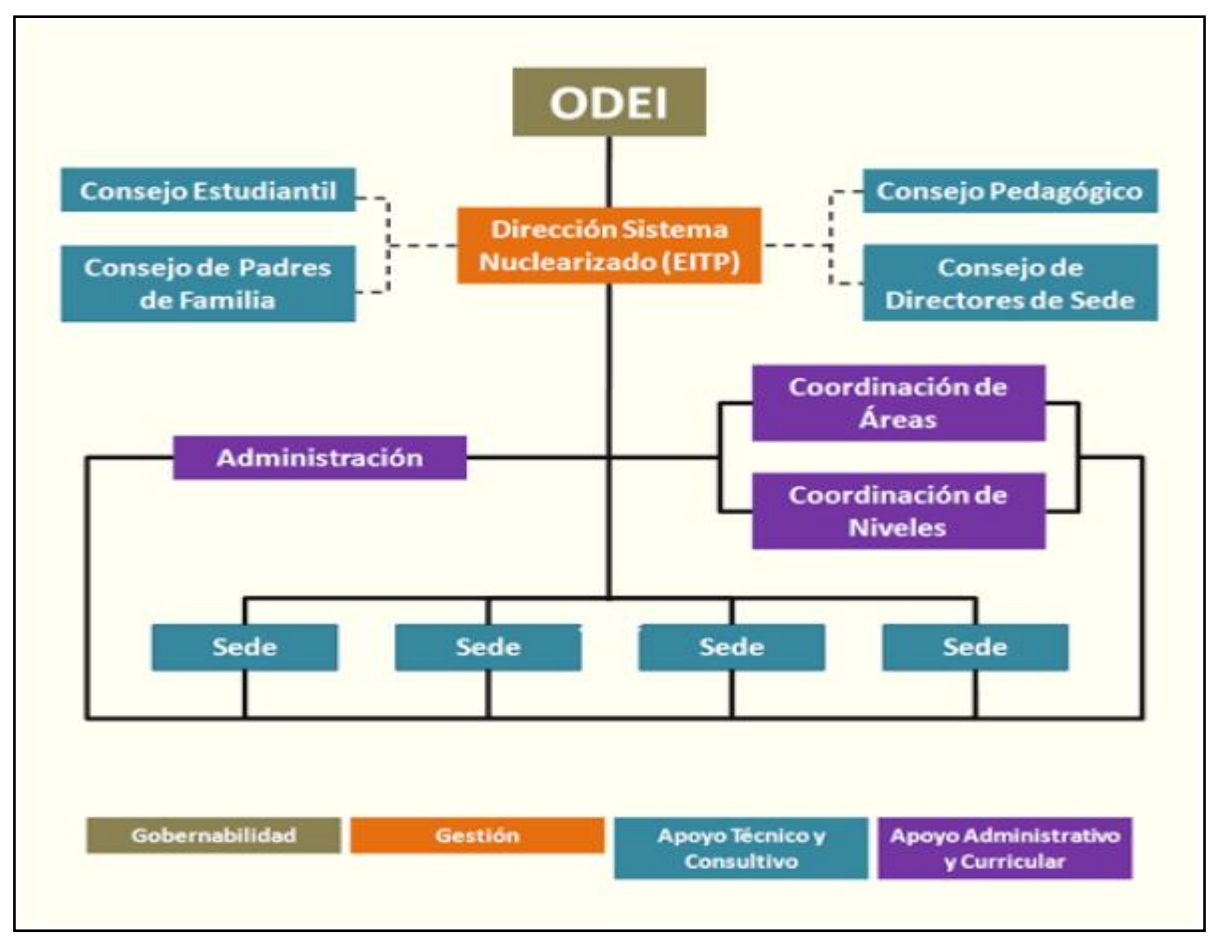

The full-time school model emphasizes the training of different actors, but sustainability is the main challenge. The training aims at providing teachers with the ability to align didactic plans, teaching practices and pedagogical plans to the grade/subject they teach. The training program for school principals will aim at improving their ability to be both effective managers and pedagogical leaders. The weakest area of the training model is the focus on the parents and community. For them, training is meant to give them only information about the full-time model (the induction phase, in Spanish referred to as "las fases de inducción") and will therefore not train them to become more active and engaged advocates in their children's education. Looking ahead, with the expansion in access and eventually lower student-teacher ratios, there will be further pressures on the teacher wage bill (see Bruns et al., 2013). These pressures will be reinforced further by the additional teaching hours required by the expansion of full-time school model. In the medium term, the dual areas of quality and financing of this model will require particular attention and analysis. 
El Salvador Social Expenditure and Institutional Review

\section{Performance and Challenges in Health}

\section{IV.1 Recent Evolution of Public Spending on Health}

El Salvador's public spending on health has increased over time and is in line with most Central American countries. While its share of government health spending relative to GDP between 2007 and 2013 increased (3.4 percent - 4.3 percent), it remains in line with other Central American countries except Costa Rica (Figure 32). Same situation arises in terms of per capita public spending, at higher levels than Guatemala, Honduras and Nicaragua but well below Costa Rica and Panama (Figure 33).

Figure 32: Public Spending on Health as a $\%$ of GDP by countries

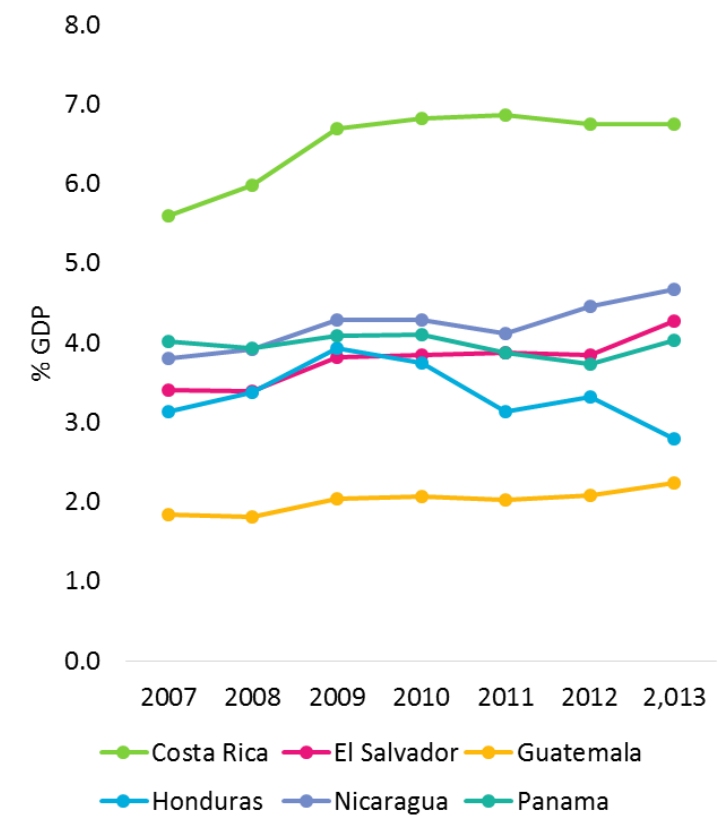

Source: World Bank SSEIR/ICEFI social spending database
Figure 33: Per capita public spending on Health by countries (real, US\$2007)

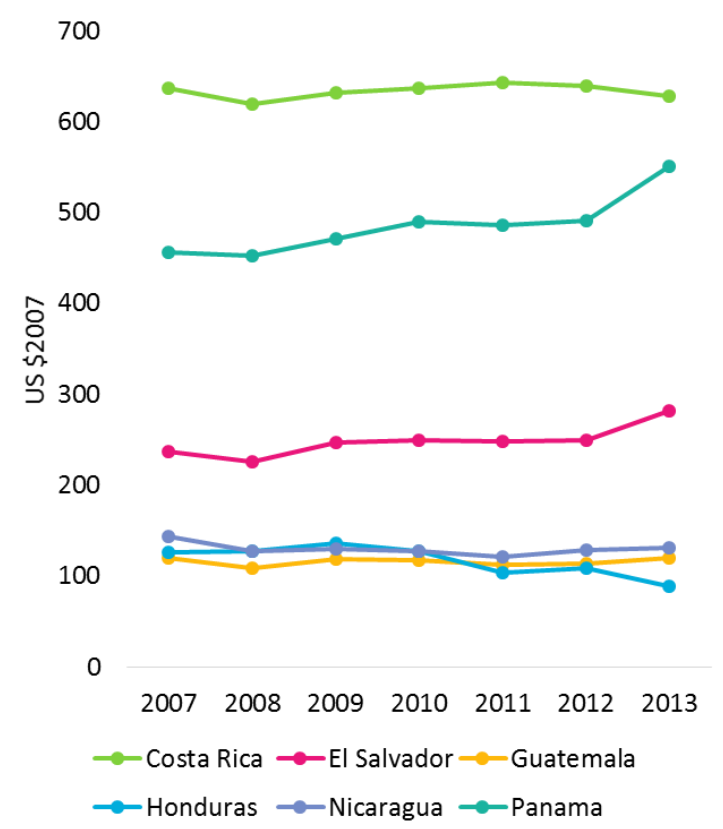

Source: World Bank SSEIR/ICEFI social spending database

During the same period, public expenditures on health steadily increased while private expenditures on health decreased. Increased public spending on health was accompanied over time by lower private spending on health, a significant share of which was comprised by reductions in out of pocket spending (Figure 34). This trend most likely reflects the increased budget allocation to health and the impact of the public policy that abolished fees for health services ${ }^{9}$ in the country.

\footnotetext{
${ }^{9}$ Free access to health services applies to all levels of care, with an emphasis on primary health services. Policy
} implementation started in 2010 . 
El Salvador Social Expenditure and Institutional Review

\section{Figure 34: Public, Private, and Out of Pocket expenditure as \% of Total Health} Expenditure: 2000 to 2011

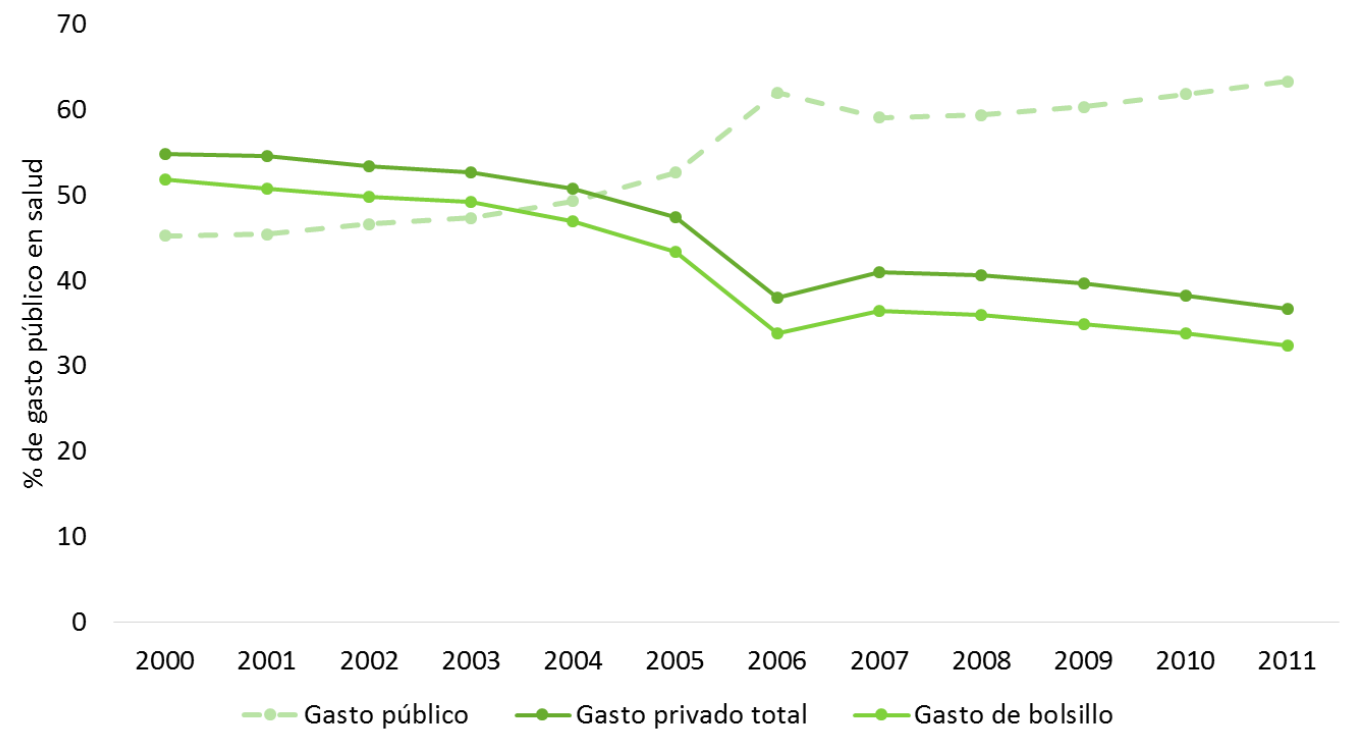

Source: MOH National Health Accounts 2012

Household expenditures decreased from 2007 to 2013 with most spending allocated to medicines and other health items/services. Household survey data show that the share of health out of pocket expenditures as a share of total household expenditures decreased from 2.8 percent from 2008 to 2 percent in 2013, with most spending allocated to medicines and other health expenditures (glasses, dentists). Households' out of pocket spending went mostly to drugs and other health expenses (lenses, dentists, etc.) for all expenditure quintiles (Figure 35). While the poorest quintile allocated the largest share of its expenditures to drugs, the highest quintile allocated the largest share of their spending on other health services/items such as lenses and dentists. In addition, out of pocket spending in private hospitals also decreased for almost all expenditure quintiles (Figure 36). With the exception of households in the fourth expenditure quintile which only experienced a very small increase, the rest of the households " out of pocket costs in private hospitals declined, in particular for those at the highest expenditure quintile. 
El Salvador Social Expenditure and Institutional Review

Figure 35: Household Health Expenditure Shares by Health Expenditure Category and by HH Income Quintile, 2013

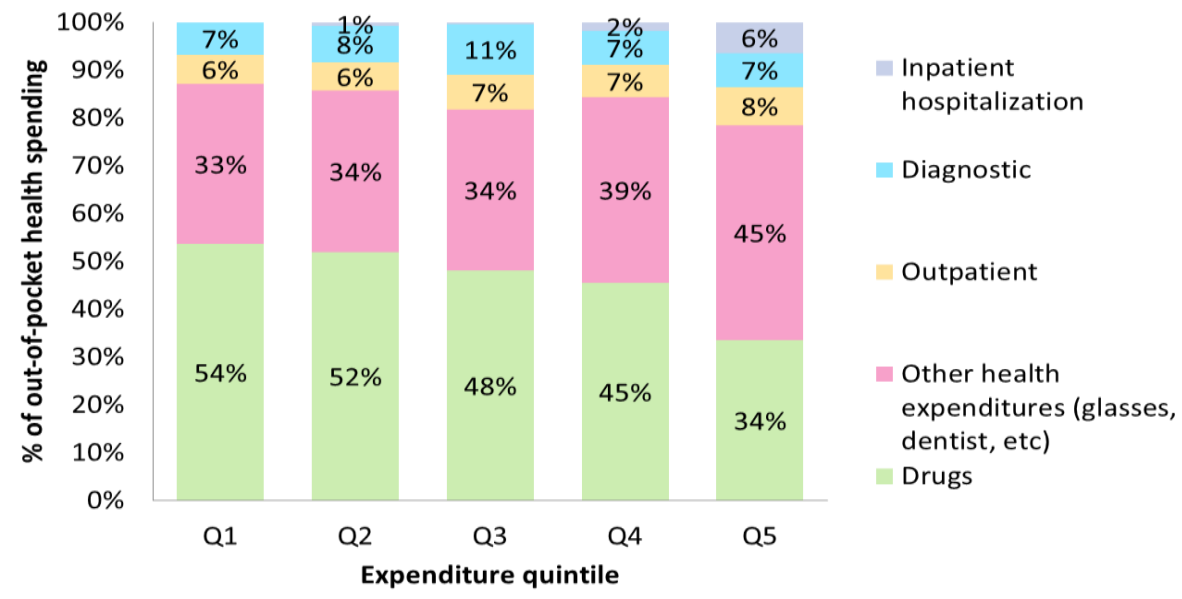

Source: World Bank SSEIR team's analysis of household surveys, authors' calculations using standardized ADePT software (Health Module)

Figure 36: Out-of-pocket spending by expenditure quintile, 2008-2013

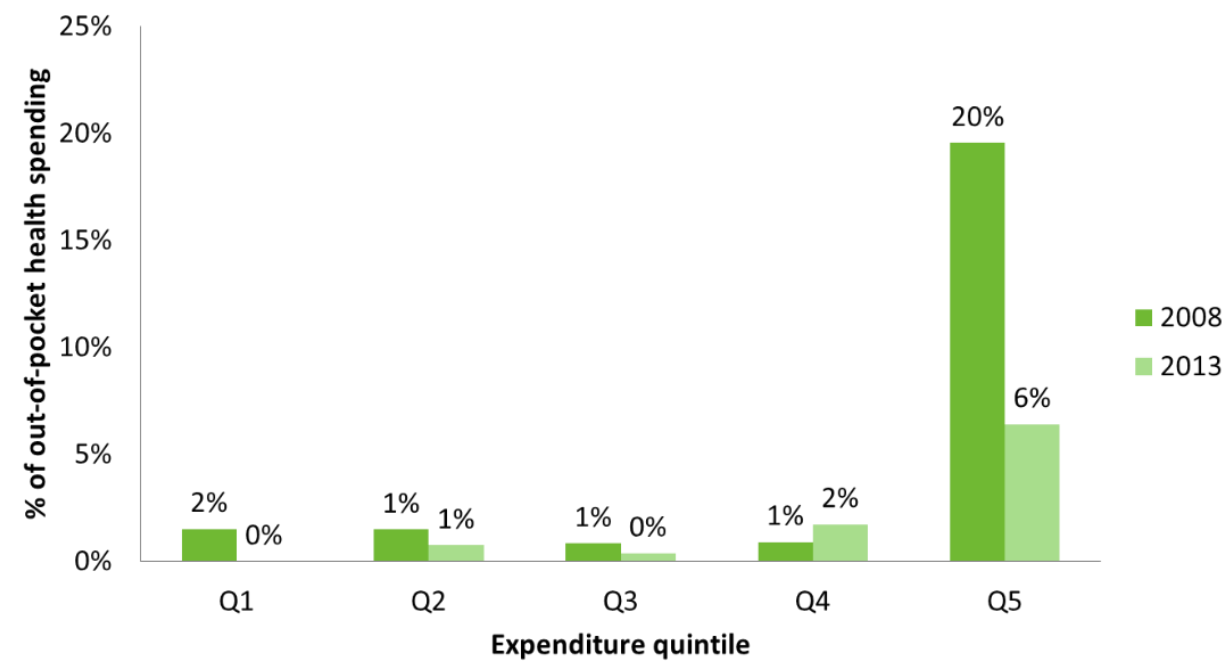

Source: World Bank SSEIR team's analysis of household surveys, authors' calculations using standardized ADePT software (Health Module) 
Among public sector institutions, the Ministry of Health (MOH) accounted for majority of public spending on health. As the main public sector institution responsible for providing health care in the country, the Ministry of Health had the largest share of total public spending on health (slightly over 50 percent), followed by the ISSS (41 percent) (Figure 37). The Salvadorian Institute of Teachers' Wellbeing (ISBM), Solidarity Fund for Health (FOSALUD), Military (COSAM), Superior Council of Public Health (CSSP), Salvadorian Institute of Handicap Rehabilitation (ISRI), Red Cross and National Directorate of Medicines (DNM) accounted for the remaining 9 percent of public spending on health. But while $\mathrm{MOH}$ has the largest nominal coverage rate of the Salvadorian population (75 percent), its increase in spending from 2007 to 2013 was lower than the spending increase of four other public health institutions that have significantly lower coverage rates. Although the Ministry of Health's spending increased by 9 percent, this spending increase was less than the spending increases (each greater than 45 percent) of ISBM, FOSALUD, COSAM and DNM.

Figure 37: Public expenditure in health by Institution. E1 Salvador, 2007- 2013

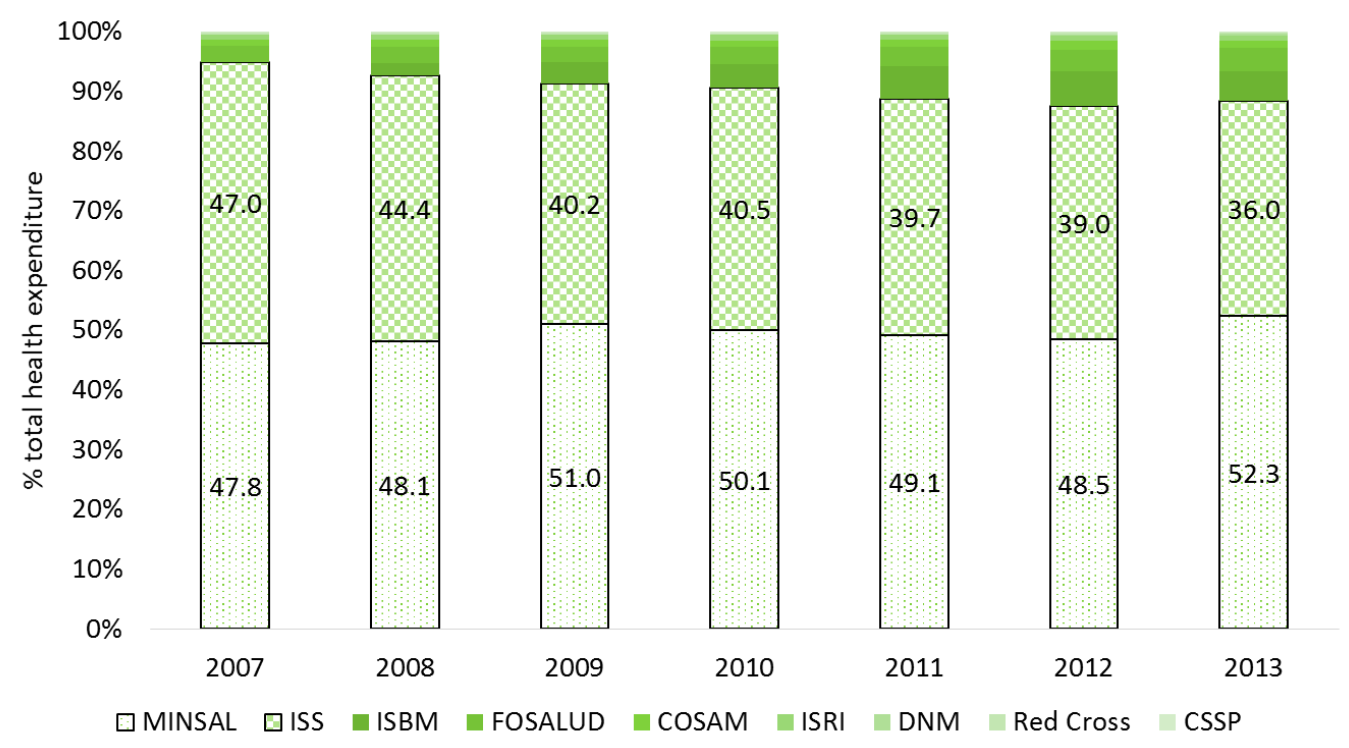

Source: World Bank SSEIR / ICEFI social spending database

Despite efforts improve service delivery and better target the poor, public provision of health care remains fragmented, with inequities in spending by different providers. This is reflected in the significant differences in per capita expenditures among different public providers ( 
El Salvador Social Expenditure and Institutional Review

Figure 38). In 2013, per capita expenditures ranged from US $\$ 137$ by the Ministry of Health, US $\$ 236$ by ISSS, US $\$ 349$ by COSAM, up to US $\$ 508$ by ISBM. Similar disparities existed since 2007.

Figure 38: Per capita spending on health by Institution in El Salvador: 2007-2013

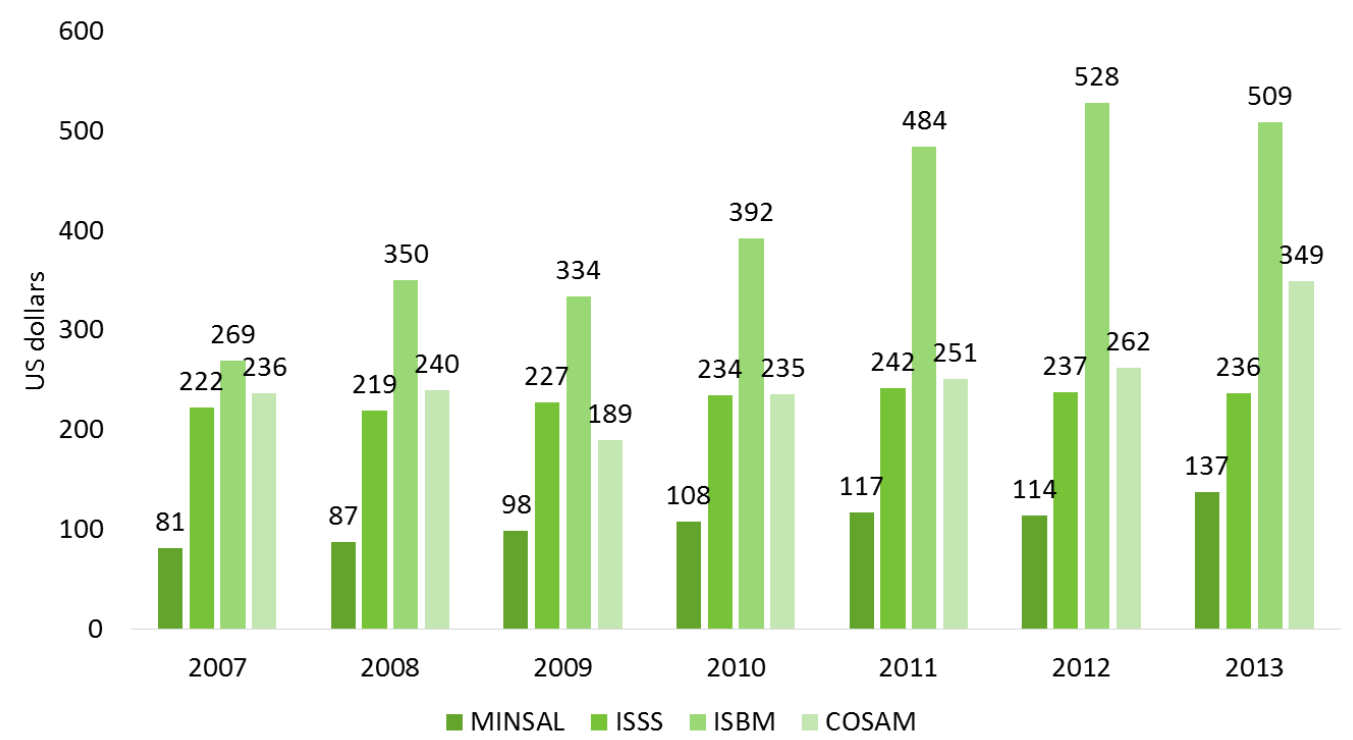

Source: World Bank SSEIR / ICEFI social spending database

Salaries represent the largest share of $\mathrm{MOH}$ expenditures while average spending on supplies remained low. From 2007 to 2013, MOH spending on salaries ranged from 58.2 to 59.4 percent, averaging 57.7 percent while spending on medicines decreased and spending on supplies 
marginally increased (Table 2). The MOH's salary expenditure share is higher than the average share of wages out of total health spending in middle income countries ( 52 percent). ${ }^{10}$ In terms of CA countries, it is lower than the share allocated by the $\mathrm{MOH}$ to salaries in Honduras (60.5 percent) but higher than Guatemala's MOH salary share (48 percent). ${ }^{11}$ The relatively low average share of expenditures on supplies (5.3 percent) explains the lack of medical supplies in health facilities, as well as the slow replacement of equipment. The assessment of the delays in achieving MDG5 (reducing maternal mortality) identified the lack of supplies as having a direct impact on the services provided to pregnant women during institutional delivery. ${ }^{12}$

Table 2: Ministry of Health Expenditures by selected expenditure categories: El Salvador, 2007-2013

\begin{tabular}{|l|r|r|r|r|r|r|r|}
\hline & 2007 & 2008 & 2009 & 2010 & 2011 & 2012 & $2013 \mathrm{p}$ \\
\hline Total Budget (million US\$) & 371.4 & 399.3 & 458.9 & 486.4 & 553.9 & 561 & 625.5 \\
\hline Percentages & & & & & & & \\
\hline Salaries & 58.2 & 58.9 & 55.2 & 56 & 55.9 & 60.4 & 59.4 \\
\hline Medicines & 10.4 & 7.2 & 10.8 & 11.8 & 6.8 & 7.2 & 6.8 \\
\hline Vaccines & 1.2 & 2.1 & 1.8 & 1.8 & 3.4 & 2.6 & 2.3 \\
\hline Medical and Laboratory supplies & 5.1 & 4.4 & 6.6 & 5.1 & 5.6 & 6.1 & 5.3 \\
\hline Other Recurrent expenditure & 11.6 & 13.9 & 14.6 & 15 & 15 & 14.4 & 12.4 \\
\hline Capital & 13.4 & 13.6 & 11.1 & 10.3 & 13.3 & 9.2 & 13.8 \\
\hline Total Budget & 100 & 100 & 100 & 100 & 100 & 100 & 100.0 \\
\hline
\end{tabular}

Source: Ministerio de Salud Publica. Informe de Labores.

The largest share of public expenditures in health went to hospital services, in line with the average CA share of spending on hospitals. From 2007 to 2013, the average pending on hospital services represented approximately 48 percent of public health expenditures which is close to the average of 49 percent for five CA countries, followed by outpatient services with an average share of 35 percent and then non-specified expenditures which averaged approximately 14 percent. ${ }^{13}$ Both expenditure shares for hospitals and outpatient remained constant from 2007 to 2013 (from 47 percent to 46 percent in the case of hospitals and from 35.2 percent to 34.7 percent in the case of outpatient services). On the other hand, non-specified expenditures increased from 15 percent to 17 percent in 2013. Spending on research and development was less than 1 percent. ${ }^{14}$

${ }^{10}$ Clements et al (2010).

$11 \mathrm{MOH}$ in Guatemala (2012)

12 Ministerio de Salud and Sistema de Naciones Unidas de El Salvador (2012)

${ }^{13}$ The CA average for 5 countries was 48 percent; disaggregated spending by facility level was not available for Costa Rica.

${ }^{14}$ ICEFI and COFOG 


\section{IV.2 Results and Outcomes}

Higher public spending on health and the elimination of fees-for-service has had a positive impact on health care use in El Salvador. Consultations increased, particularly at the primary level of care, after the policy was introduced (Figure 39).

Figure 39: Health Care visits by level of Care. E1 Salvador, 2008-2012

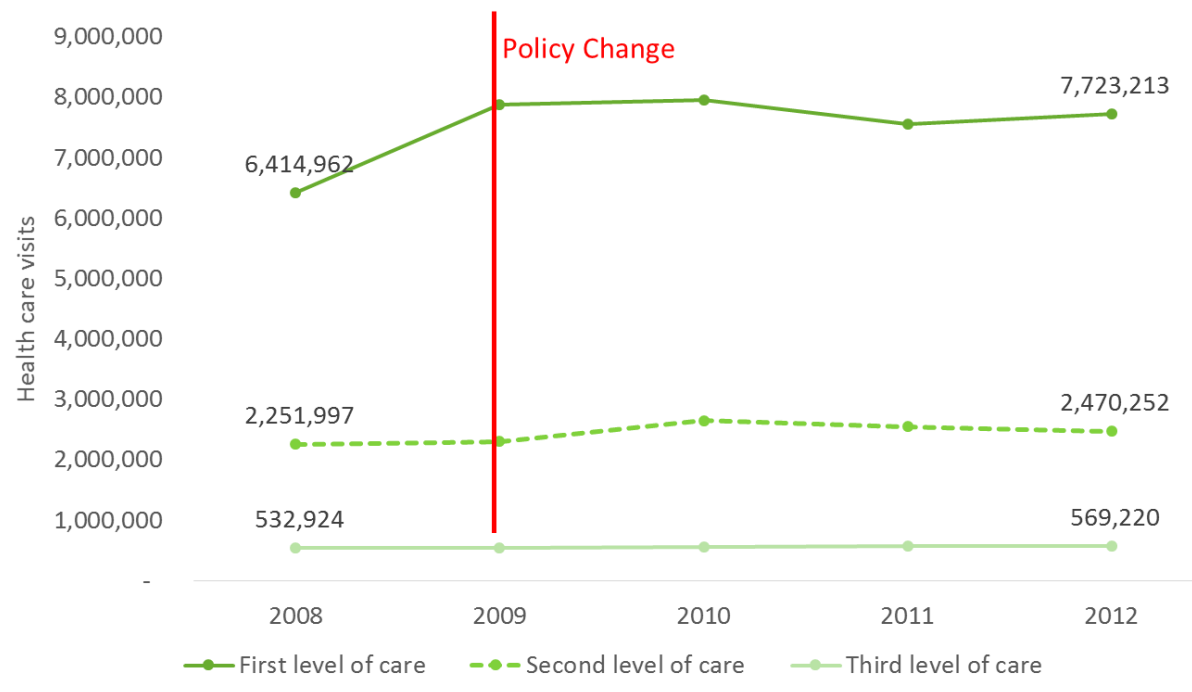

Source: Ministerio de Salud Publica. Informe de Labores.

Moreover, a larger share of people seek health care when they are sick than in previous years, but 40 percent still do not do so even when ill. Household survey data confirm that the percentage of those with reported illness who did not seek care decreased across all expenditure quintiles from 2008 to 2013 (Error! Reference source not found. and Error! Reference source not found.). Despite the increase in health seeking behavior, around 39 percent of those who declared themselves sick did not seek care in 2013, with 46 percent of the households in the lowest expenditure quintile not seeking care compared with 31 percent in the highest expenditure quintile (Error! Reference source not found.). From 2008 to 2013, households in the lower two expenditure quintiles that sought care at public health facilities increased by approximately 8 percentage points while households in the highest expenditure quintile that sought care at public health care facilities increased by more than 10 percentage points. 
Figure 40: Utilization of health facilities by Figure 41: Utilization of health facilities by quintile, 2008 quintiles, 2013

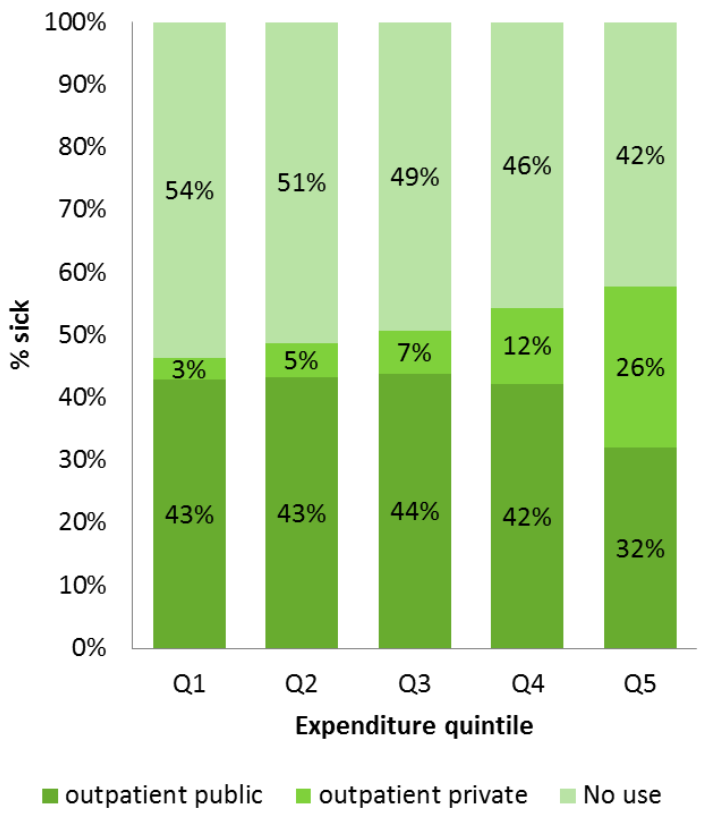

Source: World Bank SSEIR team's analysis of household surveys, authors' calculations using standardized ADePT software (Health Module)

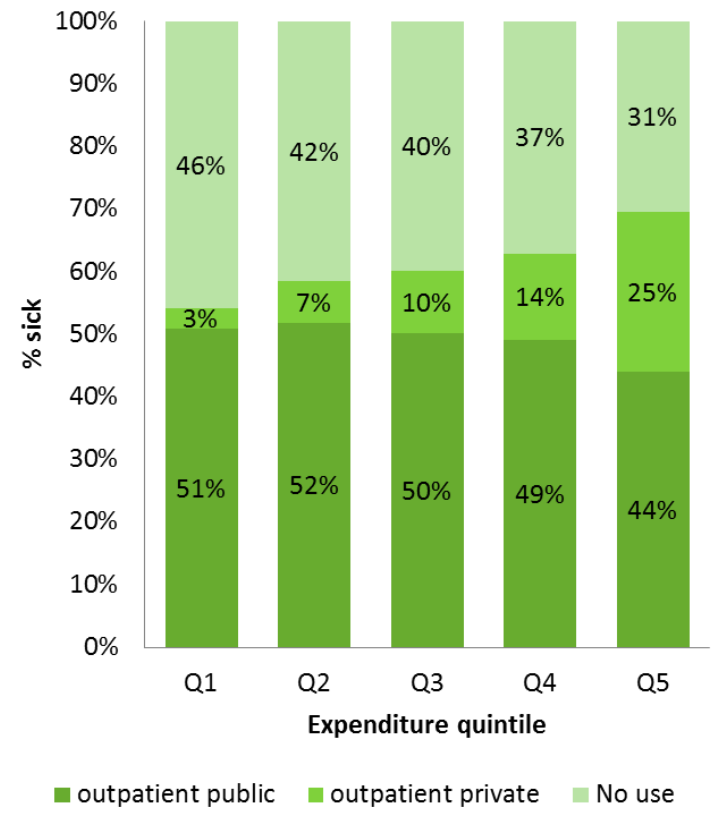

Source: World Bank SSEIR team's analysis of household surveys, authors' calculations using standardized ADePT software (Health Module)

From 2008 to 2013, use of public hospitals has remained high for all expenditure quintiles. While all households in the lowest expenditure quintile continued to only use public hospitals, even households in fifth quintile increased their utilization of public hospitals from 64 percent in 2008 to 71 percent in 2013 (Figure 42 and Figure 43). 
Figure 42: Place of hospitalization by Figure 43: Place of hospitalization by expenditure quintile, 2008

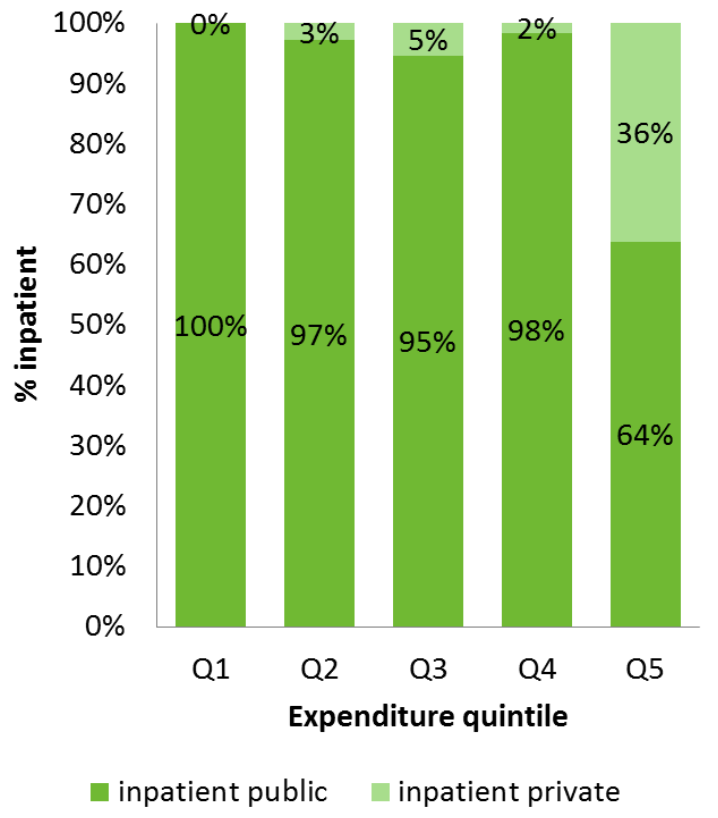

Source: World Bank SSEIR team's analysis of household surveys, authors' calculations using standardized ADePT software (Health Module) expenditure quintile, 2013

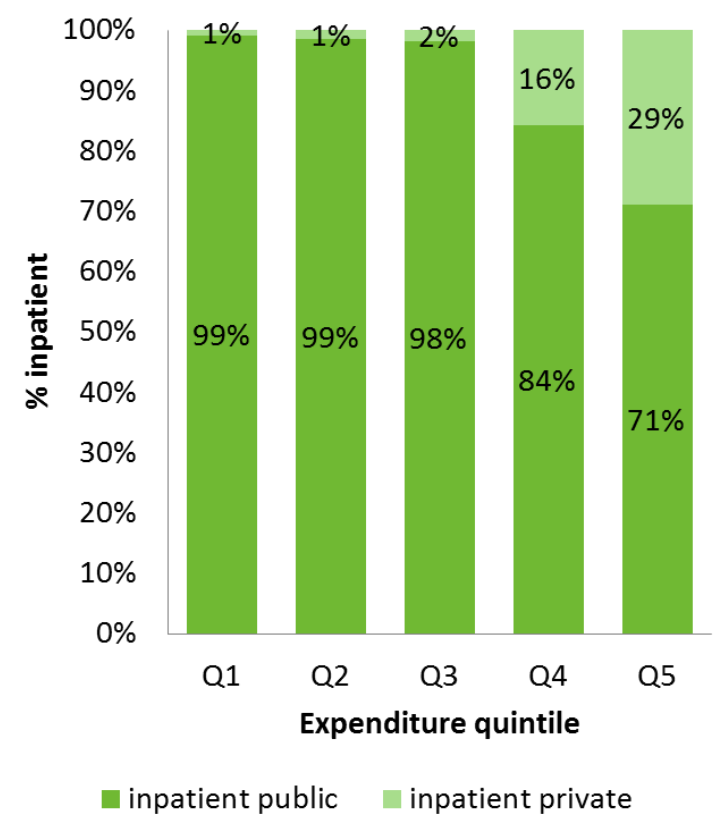

Source: World Bank SSEIR team's analysis of household surveys, authors' calculations using standardized ADePT software (Health Module

Importantly, increased public spending on health and health care utilization have contributed to improvements in health outcomes. From 1990 to 2013, El Salvador significantly reduced its under-5 mortality rate, achieving its MDG 4 Goal (Figure 44Error! Reference source not found.). However, despite progress in reducing deaths in young children, neonatal mortality (the number of children dying before reaching 28 days of age per 1,000 live births) comprises 66 percent of the deaths in children under one year of age. To reduce mortality in this age group, El Salvador would need to invest in technology and preventive care for women with high risk of having complications during delivery and/or having low birth weight infants. 
Figure 44: Maternal and child mortality trends, E1 Salvador 1990-2015

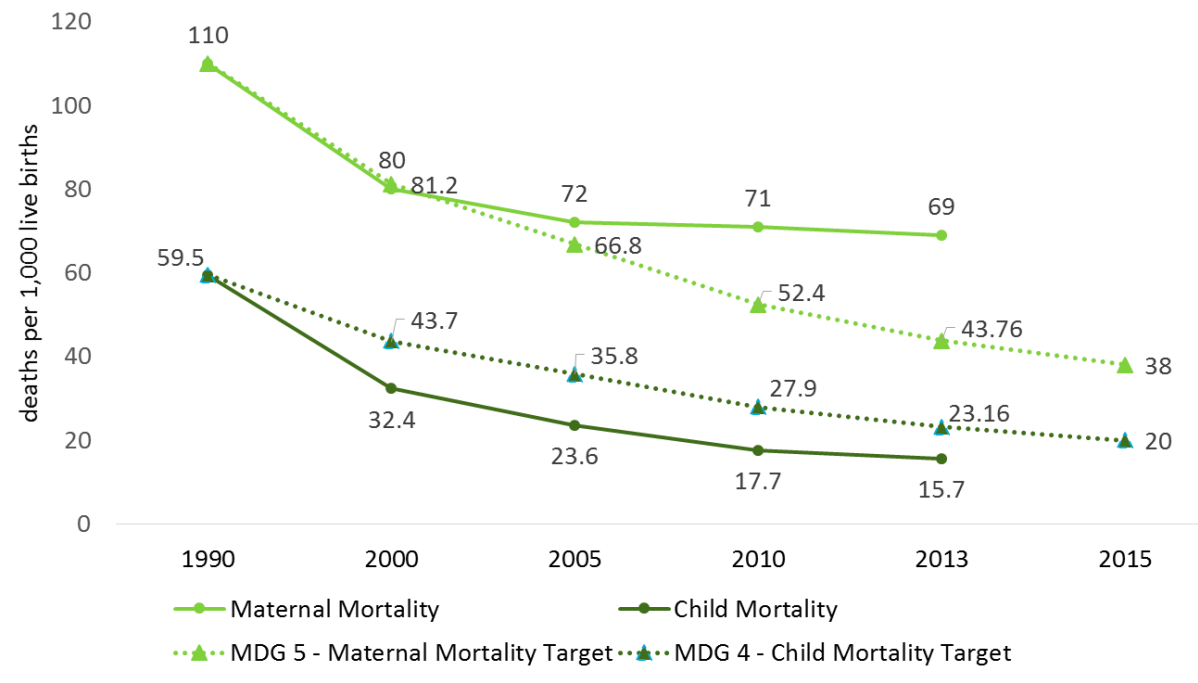

Source: WDI 2013

Despite progress in reducing maternal mortality, El Salvador does not seem to be on track to achieve its MDG 5 goal. Maternal mortality decreased from 110 deaths in 1990 to 69 deaths per 100,000 live births in $2013^{15}$ (Figure 44). In 2013, adolescents accounted for 31 percent of maternal mortality. Most maternal deaths (60 percent to 97.5 percent) are considered preventable. Skilled specialized assistance during deliveries has been reported for 83.7 percent of births yet maternal mortality remains relatively high indicating that, although coverage has improved, quality of care has not kept pace. Moreover, the average mortality and infant mortality rates hide significant disparities within the country which, in turn, reflect disparities in the distribution of resources, coverage and the quality of health care provided in urban relative to rural areas. Neonatal and maternal mortality rates are higher in municipalities with a low Human Development Index (HDI); half of neonatal deaths and two thirds of maternal deaths are in rural areas.

Despite improvements in key indicators, efforts are still needed to address maternal and child health issues. In an effort to meet the MDGs targets, the Government subscribed to implementing the MDG Accelerated Framework (MAF) with a focus on maternal mortality. The effort, supported by UN agencies and the WB expects to focus on the most disadvantaged groups and achieve defined targets during the time left before December 2015. The objective of the MAF in El Salvador is to strengthen MOH capacity to deliver integrated maternal, neonatal and reproductive health including risk management for women in pregnancy, puerperal and neonatal stages, that lives in 3 pre identified health regions, during the period February 2014 to December 2015. The plan components include: Food safety and Nutrition, accessibility to services, increased access to

\footnotetext{
15 Maternal Mortality Data taken from the World Development Indicators (WDI). These estimates differ slightly from those in "Trends in Maternal Mortality 1990 to 2013" published in 2014 by WHO, UNICEF, UNFPA and The World Bank (http://whqlibdoc.who.int/publications/2012/9789241503631_eng.pdf). However the trend and conclusions are the same, independently of the source of data used.
} 
education and supplies for sexual and reproductive health (SRH) including the hospital level, ensure quality of care, promote research and strengthen surveillance.

Additional interventions are also required to respond to E1 Salvador's changing epidemiological profile. Chronic diseases and trauma/accidents (including violence) have emerged as among the main reasons for outpatient consultation, as well as among the top ten causes of death in the country (Table 3). This information is in line with the reports of the rising number of outpatient visits for diabetes and hypertension. Health resources are being used to treat these illnesses although resources could be better allocated to their prevention. Multi-sectoral actions are needed. For example, violence which impacts directly and indirectly on the national health system, for example, from pregnant women experiencing difficulties to reach the health facilities up to emergency health facilities filled with cases of domestic and street violence, would require a set of coordinated interventions from different national institutions beyond the regulatory/legal framework.

Table 3: Ten most frequent causes of mortality at the MOH Hospitals. El Salvador, January- December 2012

\begin{tabular}{rlcc}
\cline { 2 - 4 } 1 & Mortality causes- CIE-10 & Number & Percentage \\
\cline { 2 - 4 } 2 & Diseases of the Genito-Urinary System $^{16}$ & 876 & 8.74 \\
3 & Cerebrovascular Diseases & 618 & 6.17 \\
4 & Cardiovascular Diseases & 578 & 5.77 \\
5 & Diabetes Mellitus & 560 & 5.59 \\
6 & Diseases of the Digestive System & 488 & 4.87 \\
7 & Perinatal Infections & 483 & 4.82 \\
8 & Cranel trauma & 461 & 4.60 \\
9 & Other cardiac disease & 456 & 4.55 \\
10 & Liver Diseases & 436 & 4.35 \\
& Other causes & 436 & 4.35 \\
& Total & 4601 & 45.90 \\
\cline { 2 - 3 } Source: $\mathrm{MOH}$ & 10024 & 100.00 \\
\hline
\end{tabular}

\section{IV.3 Institutional Reforms and Challenges}

The Government developed a National Health Strategy in 2009, with eight areas of defined interventions that have been partially implemented. In particular, two main policies related to access are being implemented in the public health system. First, the Government implemented the policy of free access to health care at the public health facilities network all over the county in 2010

\footnotetext{
16 These conditions relate to the genital and urinary organs or functions. Some common diseases that fall in the Genitourinary category are Gonorrhea, HPV, Urinary tract infections, kidney failure, Chlamydia, and E. coli.
} 


\title{
El Salvador Social Expenditure and Institutional Review
}

(Box 1). Second, it has been prioritizing actions to reduce child and maternal mortality rates, addressing the challenges of populations at risk, especially adolescents, youth, and other highly social excluded population groups through the strengthening the coordination of the levels of care provision in the public system. This strategy, known as the Integral and Integrated Health Network (RIIS), supports the strengthening of coverage of health services through the implementation of Family Community Teams (ECOS). ECOS are health teams that visit the rural areas to provide health care at the household level with general as well as specialized care. It is considered innovative because it harmonized the way primary health care was delivered, especially in poor rural areas. Previously these health services were provided by NGOs, which were more costly and less harmonized especially with the rest of the health system.

\section{Box 1: Removal of User Fees in El Salvador}

\begin{abstract}
On June 1st, 2009, a new Government with a different political orientation, assumed office after 20 years of the same party governing the country. During the second half of 2009, this new Government outlined the social policy and strategic lines of its development plan centered around the development of an Universal Social Protection System which covers: urban and rural solidarity-communities, temporary income support program, universal basic pension and elder-adult integral program; actions directed to the vulnerable populations, increasing social security coverage and the establishment of a single beneficiary registry. In this context, the Ministry of Health $(\mathrm{MOH})$ formulated its Health Policy and strategies for its implementation, which included the elimination of user fees in all $\mathrm{MOH}$ managed health care facilities. This policy was complemented by the creation of the Network of Integrated Health Care Services (RIIS), expanding and promoting the integration of health coverage to the population.

Source: WHO/PAHO. Country Cooperation Strategy at Glance. 2010; Ministerio de Salud Publica. Informe de Labores 2012-2013.
\end{abstract}

By 2013, 517 ECOS have been deployed in 62 percent (164) of the country's municipalities. The ECOS mobile health teams have increased service coverage and helped to solve overcrowding in hospitals in some regions. However, the sustainability of this model is at stake because it has not been considered in the budget planning or budget projections and it is partially funded by international partners. In addition the ECOS mobile health teams are relatively larger (eight to twelve persons) than the usual two to four health professionals of other traditional mobile community teams. 
However, other areas of the Government's health strategy, such as the establishment of an integrated health care system that supports coordinated health care services in the country, have not been implemented. Although an agreement was drawn up between the ISSS and the $\mathrm{MOH}$ in order to establish the mechanisms in which the MOH and the ISSS could work together to address the needs of the insured and uninsured population, more work needs to be done to improve sectoral coordination. To date, the National Health System remains highly fragmented (Box 2), comprised by overlapping networks of health care facilities providing health care services to different groups of the population according to their affiliation, capacity to pay and insertion in the formal labor market. Duplication of services also seems to coexist in the case of FOSALUD, ISSS, ISBM and COSAM. ${ }^{17}$ In addition, FOSALUD acts more as a parallel system to the MOH instead of an entity to complement it, resulting in budget inefficiencies in the public sector.

\section{Box 2: Integration of the National Health System in El Salvador: A Future Goal}

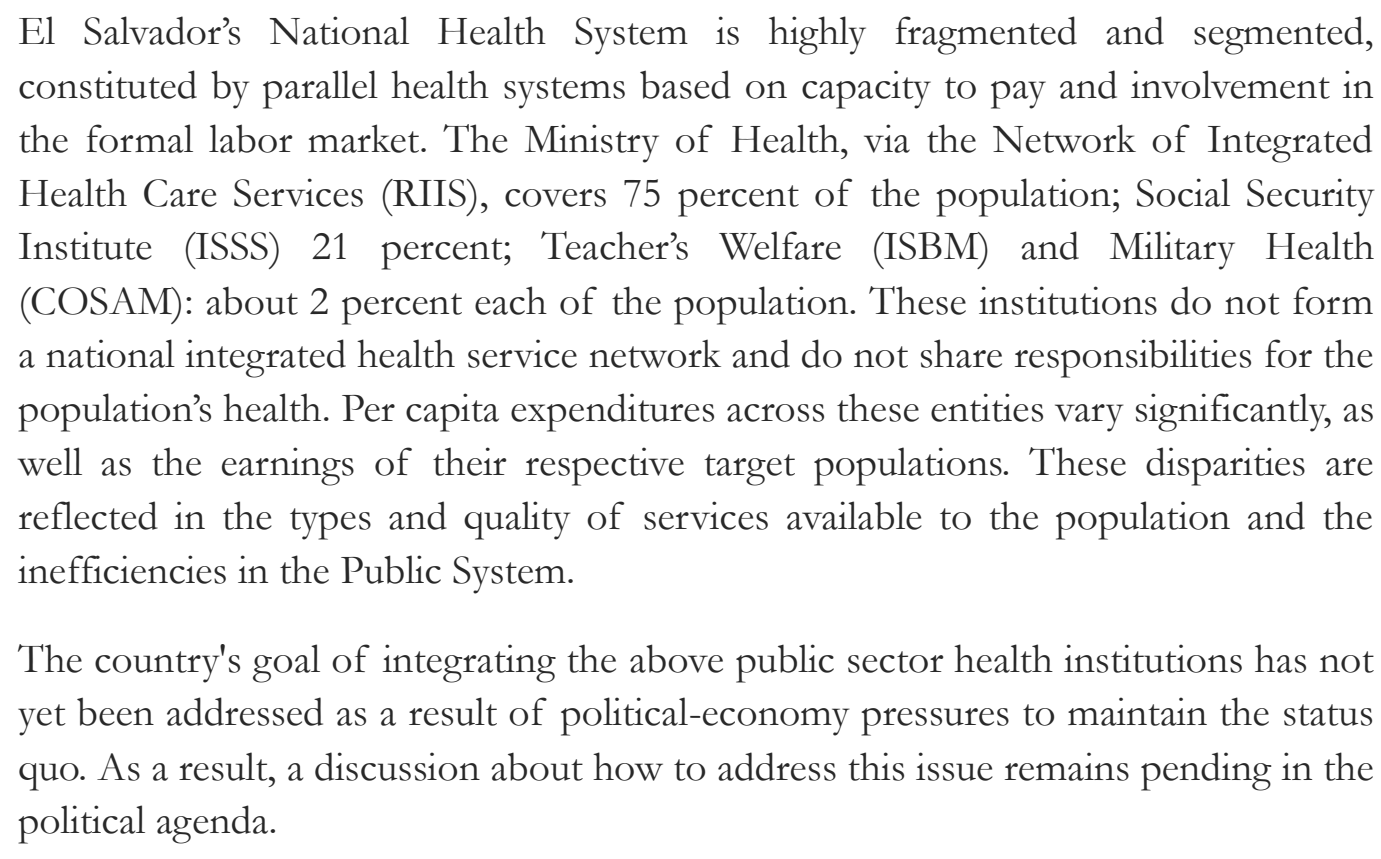
constituted by parallel health systems based on capacity to pay and involvement in the formal labor market. The Ministry of Health, via the Network of Integrated Health Care Services (RIIS), covers 75 percent of the population; Social Security Institute (ISSS) 21 percent; Teacher's Welfare (ISBM) and Military Health (COSAM): about 2 percent each of the population. These institutions do not form a national integrated health service network and do not share responsibilities for the population's health. Per capita expenditures across these entities vary significantly, as well as the earnings of their respective target populations. These disparities are reflected in the types and quality of services available to the population and the inefficiencies in the Public System.

The country's goal of integrating the above public sector health institutions has not yet been addressed as a result of political-economy pressures to maintain the status quo. As a result, a discussion about how to address this issue remains pending in the political agenda.

Over time, the Government has developed its stewardship role and improved the regulatory environment in El Salvador. For example, the Government introduced several regulatory measures to improve sexual and reproductive health rights which led to the creation of the Unit for Stigma and Discrimination Claims, and continues to support a Pharmaceutical Law which was

17 Pineda, 2012 
approved in 2012. To further strengthen its stewardship role, the Government created a National Health Institute to support health surveillance, research and knowledge generation, and the National Directorate of Medicines (Dirección Nacional de Medicamentos).

However, the health sector should improve allocation and efficiency of budgeting and planning processes. To date, budgets and plans are still based on historical trends and not linked with results and evidence based decision making. In addition, a review of the increase in budgetary commitments and budgetary allocation in health should also confirm the sustainability of the newly implemented model of expanded primary health care.

\section{Performance and Challenges in Social Protection and Labor}

\section{V.1 Recent Evolution of Public Spending on Social Protection and Labor}

Overall social protection and labor (SPL) spending has increased in recent years, especially in social assistance and subsidies. The SPL system is composed of both contributory programs (e.g. pensions) and non-contributory benefits (social assistance, labor, subsidies). Overall SPL spending rose from 3.5 to 5 percent of GDP between 2007 and 2013 (Figure 45). Fiscal support for SPL also increased as a share of total public spending (15.6 percent in 2013, vs. 12.7 percent in 2007) (Figure 46), and benefits per capita grew in real terms during that same time period ( $\$ 328$ in 2013, vs. $\$ 243$ in 2007) (Figure 47). Notwithstanding these increased allocations, total SPL spending is on the lower range in regional terms, below Costa Rica, Honduras, and Panama in Central America, though higher than Nicaragua and Guatemala (Figure 48). The primary driver of the increase in SPL spending comes from expansion of non-contributory benefits, which rose from 1.6 percent of GDP (and \$110 per capita) in 2007 to 2.6 percent of GDP (and \$173 per capita by 2013). Utility subsidies claim the largest and fastest growing share of non-contributory benefits. In contrast, public spending on pensions has held steady over the past few years, with 2.4 percent of GDP allocated to complement private contributions for these benefits. 
El Salvador Social Expenditure and Institutional Review

Figure 45: Social protection and security as a $\%$ of GDP (\%)

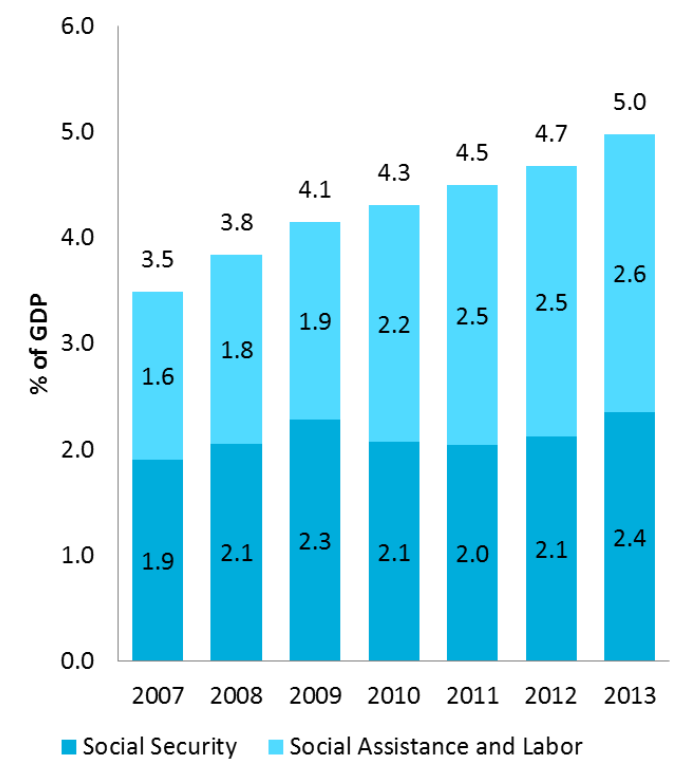

Source: World Bank SSEIR / ICEFI social spending database

Figure 47: Social protection and security Per-capita Public Spending (US\$2007)
Figure 46: Social protection and security as a $\%$ of Total Public Spending (\%)

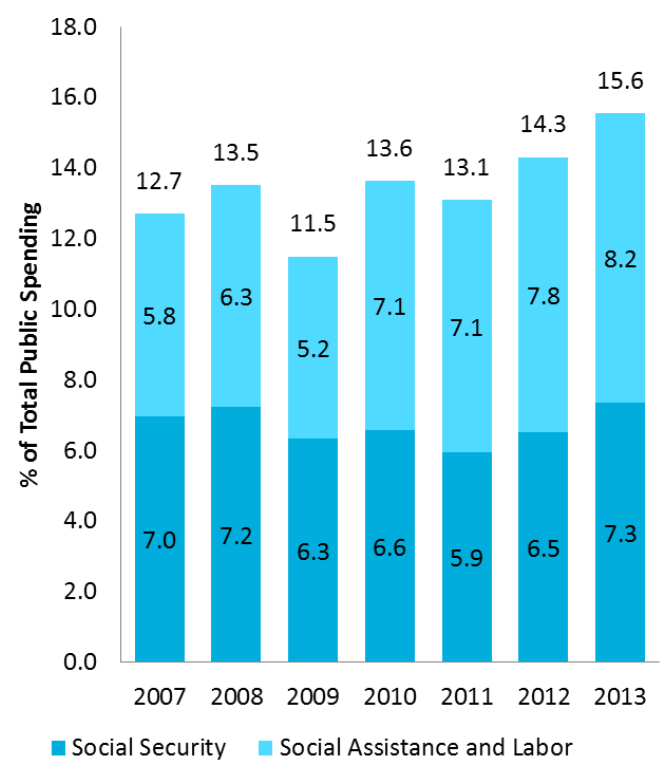

Source: World Bank SSEIR / ICEFI social spending database

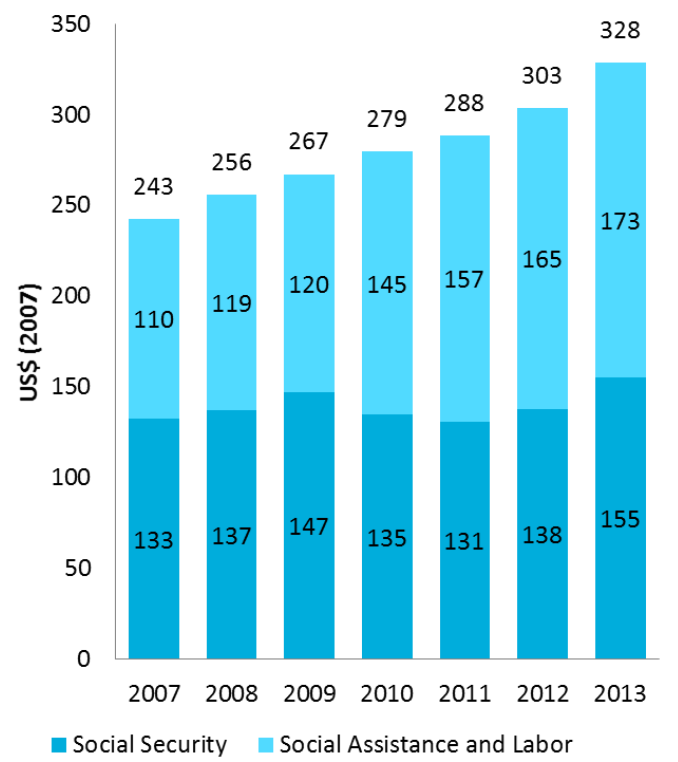

Source: World Bank SSEIR/ ICEFI social spending database 
Figure 48: Social protection and security as a $\%$ of GDP by country $2012(\%)$

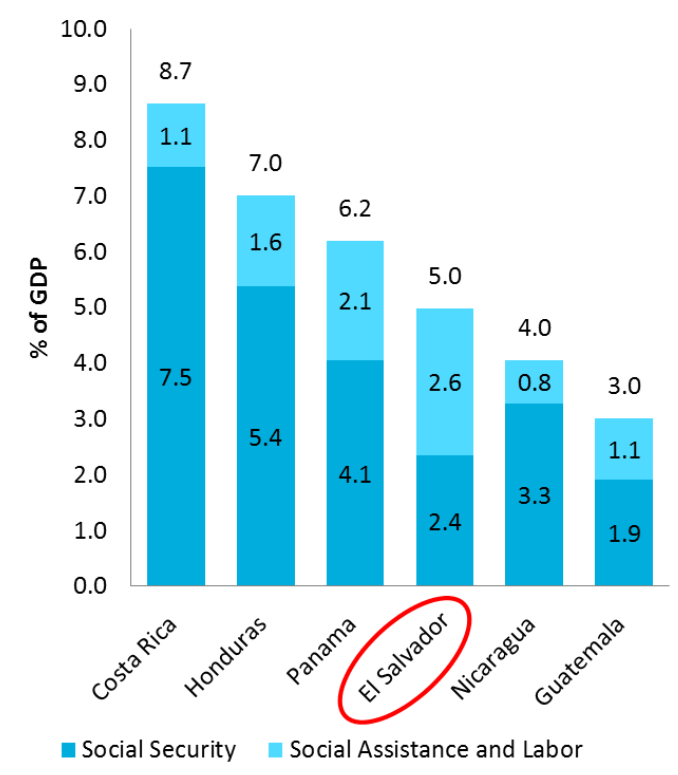

Source: World Bank SSEIR / ICEFI social spending database

Social security payments exacerbate the national fiscal deficit. In 1998, El Salvador shifted from a pay-as-you-go (PAYGO) pension system to a private funded "second pillar" scheme (Sistema de Ahorro para Pensiones, SAP) as follows: (i) women 50 and older men 55 and older remained in the old system (Sistema Público de Pensiones, SPP); (ii) individuals younger than 36 (and new entrants) were moved to the new system, (iii) while the group between both ages could choose which system to join. This shift in the pension system generated important "transition costs", given that most contributions moved over to the new private account system, but the Government had to continue paying its pension obligations for the PAYGO scheme: by the end 2011, 98.7 percent of contributors where contributing through the second-pillar SAP scheme. ${ }^{18}$ Moreover, due to low returns to investments of SAP, the Government has had to transfer resources to guarantee the minimum pension by law. In 2012, social security expenses from central government accounted for 2.4 percent of GDP. These public contributions to social security are projected to remain at high level for the near future, falling only to 1.8 percent of GDP by 2030 as transition costs diminish. ${ }^{19}$ Total unfunded fiscal liabilities of the pension system (comprising the public and private component) range from 65 to 75 percent of GDP in $2013 . .^{20}$

\footnotetext{
18 (Rofman, Apella, \& Vezza, 2015)"

${ }^{19}$ World Bank (2010b), "El Salvador Public Expenditure Review."

${ }^{20}$ IMF (2013), "El Salvador Article IV 2013.”
} 
Spending on non-contributory social assistance rose significantly in recent years, mainly due to an expansion of untargeted utility subsidies. The non-contributory components of El Salvador's SPL system include a wide range of social assistance benefits, labor market programs, and subsidies. Spending on non-contributory programs has increased sharply in recent years, rising by a full percentage point of GDP since 2007 (Figure 49), putting El Salvador among the higher spenders on non-contributory benefits in Central America. Untargeted utility subsidies absorb half of these outlays, now claiming 1.3 percent of GDP, the highest in Central America, and have been the primary driver of increases in outlays on overall SPL in recent years (Table 4). Besides subsidies, some 0.2 percent of GDP is absorbed by cash transfers, mainly the rural conditional cash transfer, (CCT, currently named "Comunidades Solidarias Rurales") and the Temporary Income Support program ("Programa de Apoyo Temporal al Ingreso", PATI) which operates in urban areas. The social pension and other programs for the elderly and the disabled account for an additional 0.4 percent of GDP. A range of other social assistance programs absorb another 065 percent of GDP, the most important being (a) Paquetes Escolares, which delivers free uniforms to primary students since 2009 and costs 0.3 percent of GDP; (b) Paquetes Agricolas, which distributes agricultural inputs ( 0.17 percent); and (c) school feeding (0.08 percent). Spending on active labor market programs is negligible (though donors operate on their own a wide number of pilots of low resource and coverage), the majority of them training courses managed by the public training agency, the Salvadoran National Institute for Professional Training (INSAFORP).

Figure 49: Social Assistance and Labor spending in E1 Salvador, 2007-2013

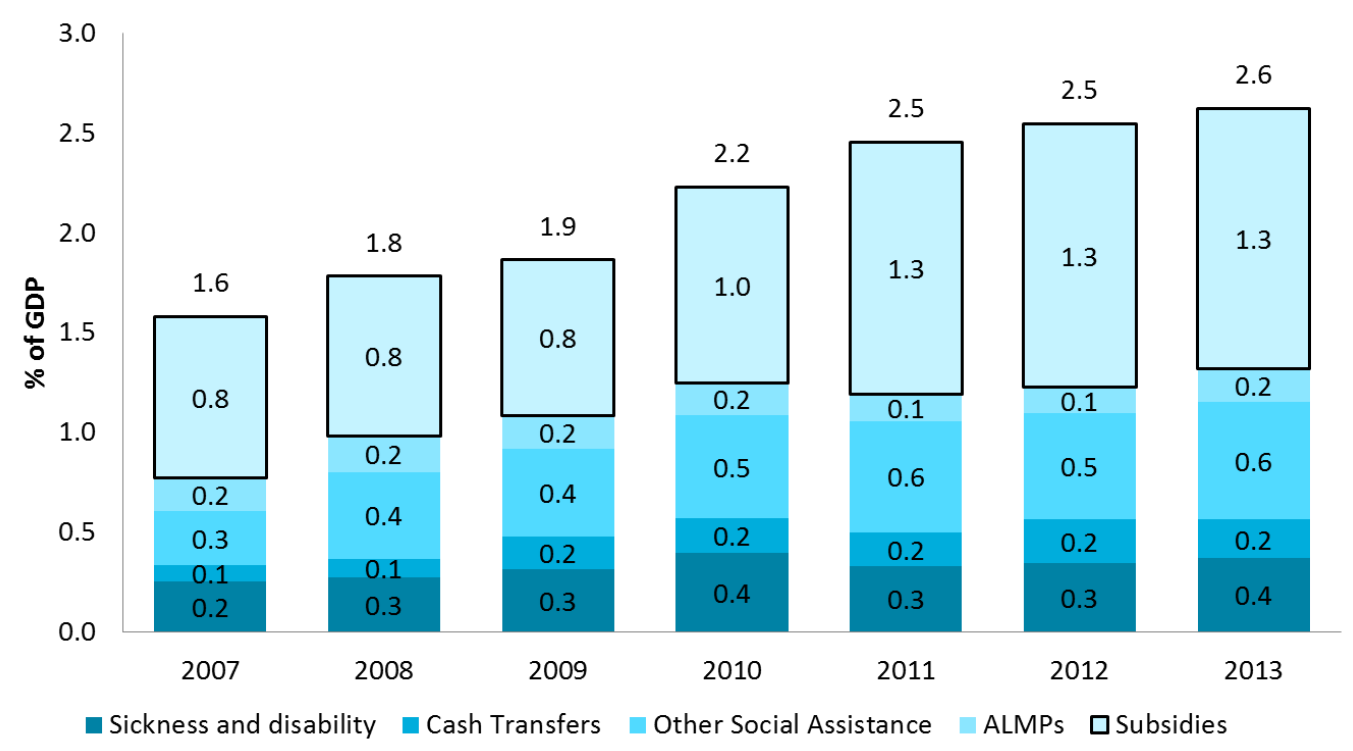

Source: World Bank SSEIR / ICEFI social spending database 
Table 4: Main Social Protection Programs in E1 Salvador

\begin{tabular}{|c|c|c|c|c|c|c|}
\hline Name of Program & Description & $\begin{array}{c}\text { Target } \\
\text { Population }\end{array}$ & $\begin{array}{l}\text { Coverage } \\
\text { per year } \\
\text { (persons) }\end{array}$ & 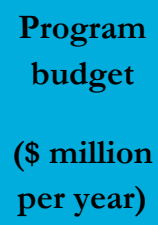 & 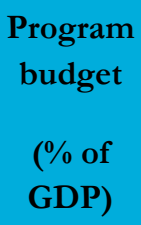 & $\begin{array}{c}\% \\
\text { Coverage of } \\
\text { Q1 }(\%)\end{array}$ \\
\hline $\begin{array}{c}\text { Subsidio } \\
\text { Electricidad }\end{array}$ & $\begin{array}{l}\text { Electricity } \\
\text { subsidy }\end{array}$ & Universal & $4,390,000$ & 175 & 0.73 & 61.3 \\
\hline $\begin{array}{l}\text { Subsidio Gas } \\
\text { Licuado }\end{array}$ & Gas subsidy & Universal & $4,250,000$ & 133 & 0.56 & 60.2 \\
\hline Paquetes Escolares & $\begin{array}{c}\text { School } \\
\text { textbooks and } \\
\text { uniforms }\end{array}$ & $\begin{array}{l}\text { Children in } \\
\text { basic } \\
\text { education }\end{array}$ & $1,386,767$ & 70 & 0.29 & 73.1 \\
\hline Paquetes Agrícolas & Food security & Rural areas & 536,137 & 40 & 0.17 & $\mathrm{~N} / \mathrm{A}$ \\
\hline $\begin{array}{c}\text { Comunidades } \\
\text { Solidarias Rurales }\end{array}$ & $\begin{array}{c}\text { Conditional cash } \\
\text { transfers }\end{array}$ & Rural families & 415,000 & 25 & 0.10 & 12.7 \\
\hline $\begin{array}{l}\text { Alimentación } \\
\text { Escolar }\end{array}$ & School feeding & $\begin{array}{l}\text { Children in } \\
\text { basic } \\
\text { education }\end{array}$ & $1,453,118$ & 20 & 0.08 & 72.6 \\
\hline PATI & $\begin{array}{l}\text { Income support } \\
\text { for unemployed }\end{array}$ & $\begin{array}{c}\text { Urban } \\
\text { unemployed }\end{array}$ & 23,456 & 12 & 0.05 & 1 \\
\hline $\begin{array}{c}\text { Pensión Básica } \\
\text { Universal }\end{array}$ & Social Pension & $\begin{array}{l}\text { Elderly rural } \\
\text { areas }\end{array}$ & 28,200 & 11 & 0.05 & 2 \\
\hline Ciudad Mujer & $\begin{array}{l}\text { Integral care for } \\
\text { women }\end{array}$ & Adult women & 315,000 & 10 & 0.04 & $\mathrm{~N} / \mathrm{A}$ \\
\hline
\end{tabular}

Source: Administrative data from LAC SP database based on Technical Secretariat of the Presidency. Coverage \%Q1 from World Bank SSEIR team's analysis of household surveys, authors' calculations using standardized ADePT software (Social Protection Module)

\section{V.2 Results and Outcomes}

Overall, the performance of El Salvador's Social Protection and Labor programs is mixed, and spending allocations do not favor the better performing programs. Indeed, pension coverage has not improved much despite system reforms and the introduction of the Social Pension. And programs such as the rural CCT and the Urban PATI programs demonstrate positive impacts, but remain relatively small due to low funding. In contrast, utility subsidies receive a high share of SPL outlays, despite the fact that they are quite regressive. 
Despite the reforms, contributory pension coverage has not improved much: barely 20 percent of the elderly accrue a pension, just above Honduras and Nicaragua in coverage in the region (Figure 50). Contributions to the pension system (mostly SAP) are made by only 30.2 percent of the labor force, compared with 61 percent in Panama and 49 percent in Costa Rica. To increase coverage among the poor, the Government has recently launched a non-contributory Social Pension program called Pension Basica Universal, targeted to poor elderly (more than 70 years old) as a complement of the rural CCT program (Comunidades Solidarias Rurales). The social pension now reaches 30,000 individuals living in the 75 poorest rural municipalities, and its budget represents 0.05 percent of GDP. Participants receive a pension transfer of US $\$ 50$ per month, provided they do not get any other pensions. The Government plan is to reach 50,000 individuals in 100 rural municipalities in 2014, as well as expand in urban areas as well provided resources are available. Population estimates suggest that 130.000 poor elderly would qualify for this pension if coverage is extended nationally, which will require at current benefit levels a budget several times its current size, to reach approximately 0.33 percent of GDP. ${ }^{21}$

Figure 50: Coverage of social security 2007-2013

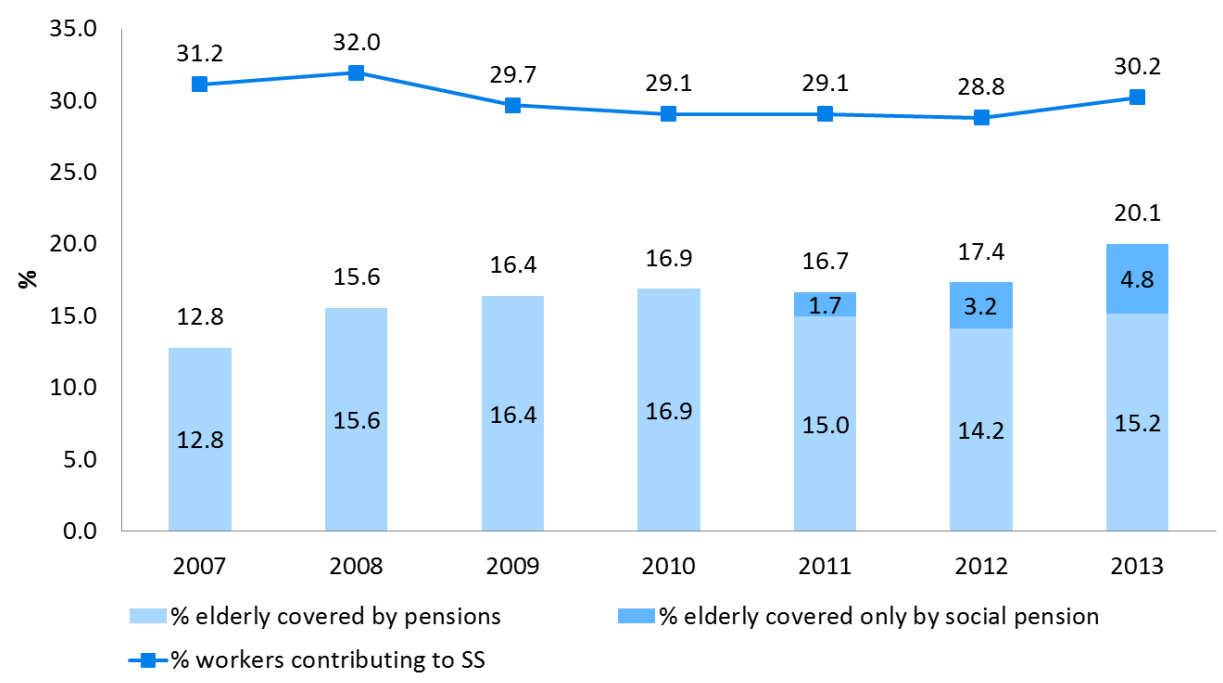

Source: World Bank SSEIR team's analysis of household surveys, authors' calculations using standardized ADePT software (Social Protection Module)

The Rural CCT program is well targeted with important impacts, despite low coverage and declining funding. In face of high income poverty in rural areas, the Government of El Salvador introduced a conditional cash transfer (CCT) program named Red Solidaria in 2006, which was later renamed Comunidades Solidarias Rurales in 2009. This program provides income grants of $\$ 30$ a month

21 (Rofman, Apella, \& Vezza, 2015). 


\section{El Salvador Social Expenditure and Institutional Review}

to rural mothers if their children comply with school attendance (at primary level) and regular health visits in 100 rural municipalities (out of a total of 262 in the country). ${ }^{22}$ El Salvador's CCT has been relatively well targeted, as compared with other CCT programs in the region. However, the amount spent as a share of GDP is the lowest in the CA region (Figure 51). ${ }^{23}$ A recent impact evaluation in targeted municipalities has shown important impacts, including: (a) increasing primary school enrollment by eight percentage points to reach 98 percent in 2009; (b) reducing repetition rates by eight percentage points; and (c) reducing the prevalence of diarrhea by 4 percentage points. ${ }^{24}$ However, the budget and coverage of the CCT program have declined in recent years, from about $\$ 40$ million per year and 106,000 households in 2010 (6.7 percent of all households in the country, 19.3 percent among those in the lower quintile) to $\$ 25$ million and 90,000 households by 2013 (4.9 percent of total households, 12.7 percent among those in the poorest quintile). This decline in coverage has occurred because families that exit the program because of program rules have not been replaced by new eligible families, and the program did not expand to new areas (despite plans to expand to urban areas, currently at just 5 municipalities). As a result, El Salvador's CCT has the lowest coverage among CCTs in the CA region, 4.9 percent of total households (2013) compared to Guatemala 30 percent (2011), Costa Rica 12.7 (2013), Honduras 10 percent (2013) and Panama 10 percent $(2013)^{25}$.

\footnotetext{
22 The Rural CCT also has a component to improve supply of basic services (water and sanitation, electrification, housing), as well as income generation and productive development (microcredit, food security, labor-intensive community projects), though the latter has not operated effectively.

${ }^{23}$ FUSADES and IFPRI (2010). "Evaluacion Externa del Programa Red Solidaria: Informe de Impactos a los Dos Años de Implementacion."

${ }^{24}$ FUSADES and IFPRI (2010).

25 World Bank SSEIR team's analysis of household surveys, authors' calculations using standardized ADePT software (Social Protection Module)
} 
Figure 51: Coverage and Budget of CCT Programs in Latin America

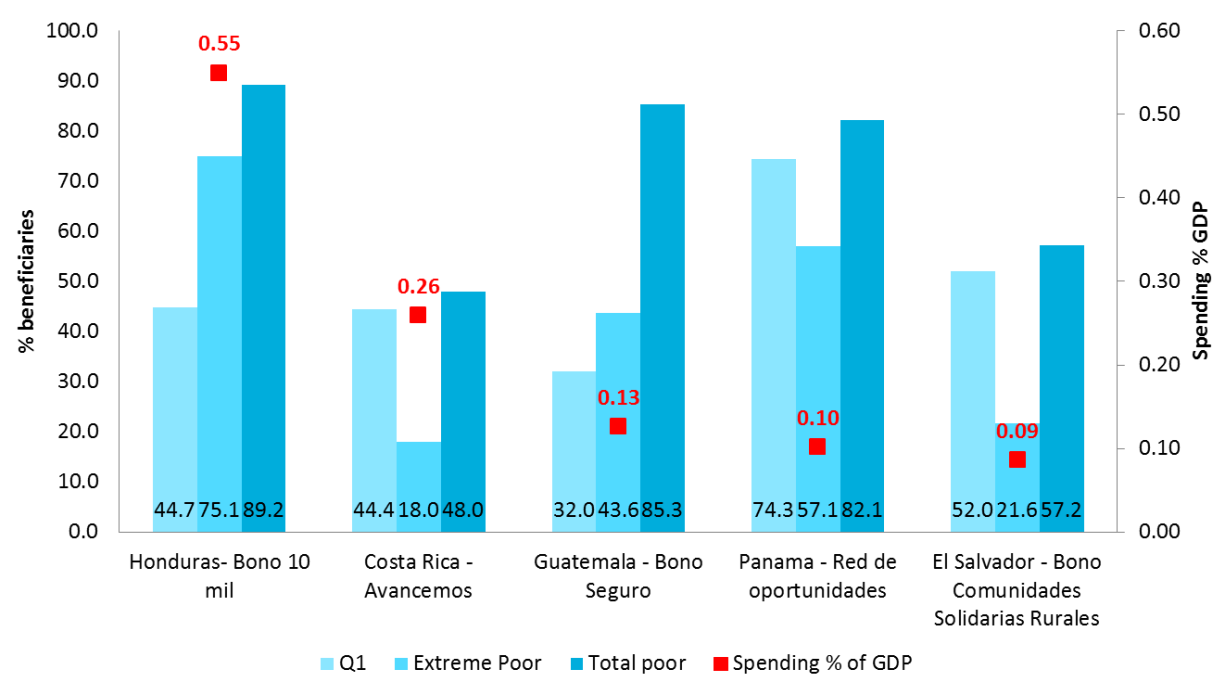

Source: For beneficiaries: World Bank SSEIR team's analysis of household surveys, authors' calculations using standardized ADePT software (Social Protection Module). For spending: LAC SP database

In urban areas, the main intervention is a workfare program that combines income support with training, with important impacts. Within Comunidades Solidarias strategy, PATI is the core social protection intervention in urban areas, having benefiting up to date about 63,000 participants in urban poor settlements in 36 municipalities, with demonstrated impact. The PATI program initially started as response to the economic crisis affecting the country in 2009. It is aimed at mitigating poverty and improving productive capacities and enhanced opportunities for employment of women heads of household and youngsters. To achieve these goals, PATI provides a cash benefit of $\$ 100$ per month for a maximum of six months, conditional on participation in community projects, occupational training, and labor market orientation courses. The expectation is that by end of the six month period, the beneficiaries can enter the labor market and/or create their own productive income generation activities to avoid being stuck in the vicious circle of poverty. The lead implementing institution is FISDL, in coordination with municipalities that formulate and monitor projects, the Ministry of Labor (MTPS) which provides labor market orientation, and INSAFORP, the national training institute, in charge of providing occupational training in areas selected according with local labor demand and participant profiles. The PATI program has already demonstrated impact per a rigorous evaluation including: reducing extreme poverty among beneficiaries, increasing labor force participation and labor incomes (in particular among the youth), and improving readiness to start a new job (Figure 52). ${ }^{26}$

Figure 52: Impact of PATI on labor force participation and incomes.

\footnotetext{
${ }^{26}$ Beneke de Sanfeliu and Acosta (2014), "Programa de Apoyo Temporal al Ingreso (PATI): Evaluación de Impacto.”
} 
El Salvador Social Expenditure and Institutional Review

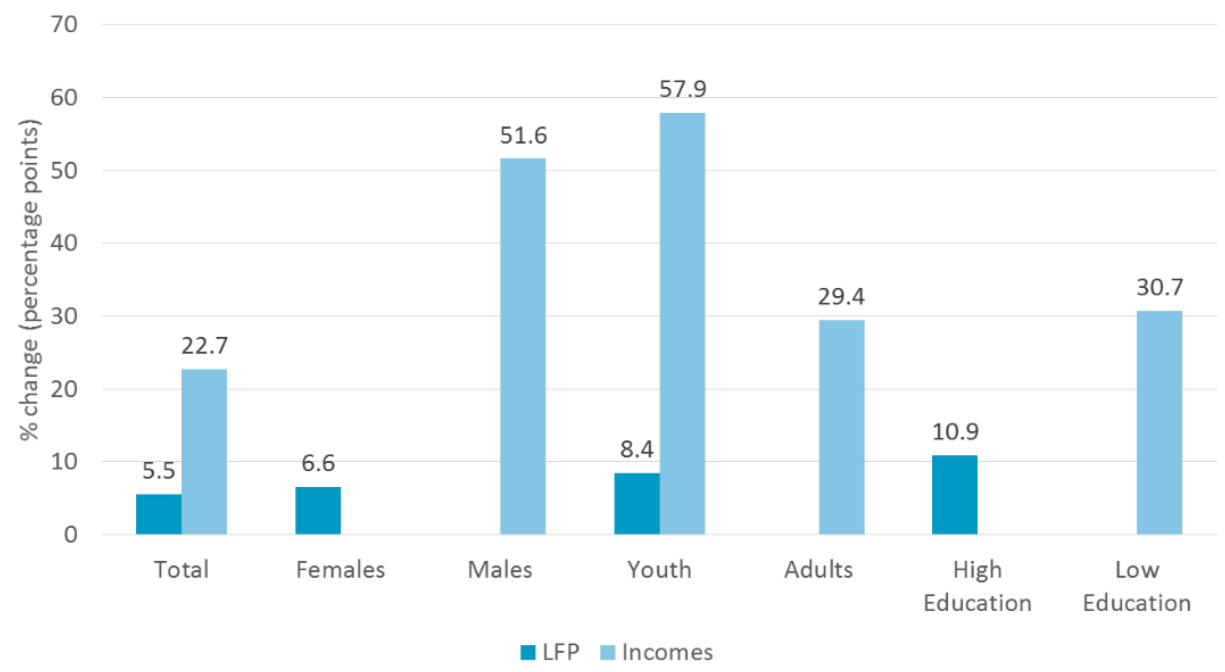

Source: Beneke de Sanfeliu and Acosta (2014).Note: Impact corresponds to one year after program participation.

Nationally, the Government of El Salvador also operates an untargeted "school inputs" program to incentivize school attendance: without an impact evaluation, the results of this program are still unknown. In contrast to the cuts in coverage and funding for the targeted rural CCT program, the Government (last administration) has been prioritizing the Paquetes Escolares Program, which combines provision of free school uniforms to all students attending public education, with the goal of incentivizing school attendance and retention. Uniforms are produced locally, and thus attending a second objective which is the creation of employment opportunities. This program started in 2009 and has expanded rapidly in subsequent years, currently covering about 1.36 million students. The Paquetes Escolares Program is much larger than the CCT or PATI, with good coverage of the poor 73 percent of families in the poorest quintile receiving the Paquete Escolar benefit (

Figure 53), as compared with 12.7 percent for the Rural CCT and only 1 percent for PATI (Table 4). Given that the Paquetes Escolares Program also adopts a universal approach as opposed to the targeted CCT and PATI programs, it is not surprising that some well-off families also receive the Paquetes Escolares benefits (23.7 percent of families in the richest quintile receive the Paquetes benefits). As rigorous impact evaluations have not been carried out, there is no evidence as to whether this program is indeed helping to retain children at school as expected, and whether is costeffective. 
Figure 53: Coverage of Paquetes Escolares, 2013.

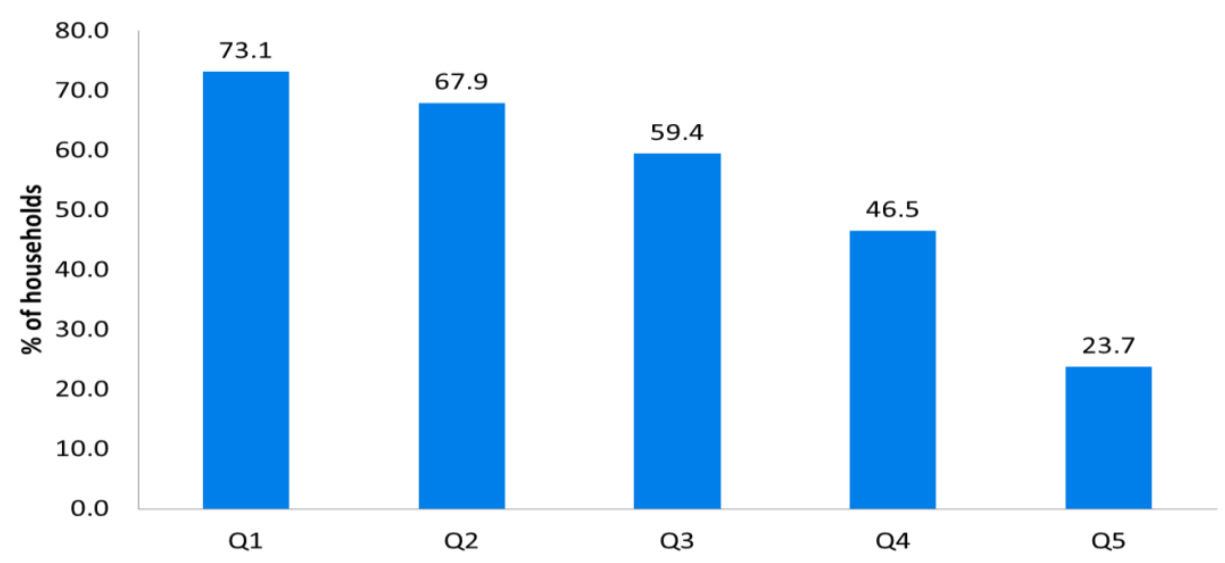

Source: World Bank SSEIR team's analysis of household surveys, authors' calculations using standardized ADePT software (Social Protection Module)

Electricity and gas subsidies account for half of non-contributory spending, twice as much any other Central America country, and have grown over time despite attempted failed reforms. Electricity and gas subsidies accounted in 2013 for 0.7 and 0.6 percent of GDP respectively (Figure 54). In this sense, El Salvador is an outlier in the region, since the second country that spends the most on subsidies in Central America is Panama, at 0.7 percent of GDP. Particularly worrisome is the case of electricity subsidies, more than doubling from a relatively low base of 0.3 percent of GDP in 2007. For the case of gas (liquefied petroleum gas, LPG), while still at high levels, it has remained relatively stable across the years at 0.5-0.6 percent of GDP. The increase in electricity subsidy obeys to the fact that in 2010 of the consumption range between 100 and 200 $\mathrm{kWh}$ also started to become subsidized. For the case of LPG, a reform took place in April 2011 aimed at containing subsidies, through the removal of the price subsidy resulting in a price increase for consumers per bottle, the most common fuel used for cooking by Salvadorans at home. ${ }^{27}$, In place of the price subsidy the authorities introduced a monthly transfer of $\$ 8.50$ to households with an electricity consumption of less than $200 \mathrm{Kwh}$ per month, provided through the monthly electricity bill. This was a relatively high cut-off as around 94 percent of households with access to electricity consumed less than the eligibility threshold, which explains why the LPG subsidy bill did not decline thereafter. Moreover, households without access to electricity were also entitled to a government-issued card that would allow them to collect the monthly LPG $\$ 8.50$ subsidy, which marginally helped to improve its targeting.

${ }^{27}$ Calvo-Gonzalez, Cunha, Trezzi (2014), "When winners feel like losers”. 
Figure 54: Spending in Electricity and gas (LPG) subsidies, E1 Salvador, 2007-2013.

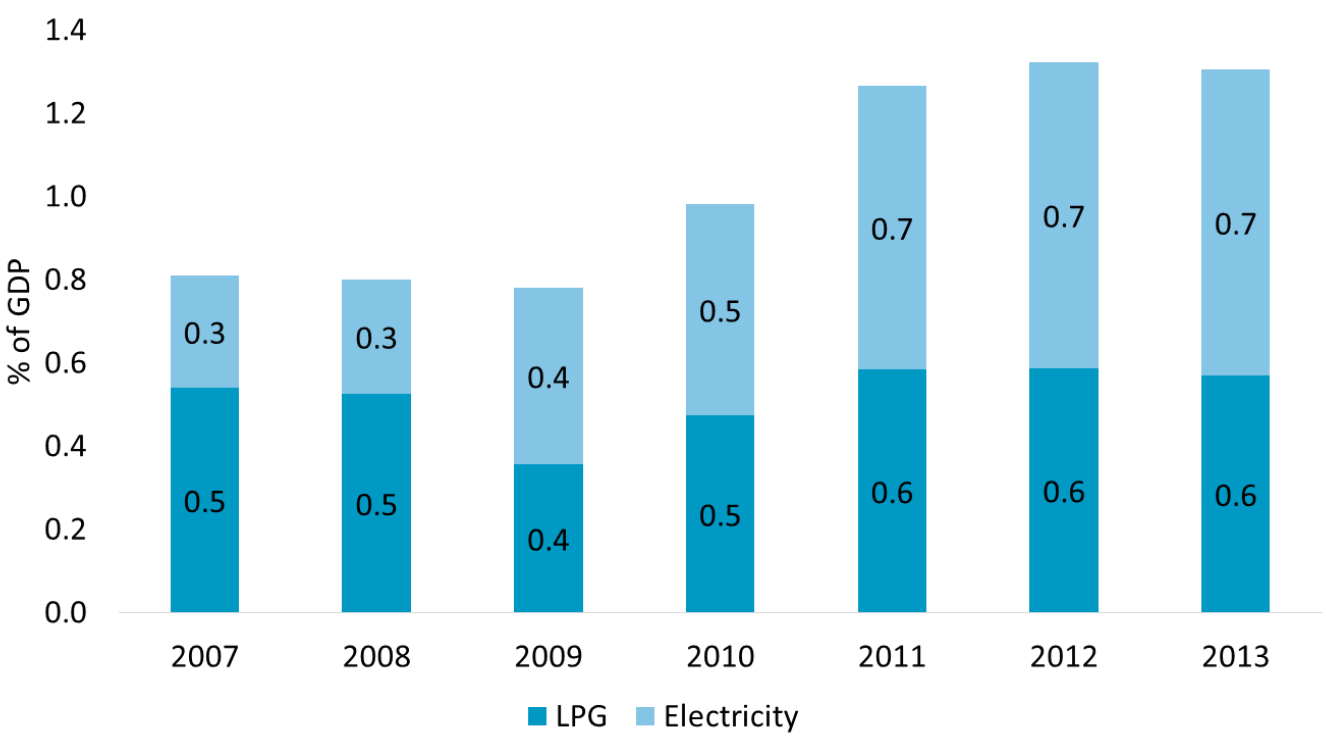

Source: World Bank SSEIR / ICEFI social spending database

Across programs, a large share of overall social assistance spending goes to "leakages" to non-poor families, to the detriment of targeted programs. Looking across programs, the cost effectiveness and impact of social assistance on poverty are compromised by biases in spending on untargeted benefits, with relatively little funding for the targeted programs. As expected, most beneficiaries of the CCT, Social Pension and PATI are poor (Figure 55). "Leakages" to the nonpoor of these interventions are very small, in line with most mature transfer programs in the region. However, this is not the case for other social assistance programs that have universal focus, such as school feeding, Paquetes Escolares, and the gas, electricity and water subsidies. In terms of coverage of main social programs, the inequities are sticking: while the well-targeted CCT program covers barely 12.7 percent of extreme poor families, nearly 68.3 percent of the richest families receive Government subsidies (Figure 56). This is not surprising given that, for instance for the case of LPG, two-third of families in the lowest income decile do not cook using LGP. ${ }^{28}$

${ }^{28}$ Artana and Navajas (2008), “Analisis y rediseno de los subsidios en El Salvador”. 
El Salvador Social Expenditure and Institutional Review

Figure 55: Beneficiary incidence of major social protection programs in E1 Salvador, 2013

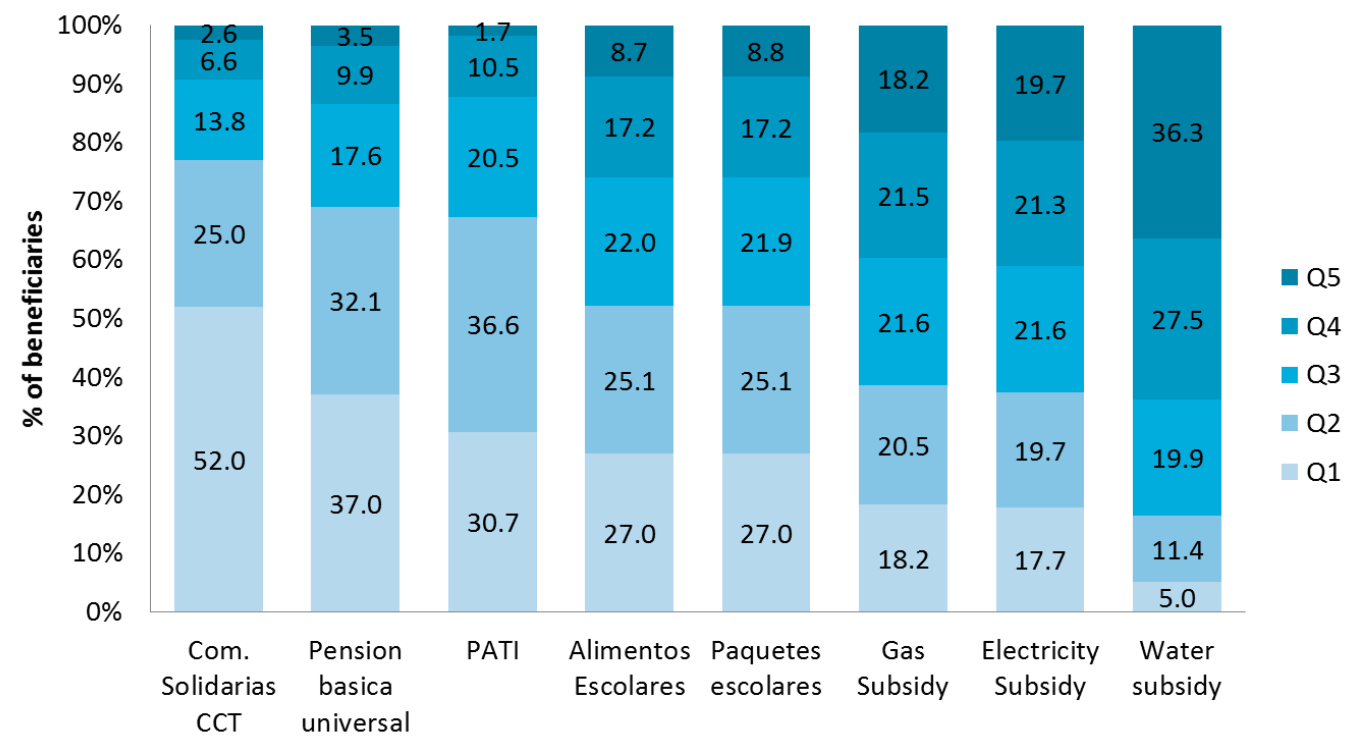

Source: World Bank SSEIR team's analysis of household surveys, authors' calculations using standardized ADePT software (Social Protection Module)

Note: Beneficiary incidence is defined as the number of individuals in the group who live in a household where at least one member receives the transfer, in proportion of the total number of direct and indirect beneficiaries.

Figure 56: Coverage of CCT and energy subsidies by income quintile, El Salvador 2013

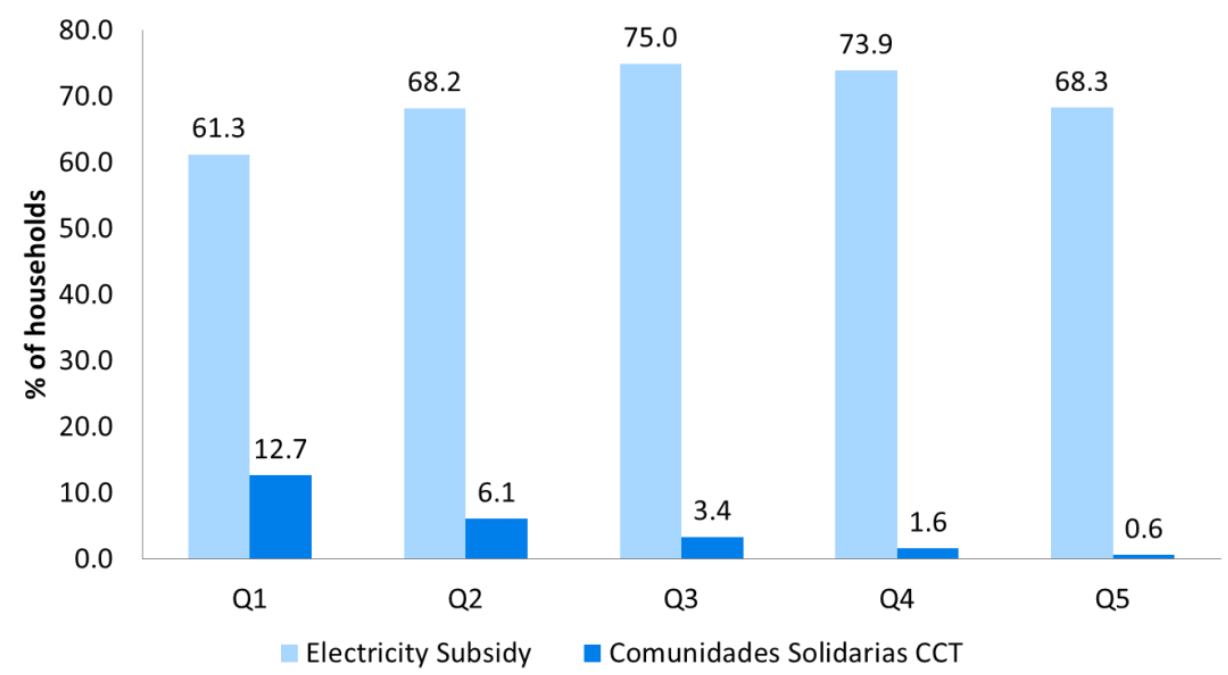

Source: World Bank SSEIR team's analysis of household surveys, authors' calculations using standardized ADePT software (Social Protection Module) 
El Salvador could save at least 0.66 percent of GDP ( $\$ 160$ million) in subsidies that accrue to the top two quintiles. The fact that a significant portion of resources in social assistance and subsidies are not reaching the poor could be an explanation of why poverty has not declined much in El Salvador despite the expansion in fiscal resources devoted to social protection. Taking into account current levels of spending on the various programs, and the distribution of beneficiaries per income quintile, El Salvador could save at least 0.66 percent of GDP in subsidies and other social assistance program benefits to the top two richest quintiles (Figure 57). Moreover, subsidy amounts tend to be higher for the rich than for the poor. Recent analyses provide evidence that subsidy reform could start with a sequenced and gradual approach. ${ }^{29}$ For instance, excluding households with consumption between 100 and $200 \mathrm{kWh}$ of electricity from both the electricity and LGP subsidy system would reduce the average amount received per month by richer households (top two quintiles) by both concepts from $\$ 16.5$ to $\$ 9.7$. Annual savings from this measure would be approximately $\$ 122$ million or 0.45 percent of GDP. These potential savings could be reallocate to better targeted programs, or to other sectors (such as Education, which remains under-funded) - or they could be used to help plug the fiscal deficit.

Figure 57: Distribution of Benefits of Major Social Assistance Programs (\% of GDP)

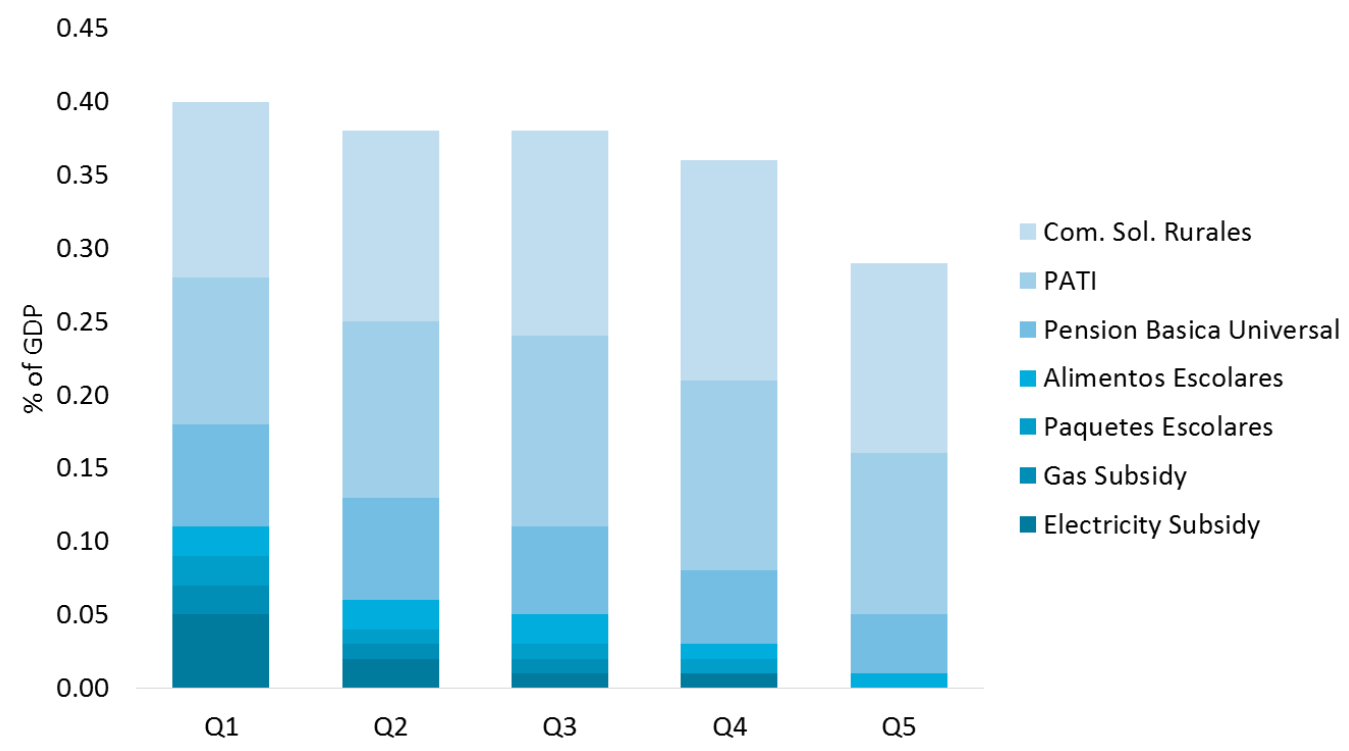

Source: World Bank SSEIR team's analysis of household surveys, authors' calculations using standardized ADePT software (Social Protection Module)

Income vulnerabilities are also reflected in persistent employability challenges for a large majority of the population, with difficulties in retaining a formal job. Half of the Salvadoran population is less than 30 years old. Every year, about 30,000 young Salvadorans enter the labor market for the first time and encounter scarce opportunities. Around 55 percent of these new labor market entrants have less than secondary education, and 15 percent of them cannot find a job at all,

${ }^{29}$ World Bank (2014), “El Salvador: Fiscal Policy Options.” 
while 80 percent of those who manage to work end up in informal low-productivity activities. ${ }^{30}$ As stated before, just one in five workers contribute to the social security system or are employed in a medium-large firm. In fact, many youngsters enter into salaried jobs but as they age most are not able (or not willing, depending on the interpretation) to retain this status and transition into selfemployment activities by adulthood (Figure 58).

Figure 58: Type of Employment by Age Group, E1 Salvador 2013.

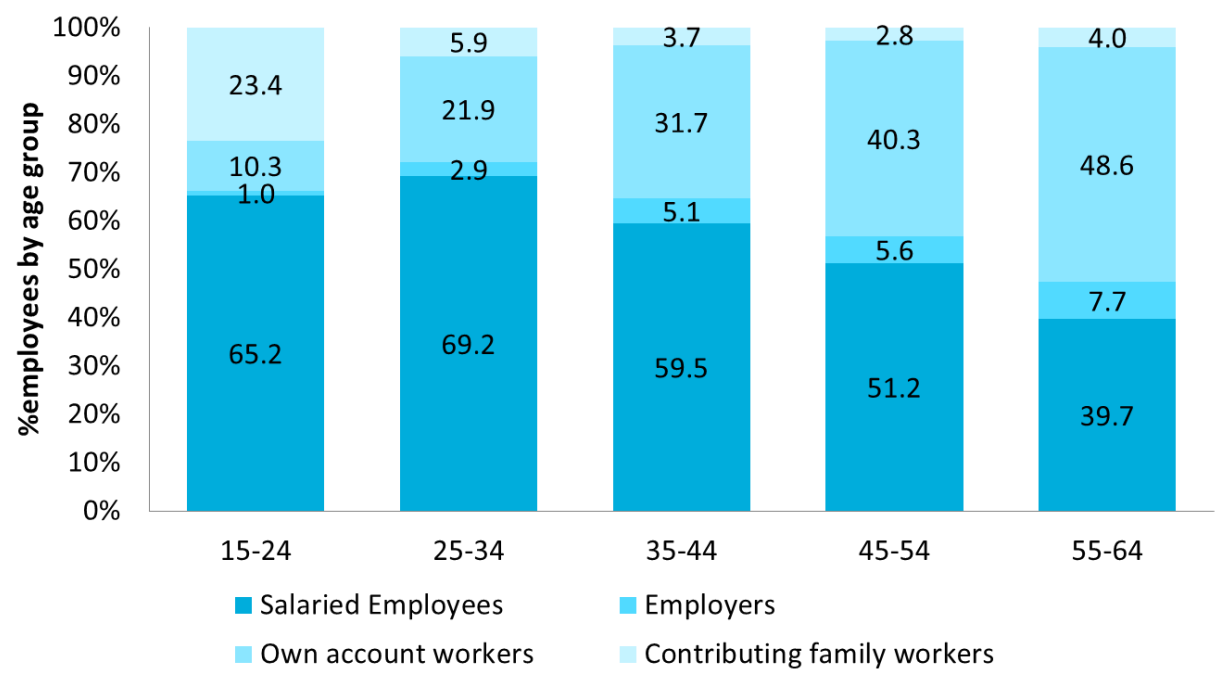

Source: World Bank SSEIR team's analysis of household surveys, authors' calculations using standardized ADePT software (Labor Module)

In recent years, unemployment has become a worrying reality for youngsters living in urban areas, even more for those with some secondary or tertiary education. In general, unemployment is in single digits in El Salvador, a similar fact than in many other Central American countries. However, in El Salvador the international financial crisis that took place in 2009 severely hit the country, especially in terms of employment. Unemployment rates almost doubled that year compared with levels up to date, and though it has later declined, it is still at much higher levels than pre-crisis period. In particular, the crisis hit harder in urban areas, and also among the youth, which still are almost three times more likely to fall into unemployment than adults (Figure 59 and Figure 60). Worryingly, most of the recent increase in unemployment affects the most those with relatively high levels of education, such as those with secondary education complete or incomplete tertiary education (Figure 61).

\footnotetext{
30 World Bank (2010a), "Mas y Mejores Empleos en El Salvador.”
} 
Figure 59: Unemployment rates by age group, E1 Salvador 2007-2013

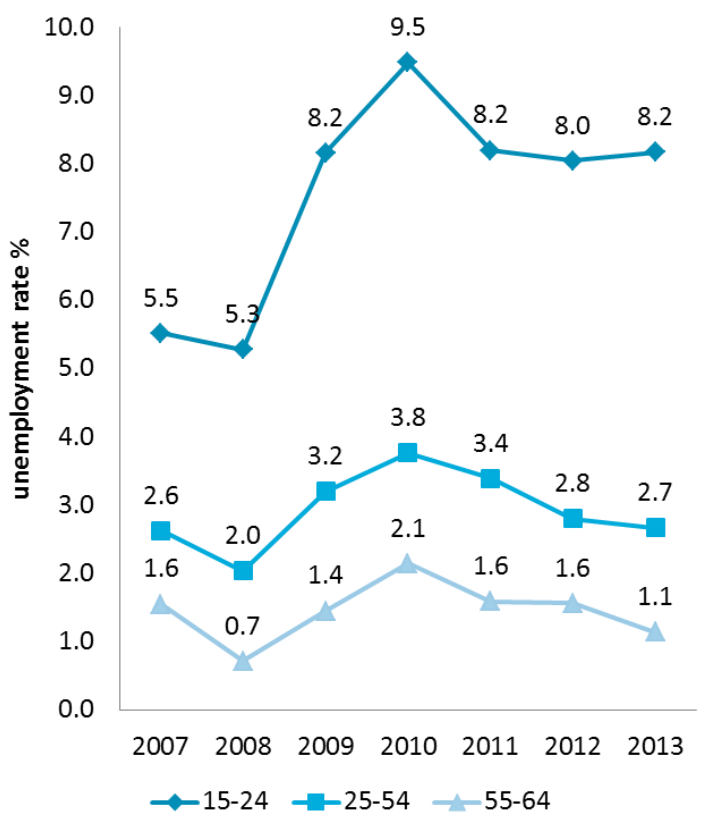

Source: World Bank SSEIR team's analysis of household surveys, authors' calculations using standardized ADePT software (Labor Module)

\section{Figure 60: Unemployment rates by area of residence, E1 Salvador 2007-2013}

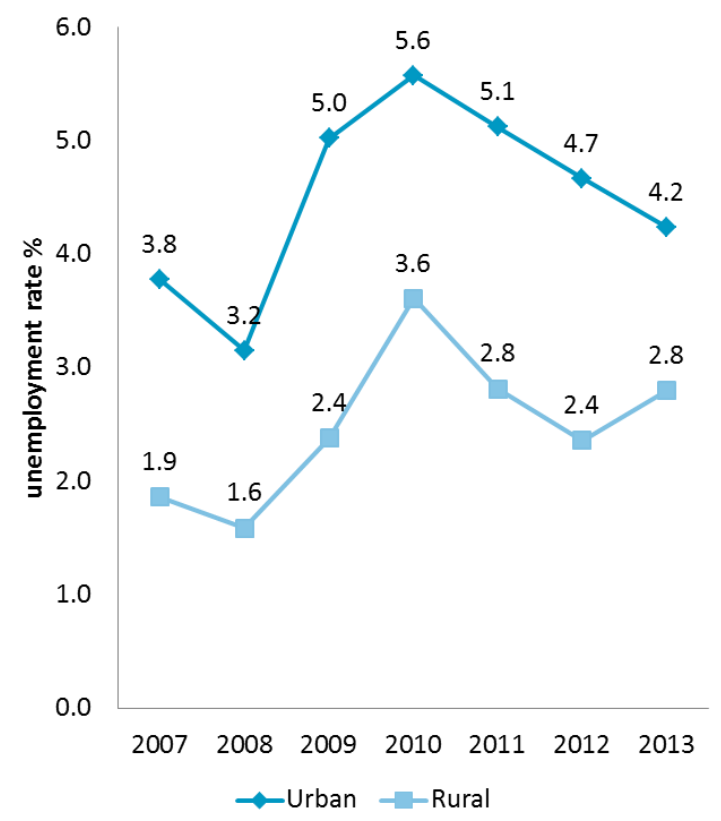

Source: World Bank SSEIR team's analysis of household surveys, authors' calculations using standardized ADePT software (Labor Module)

Figure 61: Unemployment rate, by education, E1 Salvador 2007-2013

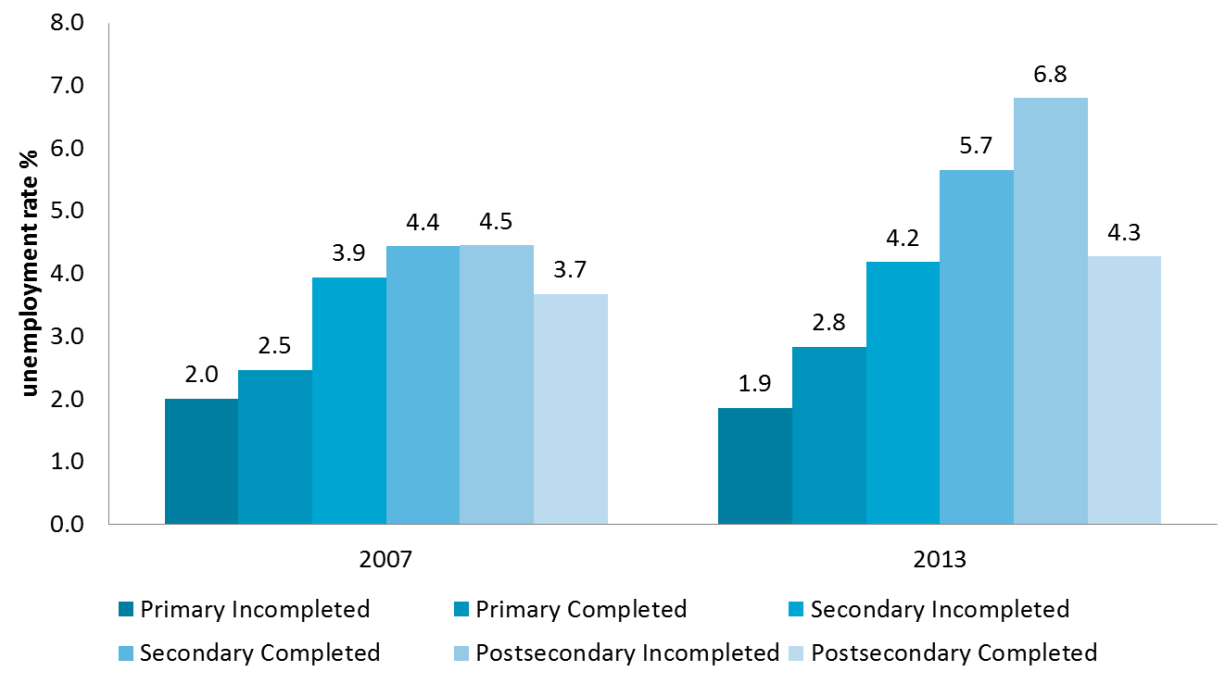

Source: World Bank SSEIR team's analysis of household surveys, authors' calculations using standardized ADePT software (Labor Module) 
While El Salvador has successfully reduced inequality in recent years, this is mainly due to patterns of labor earnings rather than redistribution via SPL transfers. As mentioned in the introduction, while poverty has not declined significantly in the last decade, inequality has fallen, with the Gini coefficient dropping from 0.485 in 2007 to 0.452 in 2013 . Given that social protection spending expanded but not as progressive at it could have been, benefiting still many better off families, the main candidate for explaining the fall in income inequality is the labor market. Indeed, the evidence shows that in this period, there has been an increase in labor incomes for the poorest and less educated workers, by about 15-20 percent in the last six years, while it has declined for workers with higher education (Figure 62). This evidence is also consistent with previous research, which signaled that labor market returns to education have declined in the 2000s, as opposed to the 1990s when they increased. ${ }^{31}$ If this is true, the positive news of the decline in inequality could be less so if it reduces the incentive to invest in education, with consequences for future growth prospects and competitiveness.

Figure 62: Change in Labor Incomes by Educational Level, 2007-2013

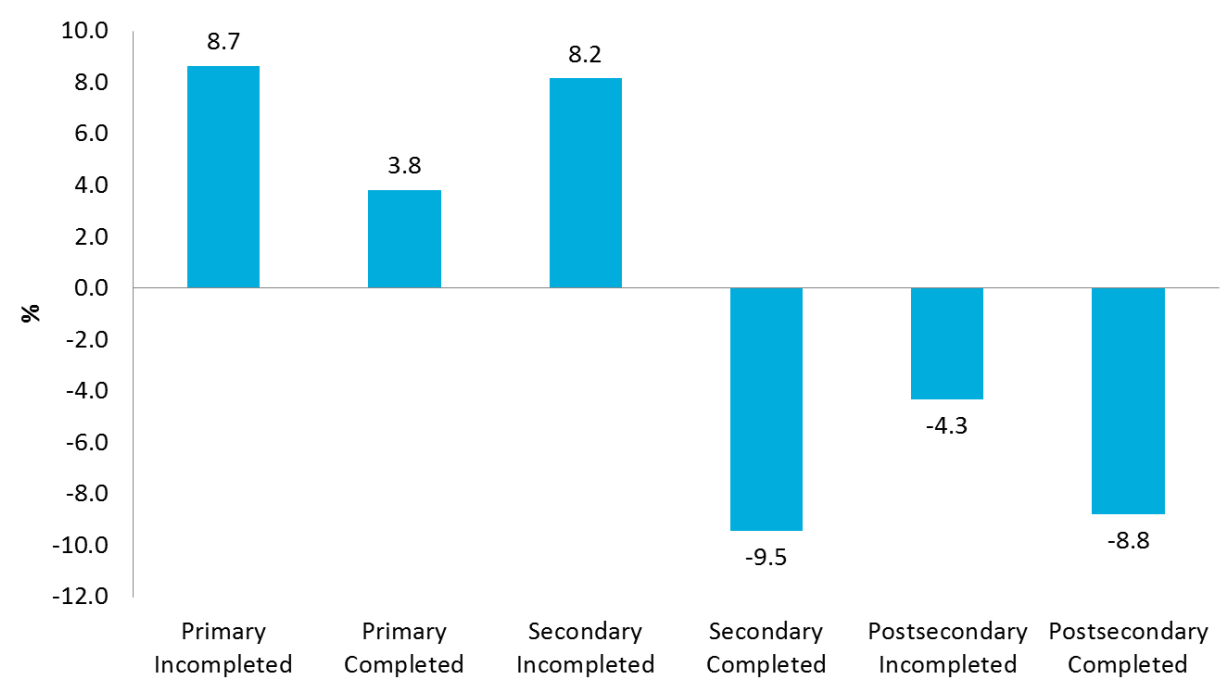

Source: World Bank SSEIR team's analysis of household surveys, authors' calculations using standardized ADePT software (Labor Module)

Evidence points out that the skills provided by the formal education sector may not be those necessarily demanded by the productive sector, and also a reflection of low educational quality. As described before, low educational quality is a concern in El Salvador, and can as such explain the recent trends in unemployment and remunerations for higher educated workers. But also could reflect a situation of "skills mismatch", if workers are trained in degrees that are not the most demanded in the labor market. Evidence shows that as in many other countries in the region, many Salvadoran firms are not satisfied with the skills the workers bring to the labor market: 37 percent of

31 (Gasparini, Galiani, Cruces, \& Acosta, 2011). 
them signals "lack of appropriate skills" as a major constraint to firm growth, a ratio that increases to 57 percent for firms in technology (IT) sectors (Figure 63).

Figure 63: Firms that Signals "Lack of Appropriate Skills" as the Major Constraint to Growth

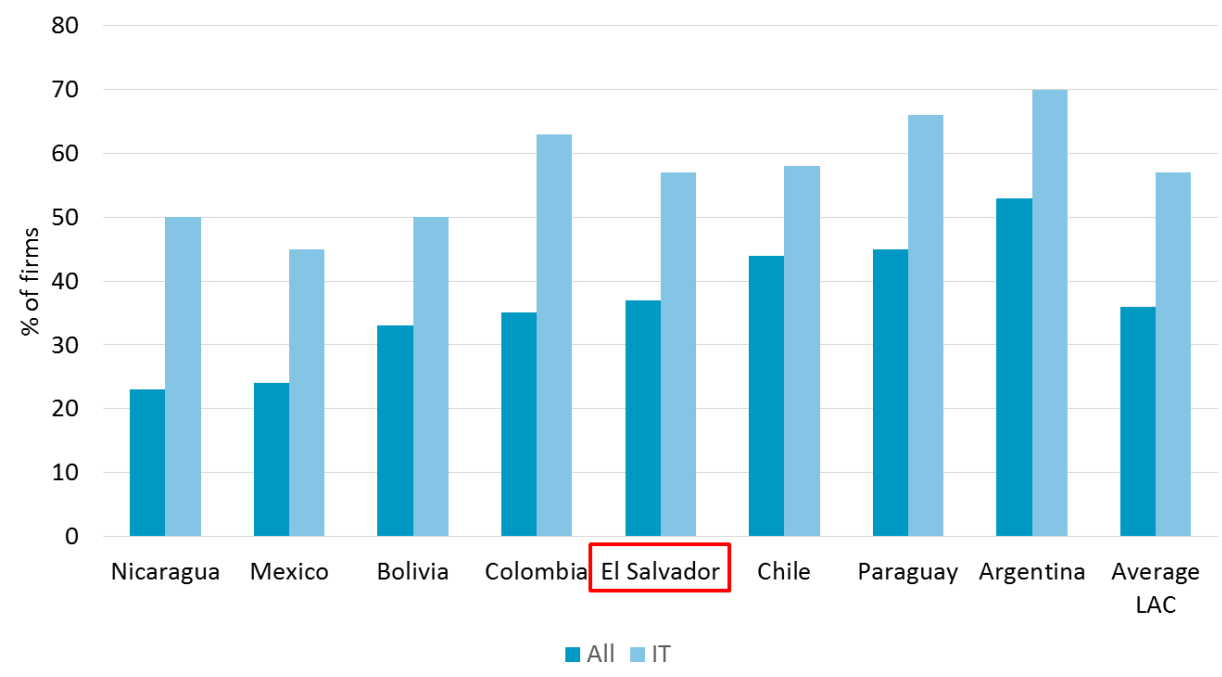

Source: World Bank Enterprise Surveys

Despite challenges in job creation, coverage of active labor market programs in El Salvador is low and not well targeted to priority groups. As noted above, spending on active labor market programs (ALMPs) in El Salvador accounts for just 0.1 percent of GDP (excluding PATI, which is classified as "income support social assistance"). The majority of these resources are managed by INSAFORP, which provides training to employed and unemployed population. While El Salvador does have some other programs that focus on facilitating employment creation, most of them are quite recent, with low coverage, and financed by donors as pilots outside Government budget. Still, the experience in the design and implementation of some of these interventions constitute a starting point to develop full scale actions reoriented mostly to the vulnerable segments of the Salvadoran population.

On labor intermediation, E1 Salvador currently has a system of employment services (which provides information on job vacancies. The rationale for job search and intermediation programs is that labor markets show incomplete information about existing job opportunities and the specific skills demanded in the market. Less educated individuals usually face serious information constraints when looking for a job, and they do not generally access to counseling and job search assistance programs. In El Salvador, the Government has implemented the Red Nacional de Empleo (RENACEMPLEO), a labor intermediation strategy administered by the Ministry of Labor (MTPS) in coordination with municipalities and NGOs. The system is implemented across the country in eight MTPS regional offices, and 35 additional employment offices. Each regional and employment 
offices collect information on job openings and posts job opportunities online for job seekers to apply, matching labor demand needs from the private sector with a registry of unemployed population. The RNE constitutes the entry point for interested unemployed participants who want to seek labor intermediation services from MTPS. Some regional offices also offer participants short motivational and advisory talks to help them in their job search process, more recently also to beneficiaries of PATI and participants in Ciudad Mujer, an integrated platform to connect services for women. The regular interventions in the job matching process are complemented by several employment fairs organized each year by MTPS. About 37,000 individuals each year are registered in RENACEMPLEO (the majority women and those with less than secondary education), as well as 700 employers, and up to 2009 (latest information available), about 30 percent of registered individuals found a job, most of them with a bachelor or other tertiary degree, and in manufacturing, public administration, hotels, restaurants, or other retail jobs. ${ }^{32}$

The labor intermediation system is seriously unfunded, and needs strengthening to meet its goals. The Government aims to expand the geographical coverage of RENACEMPLEO to reach a total of 66 municipalities, as well as improve the quality of the program by: a) training personnel to increase their adequacy and effectiveness in delivering services to the population from vulnerable settlements; b) establishing coordination mechanisms with municipalities through local social promoters that would help identify employment opportunities through a more effective interaction with the labor needs of local enterprises and municipalities; c) supporting a coordination mechanism with training institutions; and d) strengthening the monitoring system, analysis, and evaluation of the RENACEMPLEO, through a set of indicators that would systematically assess the results and impact. The current institutional arrangements of the RNE also appear to have impaired its performance since some employment offices are funded from municipal resources and do not regularly report to the MTPS. These efforts are expected to be the first step in a long-term strategy where employment offices provide a range of other services such as specialized training programs, counseling to micro entrepreneurs, and other services. But to reach these goals it needs significant resources: MTPS budget in 2012 amounted for just $\$ 11$ million, 0.05 percent of GDP, among the lowest in the Salvadoran central administration.

Improved monitoring of labor market outcomes is also essential to guide labor market policy interventions. The MTPS aims to create a National Labor Market Observatory (ONML) to strengthen its capacity to analyze and monitor labor market indicators that serve as critical inputs in the formulation of labor market policies. The envisaged ONML would compile and systematize statistical information from MTPS, other government agencies, and the private sector, to enrich the policymaking process of MTPS. These activities would require investment in technological inputs, training of human resources, and improving the coordination channels with the institutions that are responsible for collecting, monitoring, analyzing and producing labor market statistics in a timely and reliable way.

\footnotetext{
32 World Bank (2010).
} 
Despite expanding coverage of vulnerable groups, labor training interventions mostly targets the private sector employed population. INSAFORP administers since 1994 the National Professional Training System (Sistema Nacional de Formacion Profesional, SNFP), which is financed through a 1 percent payroll tax and is managed by a board that has representatives of employers, employees, and the Government. In 2013 its budget reached $\$ 28$ million, equivalent to 0.11 percent of GDP, which is not high in comparison with other Central American countries (Figure 64). The training provision managed by INSAFORP is subcontracted to institutional providers for the actual service delivery. INSAFORP, following its mandate, provides most of its training services through Programa de Formacion Continua, which mostly benefit formal workers in medium-to-large firms. This program consists of training courses (8 to 120 hours) to employees working in firms that contribute to INSAFORP funding, and follows specific training contents proposed by the employer. This program benefits the employed population in the formal sector, which represented 63 percent of total participants in INSAFORP training in 2012-2013. ${ }^{33}$ Around a quarter of Salvadoran firms claim to have used INSAFORP funds at least once to train their labor force. ${ }^{34}$

Figure 64: Spending of Public Training Institutions in Central America as a \% of GDP, 2013

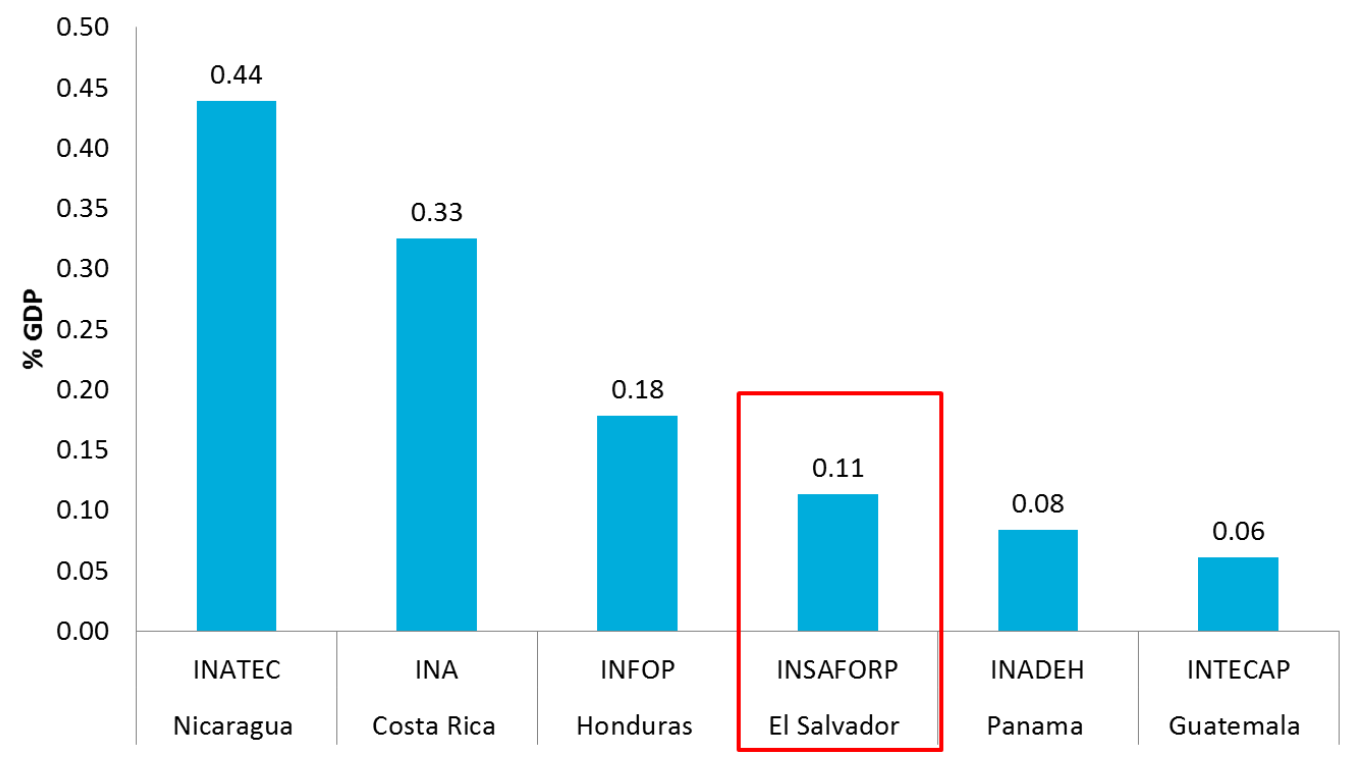

Source: World Bank SSEIR / ICEFI social spending database

Though more recently, INSAFORP has designed training packages targeted to the vulnerable and unemployed population and increase the coverage of this population. Originally, it was not a central objective of INSAFORP to train unemployed or first-time job seekers with low levels of formal education. However, the institution has progressively undertaken reforms to better respond to the needs of the economy and to train these segments of the population. One

\footnotetext{
33 (INSAFORP, 2013).

${ }^{34}$ See Vega and Carranza (2005).
} 
of the recent programs under SNFP is Habilitacion para el Trabajo, which offers short job training courses (between 40 and 260 hours) in 26 different occupations for the unemployed, underemployed and self-employed population (aged 16 or older). There is also a youth modality of Habilitacion para el Trabajo, called Programa Inicial de Modalidad Empresa-Centro, which targets unemployed youngsters between 16 and 25 years old and offer longer courses (between 6 months and 2 years) both in specialized institutions and on the firms. And INSAFORP is also in charge of providing the training package in PATI. In total, in 2012-2013, 37 percent of all beneficiaries in INSAFORP were vulnerable unemployed population (about 83,000 people), up from 25 percent in 2010 (Figure 65). Unfortunately, none of these interventions has been evaluated yet, in terms of quality or employability impact of the training.

Figure 65: Beneficiaries of INSAFORP Training Courses, 2009-2013

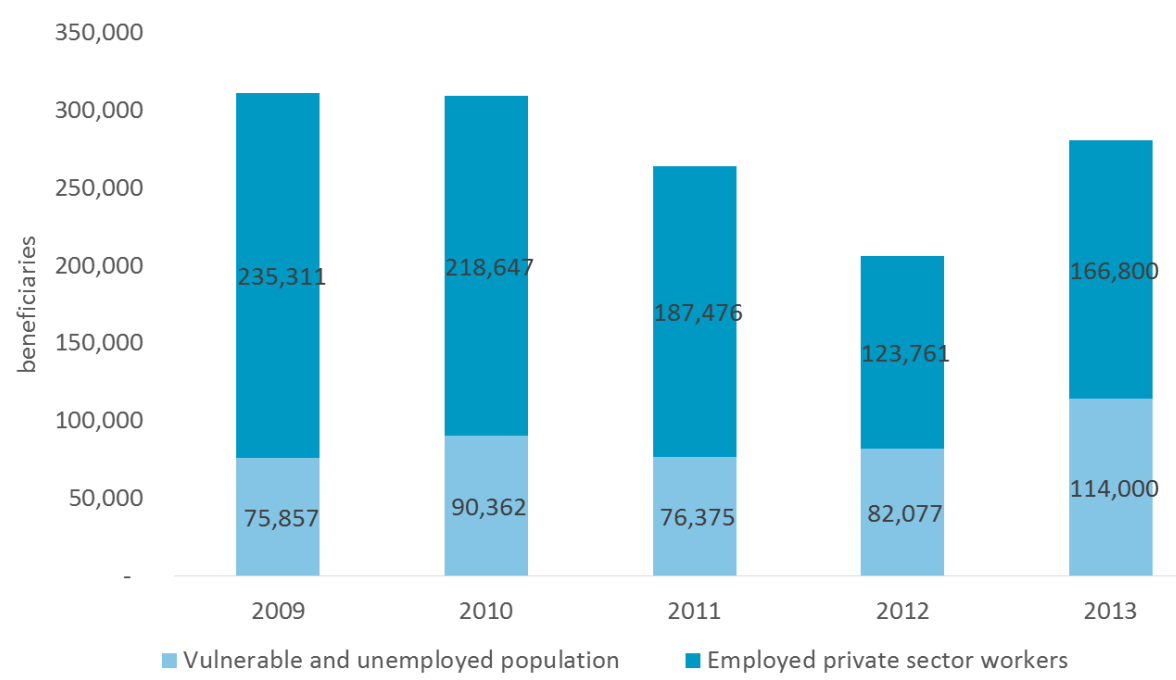

Source: INSAFORP.

\section{V.3 Institutional Reforms and Challenges}

The past Government administration made substantial efforts to build a Universal Social Protection System (SPSU) as part of its National Development Plan. The SPSU is a social policy strategy which the Government has defined in order to achieve the articulation and integration of the social development interventions focusing on a human rights-based approach and the increased participation of local government. It seeks to guarantee the population of El Salvador, especially the poor and extremely poor, a 'basic social level' of well-being through the definition of general and focused policies and programs. The core of the initiative is Comunidades Solidarias, with four areas of intervention: (i) human capital development; (ii) provision of basic public services; (iii) income generation and productive development; and (iv) local governance. Comunidades Solidarias is respectively divided into rural and urban areas, and comprises all major programs (CCT, PATI, Pension Basica Universal, Paquetes Escolares, Paquetes Agricolas, and Alimentacion Ecolar). 
However, the institutional coordination of the SPSU is overly complex. The mandate of the SPSU implies an integral reform concerning the way in which the social development policies of the Government are coordinated, administered and implemented starting with the ruling entities of the Executive Power. However, as of today, the SPSU is implemented through various public institutions under overall coordination of the STP. The lack of champion ministry in charge of defining policy and implement interventions as it happens in other countries ("Ministry of Social Development"), makes this coordination a complex task, impacting in the effective achievement of goals.

Many interventions are implemented in close coordination with subnational entities and active community participation. For the past two decades, the Government has also gradually implemented programs oriented to involve the communities. Community development efforts are supported through the Fund for Social Investment and Local Development (FISDL), which has set the policy for community involvement in development initiatives. Comunidades Solidarias programs also operate through community committees to ensure adequate communication between beneficiary families, their communities and the programs, including the channeling of requests and/or grievances and facilitation of the social audit process.

The Government has recently enacted legislation to protect fiscal space for social sectors and guarantee the permanence of major interventions; however, it needs revisions to become effectively approved and implemented. Congress has recently approved a Law of Social Development, aiming to provide a minimum social protection floor for all the population and protect rights, as stated in the SPSU strategy. However, the new Law does address neither the fiscal angle nor the institutionality needed for its implementation; and a consultation process with all relevant stakeholders has not taken place. The Law also misses the need for continuous monitoring and evaluation of programs, with a focus on improving impact within the fiscal space already gained.

The Government is also creating a registry of beneficiaries of social program that will help to avoid duplication of beneficiaries and target better social interventions. Also, in an attempt to avoid duplication and improve program targeting, in 2009 STP started the development of a national beneficiary registry (Registro Unico de Participantes, RUP). The RUP database will be composed of beneficiaries of most social programs, but the need to develop a comprehensive platform technology, and financial constraints to complete the census database of beneficiary non-beneficiary households through a single registry instrument, has delayed its implementation. The Inter-Sectoral Social Committee has already approved the proxy-means instrument to target social programs through the RUP, and STP has already collected information for 34,000 households in 5 municipalities.

El Salvador is also improving its monitoring and evaluation mechanisms of SPL. The latest administration has not only put effort in creating the RUP, but also in the identification and geographical mapping of interventions, a sustained effort to measure budget allocation of programs (in the absence of program level budgeting at central level), as well as a system to track and follow key management and performance indicators of interventions. Moreover, it has made the evaluation 
of the impact of key interventions a top priority for management, starting with Comunidades Solidarias Rurales, PATI, Paquetes Escolares, and Pension Basica Universal (the last two still pending).

\section{Conclusion and Policy Recommendations}

El Salvador's development over the past decade has been dichotomous. On the one hand, economic growth has remained persistently low, employment and labor force participation have barely increased, and progress on poverty reduction has slowed. On the other hand, inequality has fallen, and shared prosperity improved together with advances - with El Salvador becoming the country with the lowest income inequality in Central America - and in many social indicators have increased, such as pre-primary enrollment rates, access to prenatal care, immunizations, and water and sanitation. Increases and improvements in the use of social spending, which now accounts for 12.4 percent of GDP, explain at least part of this dichotomy of redistributive and social gains despite low growth, a tight fiscal situation and generally low government revenues and spending.

Looking forward, the key challenges facing El Salvador will be to enhance improvements in the quality and efficiency in the social sectors, while holding steady on the overall level of social spending within an increasingly constrained fiscal environment. Although social spending remains relatively low by international standards, further expansions in social spending would not be advisable given fiscal constraints, low revenues, and the need to cut the deficit by 3 percent of GDP. Priority should thus be given to reallocations and improvements within the spending envelope for the social sectors to maximize impact. This review suggests a number of ways El Salvador could reallocate social spending for more effective impacts, enhance and reforms social policies and social service delivery, and improve the management of public spending and budget execution in the social sectors.

\section{VI.1 Education}

Increases in public education spending in El Salvador have improved outcomes for access (higher enrollment) both at the primary and at the secondary level. For instance, El Salvador has reached universal completion in primary education. However, overall spending on education is still low by international standards. In 2012, El Salvador public spending on education accounted for 3.6 percent of the GDP, which is lower than the LAC average (4.9 percent), let alone the OECD average (5.6 percent). In addition, this chapter has discussed that more spending is needed to implement the FTS model nationwide. Furthermore, increases in per-student spending-driven by increases in the number of teachers and teacher salaries-have not yet improved enrollments at upper secondary levels and learning outcomes across the whole system. The key policy question for policymakers in the years ahead is how can the country and its education system increase its low level of spending in the sector in a sustainable manner, while ensuring that the higher levels of 
education receive a greater share of public funds and overall spending increases across all education levels?

Increasing the number and quality of teachers is critical to promote better learning achievements. As analyzed above, learning outcomes are still quite low in El Salvador. Actions are needed both to increase the number of teachers and the quality of instruction. First, and in spite of recent achievements, the student-teacher ratio is still too high compared to good practices. More teachers are needed in order to reduce the student-teacher ratio in traditional subjects but also for new subjects (such as music/art that are part of the FTS model). The speed of the adjustment and the type of teachers required will crucially depend on the forecasts of the demographic trends (as well as available fiscal resources).$^{35}$ Furthermore, to improve teacher quality, teacher recruitment and professional development policies are key. Three areas of intervention have been identified as key for the improvements in teacher quality (Bruns, 2013), and El Salvador should to increase its efforts in at least two of them. First, the need to hire new teachers under the full-time school model provides El Salvador with the unique opportunity to improve teacher quality in the short run through improved recruiting/selection methods. Creating special financial incentives to attract top students into teacher education might have both a direct effect on the quality of the participants and an indirect effect on the social prestige of the profession. Improving the selectivity at entry of the teaching career is another important area of policy intervention, where little efforts have been made so far. Second, better training of the teachers can also have large effects on teacher quality. In this area, the recent efforts made to improve teacher training under the full-time school model suggests that the country is on the right track, as long as the new training model is adequately implemented and brought to scale. Third, motivating teachers with results-based incentives has proven to be an effective way to improve student learning. In El Salvador, teachers' remunerations are currently linked only to their respective tenure in service. Bonus pays would likely produce substantial effects on quality and should thus be further studied and supported.

To reduce dropout rates at the secondary level, there should be a focus both on supply and demand-side measures such as the evaluation/expansion of FTS model and to linking Comunidades Solidarias (CCT) to upper secondary school attendance in urban areas. Over the next decade, the main focus of the sector must be in promoting greater access to secondary education and improved completion rates. On the supply side, priority should be given to the evaluation and expansion of the full-time school model, currently being evaluated both for education outcomes as well as crime and violence in municipalities. The model's sustainability will be critical and the government has already contacted the Bank for support to conduct a financial sustainability exercise. In addition, more efforts should be placed in assessing why children are not completing secondary education. Although high opportunity costs of attending likely play a role, a more thorough diagnostic is needed especially for the most vulnerable groups. On the demand side,

\footnotetext{
35 While reduction in fertility and migration will likely reduce the inflow of student in basic education, the increase in enrollment in upper secondary might boost the demand for that education level.
} 
the Government could consider incorporating secondary-school attendance conditionalities for the CCT. This would make sense since primary school attendance is already very high (near 100 percent), and students start to drop out around age 12 in rural areas and age 14 in urban areas. Since the supply of schools is less of constraint in urban areas (than in rural areas), this conditionality could be piloted and evaluated there first and eventually scaled up once the FTS has reached universal coverage. As it stands, the CCT program currently operates only in rural areas, so the feasibility of both attaching the conditionality of secondary school attendance and expansion to urban areas must be considered. A complementary intervention might be the provision of information about the labor market returns of an upper secondary education.

Improving School Readiness is a key priority in the education sector in El Salvador, yielding improvements in the educational outcomes in the medium and longer term. It is well known that Early Child Development (ECD) is among the most cost-effective policies to foster learning and productivity later in life. Hence, public education spending in El Salvador will only achieve its full potential when placing children's school readiness as a central focus. This can only be done by developing a comprehensive ECD strategy and policy framework. Quality in ECD policies must be a critical concern of policymakers ensuring high quality and motivated teachers, and low studentteacher ratios. In addition, this strategy must be supported by a solid M\&E system and ensure the availability of well-trained home/center-based educators. Also, the country should engage in a gradual introduction of interventions targeted at children in the age group $0-3$ as costs of these policies are potentially very high. The rollout of such a project must be backed by small scale pilots evaluated through rigorous impact evaluation design to allow for testing the cost-effectiveness of alternative strategies (e.g., testing a home-based visits model versus a more hybrid community/home model).

A stronger focus should be placed on the monitoring and evaluation of education policies, producing "real time" information which feeds directly into their design and implementation. El Salvador can rely on rich data but its monitoring and evaluation system still presents gaps. In the short run, it is important to ensure all new policy pilots are tested and evaluated with rigorous empirical strategies (program evaluation). There is also room to strengthen and systematize data collection efforts, including detailed socio-economic characteristics of students/families in the PAES and PAESITA. In particular, a low hanging fruit seems to be ensuring that the school census ("census escolar") and the data sets on learning achievement (PAES and PAESITA) can be uniquely matched in an efficient way. In the medium term, the country should strengthen their systemic approach to monitoring and evaluation in the education system and push for an "open data" approach to better inform beneficiaries of progress. In addition, there is room to ensure that the implementation/decision-making in the Education sector is better informed through data/information collected by a unified M\&E system. Currently, both the lack of relevant training, slow data input lags, disparate M\&E databases, and the system through which the information is provided can help to explain why principals and teachers do not currently use the information obtained through the standardized test scores. 


\section{VI.2 Health}

Despite the financial crisis, public spending on health increased and together with the free health services policy, contributed to improving health coverage, utilization, and outcomes. However challenges remain regarding (1) disparities in access, particularly among the poor and (2) outcomes, particularly in reducing maternal mortality and addressing the increasing threat of noncommunicable diseases. Recent health reforms introduced by the Government such as the Family Community Teams (ECOS) are welcome initiatives to improve access to rural areas although they need to be reviewed to improve their efficiency and sustainability.

In order to address the main challenges identified in the sector, the Government, particularly the Ministry of Health as the steward of the health sector could consider implementing the following recommended short term actions:

Implement the MDG Acceleration Framework (MAF) program. The participation of both public and private institutions providing health care in the country would be essential to the success of the MAP program implementation. The MAF budgetary gap should be estimated based on a complete analysis of the national and donor participation in the targeted areas, and then a strategy to close this budget gap should be prepared and implemented.

Improve budgeting and planning processes. Review existing budgeting and planning process to determine how best to move progressively away from historical planning and budgetary processes to make them more results oriented and efficient

Review the two major health extension programs. The Government should undertake an indepth review of the Integral and Integrated Service Network (RIIS) strategy and the mobile health teams (ECOS) implementation strategy (for example, team size) and allocated budgets to identify concrete ways to improve their efficiency and sustainability

Improve targeting strategies to ensure that public expenditure allocation is well aligned with sector goals. Socioeconomic, Epidemiological analysis and geographical targeting should be taken into account in the allocation of public expenditures on health in the country, taking into consideration the challenges ahead to: reduce neonatal mortality, teen pregnancy and its consequences, control violence and slow the onset of chronic diseases.

Adapt a more preventive approach toward reducing chronic conditions. Formulate a strategy to include chronic conditions in the PHC strategy, particularly on how to incorporate cost effective prevention and health promotion measures.

Initiate steps to address disparities in access to health services based on institutional affiliation. The Ministry of Health could lead the review of the different per capita health expenditures across public institutions and the factors behind these differences and assess the potential for reducing these disparities and moving toward integrating the different institutions providing health care, taking into account institutional and socio-economic constraints. 
In terms of Medium term recommendations (3 to 5 years):

Progressively adopt a results-based budgeting mechanism. Based on its review of the planning and budgeting processes, the sector could move toward a result based allocation mechanism which provides incentives for quality of care. Budgets should be defined based on a complete resource analysis (available and required) to attain realistic outcome targets.

Strengthen implementation of the RISS and ECOS programs. Based on the findings of the review of these two major health expansion programs, the Government should redefine the RIIS and ECOS in order to strengthen their implementation and improve their efficiency and sustainability.

Implement the strategy of incorporating chronic conditions as part of the primary care strategy. Based on the strategy developed, the Government should play an active role in implementing the prevention and management of chronic conditions as part of the primary health care strategy, especially in promoting multi-sectorial interventions that also promote accountability.

Promote a national discussion toward integrating the National Health System. Based on the review (step $\mathrm{f}$ above), the Government could play an active role in promoting a national discussion toward integrating the National Health System, in order to minimize disparities in per capita health expenditures and packages across public sector institutions, as well as to improve coordination of health services and minimize duplication of efforts.

Continue to prioritize MDG-oriented investments especially in priority areas. The Government should continue its efforts to maintain the attention and investment in MDGs, especially in in the MAF targeted municipalities to ensure the availability of the required resources for their development

Develop a multi-sector, multi institution strategy to address violence and its impact on health.

\section{VI.3 Social Protection and Labor}

El Salvador has made important advancements in extending safety nets and increasing SPL spending. The current administration has set the bases for the creation of a universal social protection system (SPSU). This effort has been matched by an expansion of social protection coverage, as well as significant fiscal effort. Today, the country has a range of social assistance, noncontributory pensions, and active labor market programs, meaning that all elements of an integrated social protection system are in place. El Salvador has the largest amount of resources as a share of its economy (GDP) allocated to social assistance and subsidies in the Central American region. A 
question mark given the tight fiscal situation in the country is its sustainability; therefore it is important to focus on making the best use possible of the space gained so far.

One pending reform is on social security, since coverage has not increased much in the last decade, and since the system creates serious deficits that make it unsustainable over the short and medium term. Access to pensions and contributions to its financing is low, at around 20 percent. An attempt to increase coverage among the poor has not succeeded, and the building blocks for a social pension are still at a piloting stage given insufficient funding. More worrisome, the last reform to the contributory system has created important "transition costs" that are now in the order of 2 percent of GDP. The next administration should tackle social security reform as a high priority on fiscal and equity grounds.

Current fiscal constraints make it imperative to reform utility subsidies to reduce leakages to richer families. A universal focus with gradual implementation should be the guiding principle to sustain public social investment, by first reaching out those most in need. Preliminary calculations show that at least 0.66 percent of GDP in social assistance and subsidies benefits the upper quintiles of the income distribution. Most of this spending in concentrated in untargeted and ineffective electricity and gas subsidies, and as such could be reallocated to other priority areas and groups. A simple reform that excludes from subsidies those consuming between 100 and $200 \mathrm{kWh}$ of electricity would save 0.45 percent of GDP. It is thus crucial to determine which programs deserve broader coverage and identify resources that could be reallocated from programs with limited impact.

It is thus important to focus efforts on expanding social assistance programs that reach most needed population and with demonstrated impact on human development outcomes. The rural CCT that has proven a successful mechanism to tackle poverty and has helped close gaps in education and health outcomes should be reformed and revamped. In the last few years, due to insufficient funding, its coverage (already low per international standards) has declined. A new reform would revise benefits, conditionalities (with a focus on completion of lower and upper secondary school), and an expansion to urban areas where many of the poor live. The PATI program is another candidate for expansion. It is important to continue this intervention that provides opportunities for income and human capital development for the poor, while at the same time stimulates economic activity at the local level. Nevertheless, to improve its performance and respond to new emerging needs, it could consider: a) a longer-term horizon of support to beneficiaries to improve labor market insertion, through complementary technical training or credit support to stimulate new businesses; b) mentoring or provision of life-skills training to reduce violence in neighborhoods; and c) emphasizing targeting on the youth..

Coverage of ALMPs is low, and more efforts are needed to reach the most vulnerable population. Despite the last few years the income for the low skilled population increased, these gains may be short lived and vulnerable to shocks. There are still few mechanisms to protect the most vulnerable against the loss of labor income. Experiences like PATI are promising, but need to be complemented with appropriate interventions to improve human capital, productivity, and better 
skills match with local employment opportunities to ensure sustained income generation of the vulnerable population. In general, ALMP operate on a very small scale (there is no national youth employment program, as in other countries), and resources in strengthening employment offices for labor intermediation and orientation are insufficient. It is critical to revise and refocus the employment service mechanism offered by RNE to better serve the poor and low-skilled unemployed in search of work opportunities, including self-employment promotion and mentoring activities.

The current institutional setting for the occupational training system provides little information on the quality and adequacy of existing training programs, limiting the efforts of better matching existing skills and those needed in the market. There are important resources allocated to training (INSAFORP), but the majority of courses benefits high skilled employed population. The role of INSAFORP and other training institutions should be reassessed and independently evaluated. Among other things, it is necessary to: a) review of the legal, regulatory, and normative rules governing the professional training system, including the accreditation of service providers and the quality of service provision; b) review of the financing framework, including an analysis of costs by type of service provider, courses and sources of funding; and c) assess the modalities to help graduates enter the labor market, including partnerships between training institutions and the private sector (e.g., apprenticeship: school-based, and workbased learning), and the information available to training institutions on labor market needs; d) develop programs that address training needs of those who intend to be self-employed; and e) improve the coordination within the occupational training system and with upper secondary education.

It is also critical to continue the efforts in monitoring and evaluation of programs, as well as in investing in information systems to better target beneficiaries. The current administration has set as a high priority the development of a system to track indicators in the social sector that can guide in the future the planning and budgeting process. It has also emphasized the need of periodical evaluations of programs, to make corrections as needed. These efforts should be continued in the next administration. Another high priority is the finalization of the RUP that would help eliminate unnecessary duplications of benefits and improving targeting towards the poor. This would require additional resources to finalize the data collection and technology platform, as well as a mandated commitment on its use by different agencies executing programs.

Improvement in implementation and coordination among institutions is also essential to maximize the impact of interventions. Successful implementation of SPL systems depends not only on the design of individual programs, but creating institutional mechanisms for policy formulation. Interventions to similar targeted population groups should be delivered in "service packages", to exploit complementarities, synergies and economies of scale in service delivery. This represents a challenge in terms of inter-institutional dialogue across the different ministries and implementing units. The ultimate goal is to integrate these policies into a common social protection strategy. The next Government administration could focus on institutional reform and legislation to 
guide spending priorities and enhance coordination. Enhanced implementation requires deep reflection on the fragmentation of programs and their financing.

Legislation can help to protect gains in expanding SPL, but it needs to be flexible enough to adapt to changing needs, reflect fiscal realities, and generate consensus. A new Law of Social Development has been approved by Congress. This piece of legislation is a high pay-off investment needed to ensure sound implementation of medium-term reforms of the social sector spending. But while the current version of the Law aims at protecting investments in the sector, it does not give room for evidence-based periodical adjustments of interventions and implementation performance (e.g., by mandating the use of RUP). It is also important to generate a broader consensus from all political parties in the country, to guarantee continuity. 
El Salvador Social Expenditure and Institutional Review

\section{Annex}

\begin{tabular}{|c|c|c|}
\hline $\begin{array}{l}\text { Options for } \\
\text { Policy Reform }\end{array}$ & Short term (1-2 years) & Medium term (3-5 years) \\
\hline \multicolumn{3}{|l|}{ Education } \\
\hline ECD policy & 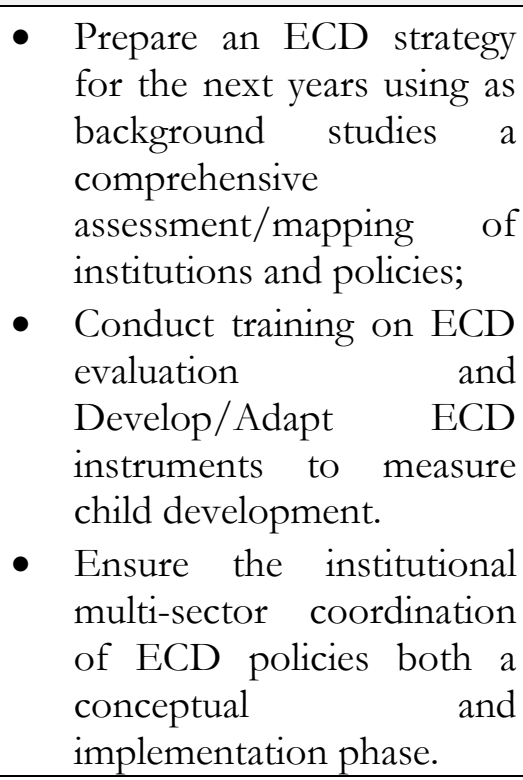 & $\begin{array}{l}\text { - Identify service gaps and pilot } \\
\text { alternative interventions aimed } \\
\text { at supporting child developed 0- } \\
6 \text { years old (for instance home } \\
\text { vs. community based programs) } \\
\text { - Gradual scale-up of the most } \\
\text { cost effective interventions } \\
\text { - Development and enforcement } \\
\text { of quality standards }\end{array}$ \\
\hline $\begin{array}{l}\text { Increase in the } \\
\text { enrollment in } \\
\text { upper-secondary } \\
\text { school }\end{array}$ & 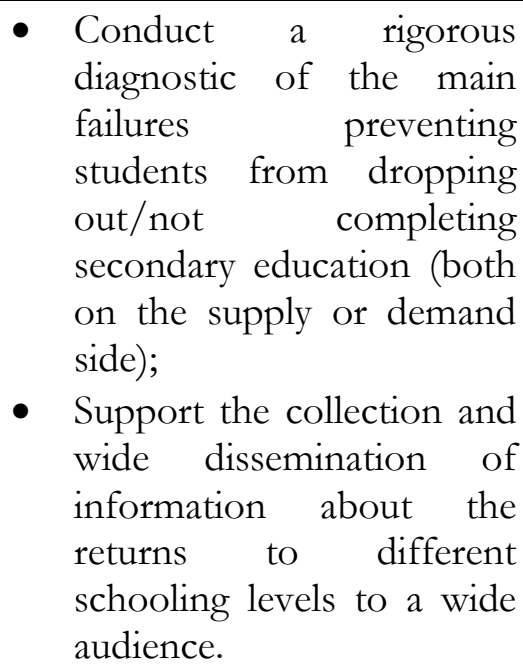 & $\begin{array}{l}\text { - Support the development of } \\
\text { comprehensive policies } \\
\text { addressing drop-out rates } \\
\text { especially for at risk groups. } \\
\text { - Eventual redesign of the FTS } \\
\text { model based on the findings } \\
\text { from the evaluation studies. } \\
\text { - Including attendance to upper } \\
\text { secondary education as a } \\
\text { conditionality in Comunidades } \\
\text { Solidarias }\end{array}$ \\
\hline
\end{tabular}




\begin{tabular}{|c|c|c|}
\hline $\begin{array}{l}\text { Increase } \\
\text { number } \\
\text { quality } \\
\text { teachers }\end{array}$ & $\begin{array}{l}\text { - Develop a realistic and fiscally } \\
\text { sustainable hiring plan to } \\
\text { address teacher shortages (given } \\
\text { the FTS model }+ \text { targets for } \\
\text { enrolment rates }+ \text { student- } \\
\text { teacher ratios) } \\
\text { - To improve the recruitment and } \\
\text { motivation of teachers, establish } \\
\text { financial incentives for top } \\
\text { performing students to become } \\
\text { teachers, contributing to } \\
\text { increase the social prestige of } \\
\text { the profession }\end{array}$ & $\begin{array}{l}\text { - Sustainably increase the number } \\
\text { of teachers in upper secondary } \\
\text { education in order to meet } \\
\text { international reference for } \\
\text { student-teacher ratios } \\
\text { - Raising accreditation standards } \\
\text { for university based programs to } \\
\text { increase the quality of teacher } \\
\text { training. } \\
\text { - Introduce well-defined career } \\
\text { progression and financial } \\
\text { rewards linking career } \\
\text { progression with performance } \\
\text { and training. }\end{array}$ \\
\hline $\begin{array}{l}\text { Strengthen and } \\
\text { Institutionalize } \\
\text { a Monitoring } \\
\text { and evaluation } \\
\text { system in the } \\
\text { Education } \\
\text { Sector }\end{array}$ & $\begin{array}{l}\text { - Ensure all new policy pilots are } \\
\text { tested and evaluated with } \\
\text { rigorous empirical strategies } \\
\text { (program evaluation); } \\
\text { - Strengthen and systematize data } \\
\text { collection efforts, including } \\
\text { detailed socio-economic } \\
\text { characteristics } \\
\text { students/families in the PAES } \\
\text { and PAESITA; } \\
\text { - Ensure the census escolar and } \\
\text { the PAES and PAESITA can be } \\
\text { uniquely matched in an efficient } \\
\text { way. }\end{array}$ & $\begin{array}{l}\text { - Develop a systemic approach to } \\
\text { monitoring and evaluation in the } \\
\text { education system through a } \\
\text { unified system of data; } \\
\text { - Provide a platform for greater } \\
\text { data transparency or "open data" } \\
\text { as well as responsive, just-in- } \\
\text { time data to inform stakeholders } \\
\text { and decision-makers; } \\
\text { - Ensure } \\
\text { implementation/decision } \\
\text { making on the Education sector } \\
\text { is well informed regarding } \\
\text { data/information collected by } \\
\text { the M\&E system. }\end{array}$ \\
\hline \multicolumn{3}{|l|}{ Health } \\
\hline $\begin{array}{l}\text { Better targeting } \\
\text { of interventions }\end{array}$ & $\begin{array}{l}\text { - Invest in the High Risk MDG5 } \\
\text { MAF municipalities } \\
\text { implementing a coherent } \\
\text { investment plan for the next } 18 \\
\text { months } \\
\text { - Ensure that the free health care } \\
\text { policy benefits lower quintiles of } \\
\text { income }\end{array}$ & $\begin{array}{l}\text { - Maintain the attention and } \\
\text { investment in the targeted } \\
\text { municipalities beyond the MAF } \\
\text {-MDG time line ensuring the } \\
\text { commitment for their } \\
\text { development } \\
\text { - Implement better targeted } \\
\text { policies/strategies }\end{array}$ \\
\hline
\end{tabular}




\begin{tabular}{|c|c|c|}
\hline $\begin{array}{l}\text { Prioritize cost } \\
\text { effective } \\
\text { preventive } \\
\text { interventions }\end{array}$ & $\begin{array}{l}\text { - Evaluate RIIS and ECOS } \\
\text { performance and its } \\
\text { sustainability } \\
\text { - Develop a strategy to } \\
\text { incorporate non-communicable } \\
\text { disease in the PHC program. } \\
\text { - Evaluate the overlapping of } \\
\text { services of the major } \\
\text { institutions health providing } \\
\text { health care. }\end{array}$ & $\begin{array}{l}\text { - Redefine the RIIS-ECOS } \\
\text { elements and strengthen their } \\
\text { implementation } \\
\text { - Implement the NCD strategy } \\
\text { within the PHC program } \\
\text { - Review MOH-ISSS Agreement } \\
\text { implementation } \\
\text { - Propose a way forward on the } \\
\text { integration of the National } \\
\text { Health System. }\end{array}$ \\
\hline $\begin{array}{l}\text { Improve } \\
\text { efficiency } \\
\text { sector } \\
\text { expenditures }\end{array}$ & $\begin{array}{l}\text { - Review budget allocation } \\
\text { process. } \\
\text { - Take the lead in reviewing } \\
\text { disparities in service packages } \\
\text { and per capita spending across } \\
\text { health institutions, assessing the } \\
\text { feasibility of reducing these } \\
\text { differences taking into account } \\
\text { political economy and socio- } \\
\text { economic factors. }\end{array}$ & $\begin{array}{l}\text { - Gradually move away from } \\
\text { historical budgeting toward } \\
\text { implementing a results-based } \\
\text { budgeting and management } \\
\text { system. } \\
\text { - Promote a national discussion to } \\
\text { move toward aligning the } \\
\text { package of health services } \\
\text { provided by various public } \\
\text { institutions to minimize } \\
\text { disparities in per capita } \\
\text { expenditures and services } \\
\text { provided. }\end{array}$ \\
\hline \multicolumn{3}{|l|}{ Social Protection } \\
\hline $\begin{array}{l}\text { Consolidate SPL } \\
\text { interventions }\end{array}$ & $\begin{array}{l}\text { - Reform SPL institutional sector } \\
\text { for better accountability and } \\
\text { coordination. } \\
\text { - Approved with broad } \\
\text { consensus a Law of Social } \\
\text { Development } \\
\text { - Finalize construction of RUP }\end{array}$ & $\begin{array}{l}\text { - Fiscal and subsidy reform } \\
\text { - Reform social security (revise } \\
\text { financing of contributory } \\
\text { system, incentivize coverage } \\
\text { expansion). }\end{array}$ \\
\hline
\end{tabular}


El Salvador Social Expenditure and Institutional Review

\begin{tabular}{|c|c|c|}
\hline $\begin{array}{l}\text { Improve } \\
\text { effectiveness of } \\
\text { Social } \\
\text { Assistance } \\
\text { interventions }\end{array}$ & $\begin{array}{l}\text { - Revise conditionalities of CCT } \\
\text { program } \\
\text { - Expand PATI to new coverage } \\
\text { areas and complement it with } \\
\text { associated interventions for } \\
\text { improved employability }\end{array}$ & $\begin{array}{l}\text { - Expand CCT program to urban } \\
\text { areas } \\
\text { - Continue investing in impact } \\
\text { evaluations to periodically assess } \\
\text { program performance and } \\
\text { indicators }\end{array}$ \\
\hline $\begin{array}{l}\text { Revamp Labor } \\
\text { Market Policies } \\
\text { and Training } \\
\text { Programs }\end{array}$ & $\begin{array}{l}\text { - Expand coverage of } \\
\text { employment services with } \\
\text { public-private arrangements } \\
\text { and with municipalities } \\
\text { - Consider implementing specific } \\
\text { ALMPs (such as youth } \\
\text { employment programs) }\end{array}$ & $\begin{array}{l}\text { - Reform INSAFORP to increase } \\
\text { incentives to train unemployed } \\
\text { youth } \\
\text { - Evaluate performance of } \\
\text { training institutions in light of } \\
\text { labor market needs. }\end{array}$ \\
\hline
\end{tabular}


El Salvador Social Expenditure and Institutional Review

\section{Bibliography}

Afonso, A., Romero, A., \& Monsalve, E. (2013). Public Sector Efficiency: Evidence for Latin America. Washington, DC: Inter American Development Bank.

Afonso, A., Schuknecht, L., \& Tanzi, V. (2005). Public sector efficiency: An international Comparison. Public Choice, 123 (3), 321-347.

Afonso, A., Schuknecht, L., \& Tanzi, V. (2010). Public Sector Efficiency: Evidence for New EU Member States and Emerging Markets. Applied Economics, 42 (17), 2147-2164.

Almeida, Fitzimons, \& Rogers. (2014). How to prevent secondary-school dropout: Evidence from rigorous evaluations. Washington, DC: World Bank Mimeo.

Artana, D., \& and Navajas, F. (2008). Analisis y rediseño de los subsidios en El Salvador. Buenos Aires: Fundacion de Invetigaciones Economicas Latinoamericanas.

Avitabile, C., \& Hoyos, R. D. (2014). The Heterogenous Effect of Information about School Returns: Evidence from a Randomized Experiment in Mexico. Washington, DC: World Bank. Mimeo.

Beneke de Sanfeliu, M., \& Acosta, P. (2014). Programa de Apoyo Temporal al Ingreso (PATI): Evaluacion de Impacto.

Bruns, B., \& Javier, L. (2014). Great Teachers: How to Raise Student Learning in Latin America and the Caribbean. Washington, DC: World Bank.

Calvo-Gonzalez, O., Cunha, B., \& Trezzi, R. (2014). When winners feel like losers.

Chetty, R., Friedman, J. N., \& Rockoff, J. E. (2013). Measuring the Impacts of Teachers I: Evaluating Bias in Teacher Value-Added Estimates. NBER Working Papers, 19423.

Chetty, R., Friedman, J. N., Hilger, N., Saez, E., Schanzenbach, D. W., \& Yagan, D. (2011). How Does Your Kindergarten Classroom Affect Your Earnings? Evidence from Project Star. Journal of Economics, Oxford University Press, vol. 126(4), pages 1593-1660.

Clements, B., Gupta, S., Karpowicz, I., \& Tareq, S. (2010). Evaluating Government Employment and Compensation. Washington, DC.: Fiscal Affairs Department. International Monetary Fund.

Coelli, T., Rao, P., \& Battese, G. (2005). An Introduction to Efficiency and Productivity Analysis. Boston: Kluwer.

Farrell, M. (1957). The Measurement of Productive Efficiency. Journal of the Royal Statistical Society, Series A, 120, Part 3, 253-290.

FUSADES and IFPRI. (2010). Evaluacion Externa del Programa Red Solidaria: Informe de Impactos a los Dos Años de Implementacion. San Salvador: International Food Policy Research Institute (IFPRI) y Fundación Salvadoreña para el Desarrollo Economico y Social (FUSADES).

Gasparini, L., Galiani, S., Cruces, G., \& Acosta, P. (2011). Educational Upgrading and Returns to Skills in Latin America: Evidence from a Supply-Demand Framework, 1990-2010. World Bank Policy Research Working Paper, No. 5921.

INSAFORP. (2013). Informe de Rendicion de Cuentas: Junio 2012 - Mayo 2013. El Salvador: Instituto Salvadoreño de Formacion Profesional.

International Monetary Fund (IMF). (2013). El Salvador Article IV. Washington, DC: IMF Country Report No. 13/132 .

Jimenes, E., \& Sawada, Y. (2014). Does Community Management Help Keep Children in Schools; Evidence Using Panel Data from El Salvador's EDUCO Program. Economic Development and Cultural Change, University of Chicago Press, vol. 62(2), pages 307-338.

Ministerio de Salud Publica. (2013). Informes de Labores 2012-2013. El Salvador: Ministerio de Salud Publica.

Ministerio de Salud Publica y Asistencia Social. (2012). Diagnostico Nacional de Salud. Guatemala: Ministerio de Salud Publica y Asistencia Social. 
Ministerio de Salud Publica y Sistema de Naciones Unidas de El Salvador. (2013). Marco de Aceleración de los ODM. Condiciones de Exito para el Logro de las Metas de la Mortalidad Materna e Infantil (ODM 4 Y 5). El Salvador: Ministerio de Salud Publica y Sistema de Naciones Unidas de El Salvador.

Patrinos, H. A., Velez, E., \& Wang, C. Y. (2013). Framework for the Reform of Education Systems and Planning for Quality. Policy Research Working Paper, The World Bank, Series 6701.

Pineda, J. M. (2013). Centroamerica Gasto Social y la Revision de sus Insituciones: Inversiones Inteligentes en Desarrollo Humano, Sector Salud: El Cado de El Salvador. El Salvador: World Bank, Mimeo.

Rofman, R., Apella, I., \& Vezza, E. (2015). Beyond Contributory Pensions : Fourteen Experiences with Coverage Expansion in Latin America. Washington, DC: World Bank.

Thanassoulis, E. (2001). Introduction to the Theory and Application of Data Envelopment Analysis. Boston: Kluwer.

Vega, L., \& M, C. (2005). El Salvador: Experiencias y Vision de lso Empresarios sobre la Insercion Laboral de los Jovenes. San Salvador: Universidad Centroamericana Jose Simeon Canas.

Vegas, E., \& Umansky, I. (2005). Improving Teaching and Leaning Through Effective Incentives: What Can We Learn from Education Reforms in Latin America? World Bank Other Operational Studies, 8694.

WHO. (2010). Country Cooperation Strategy at a Glance: El Salvador. World Health Organization.

WHO, UNICEF, UNFPA, The World Bank and the United Nations Population Division. (2014). Trends in Maternal Mortality: 1990 to 2013. Switzerland: World Health Organization .

World Bank. (2004). El Salvador - Public Expenditure Review. Washington, DC: World Bank.

World Bank. (2005). Central America Education Strategy: An Agenda for Action. Washington, DC: World Bank.

World Bank. (2010a). Mas y Mejores Empleos en El Salvador. Washington, DC: World Bank. World Bank. (2010b). El Salvador-Public Expenditure Review. Washington, DC: World Bank. World Bank. (2014). El Salvador: Fiscal Policy Options. Washington, DC: World Bank. 